\title{
Use of weaning diets in \\ combined feeding of females \\ and young rabbits
}

Ph.D. Thesis
Beatriz Martínez Vallespín

Supervisors

Dr. Enrique Blas Ferrer

Dr. Juan José Pascual Amorós

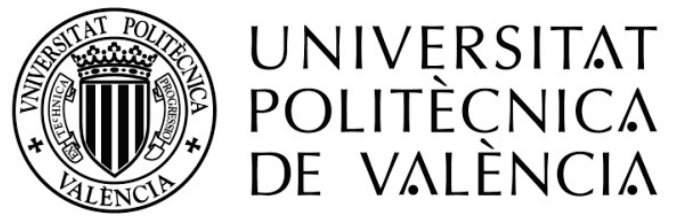

Departamento de Ciencia Animal

December 2011 

La ciencia avanza a pasos, no a saltos. 

A los que no han podido

llegar a ver esto 



\section{AGRADECIMIENTOS}

Son muchas las personas a las que tengo que agradecer el que yo haga llegado hasta aquí.

En primer lugar a mis padres que en todo momento han estado apoyándome, ayudándome y aconsejándome. Me habéis hecho sentir que estáis orgullosos del rumbo que decidí tomar. A mi hermana y a Javi por estar ahí siempre y porque en estos años fuera de Zaragoza me he dado cuenta de lo importante que es para mí tener cerca a la familia. Y, cómo no, al último en llegar, Alberto, el niño más encantador del mundo (y lo digo objetivamente, no porque yo sea su tía), porque con una sonrisa te alegra el día, y por la ilusión que muestra al descubrir el mundo; porque has sido el que nos has hecho más llevaderos los momentos más duros.

A Toni, por la paciencia infinita que tienes conmigo, por tu cariño, tu apoyo y tu ayuda en tantas y tantas cosas; porque consigues que la distancia geográfica parezca más corta.

A Enrique, por todo el tiempo que me has dedicado y por todo lo que he aprendido de ti. No sólo has actuado como mi director de tesis sino también como alguien que se ha preocupado de mí, más allá del tema académico, en los cuatro años que he estado en Valencia.

A Juanjo por las brillantes ideas que llegaban cuando estábamos al borde del "suicidio" y por tu gran ayuda en los temas estadísticos.

A Concha que consigue que la organización de los experimentos en la granja parezca sencilla y los millones de datos recogidos tengan "milagrosamente" un orden y un sentido.

A Luis y Eugenio por hacer las innumerables horas en granja y en laboratorio (y alguna tomando almorzando) mucho más llevaderas. A Juan Carlos, por tu don con el bricolaje y porque gracias a ti la granja funciona. A Javi por tu ayuda y tu paciencia conmigo en el laboratorio. A Águeda por todas las veces que me has "salvado la vida" cuando estaba a punto de tirar el 
ordenador por la ventana, por tu ayuda con los papeleos $y$, sobre todo, por todo el tiempo que has perdido intentando explicarle a una "aficionada" cómo maquetar su tesis. A $\mathrm{M}^{\mathrm{a}}$ Carmen (mi primera compañera de despacho) por todas las charlas que me han ayudado a desconectar en momentos de cansancio. A Carlos por su ayuda, entre otras cosas, en mis primeras incursiones en la docencia. A Sergio, por su apoyo desde el principio y por su ayuda con el primer experimento, y a Jordi por la suya con el segundo. A Davi, Orlando y Gilbert por el buen ambiente que hay ahora en el despacho.

A David y Rosa por ser tan buenos amigos; por hacer que no me sintiera sola en Valencia, por ayudarme en miles de cosas, por acompañarme sin preguntar dónde y por estar siempre disponibles ante una llamada de teléfono. Bueno, y vale, lo admito, por aguantar mis cambios de humor repentinos. A Vicen por tu ayuda en los muchos aspectos relacionados con la informática que yo no controlaba, por tu intento de socializarme un poco en Valencia (con un éxito más bien discreto) y, por supuesto, por tus pasteles ( $y$ bombones, mazapanes...) que han endulzado tantos momentos buenos y malos. A Pati y a Vic por todos los ratos pasados desde ese hoy lejano "grupo de comidas". Me ha dado fuerzas en este último tramo el ver por Pati que al final las cosas salen bien. Ha sido un gran apoyo el compartir nuestro final de tesis. A las supernenas (ahora ya son 4), porque no sé cómo lo consiguen pero siempre están de buen humor y se lo transmiten a los demás. A Mamen por su compañía en el mundo de las "maris" (y a Fer, que no me olvido de ti). Y junto a ellos, a Tamara, lón, Silvia I y II, Ilaria (y su ayuda con el italiano), Rosa, Pablo, Jorge, Javi, Noe, Fede, Raquel (espero no haberme dejado a nadie) por todos los días de buceo, paellas, torrás, voley, excursiones, pádel... y por hacerme sentir parte de esta gran "familia" que es el departamento de Ciencia Animal.

A Dani, Patri y Yoli que fuisteis mis primeros apoyos en Valencia, por los ratos felices en Caravaca 18.

A Manolo Fondevila, Quim Balcells, Leticia y Norelys que me acogisteis tan bien en mi regreso (aunque temporal) a la Faculta de Veterinaria de Zaragoza. 
Grazie anche al Proffesore Boiti, a Margherita, Lorena, Gabrielle, Laura e Celeste per la sua calida acoglienza e il suo aiuto in quelli mesi che ho pasato a l'Università di Perugia. Anche a Francesco, Gabrielle, "il grescio" (il migliore barman dalla Italia) e tutta la gente così diversa che si riuniva ogni sera al Caffe del Banco per tutte le birre che abbiamo compartito e che hanno fatto i miei giorni a Perugia tanto speciali.

Thanks to George Grant, Michelle, Jody, Norma and Catherine for their help and for considering me as one of them, for all that they taught to me and also for being so patient with my English. Since my stay in the Rowett Institute I fell in love with Scotland, and it is not only because of the beauty of the country, but also because of the people I met there. $Y$ hablando de todos a los que conocí en Escocia, tengo mucho que agradecer a nuestro pequeño grupo español. Cristina, Eva, Lush y Mireia, sin vosotras nada habría sido igual en esos fríos meses en Aberdeen. Finally, but not because it is less important, to Joanna, for being so good housemate and friend, and for avoid me exploding in some "difficult" situations.

A Andrea, Caro, Eva y Leticia por vuestra amistad y porque, a pesar de los cada vez más espaciados encuentros, cuando estamos juntas parece que no haya pasado el tiempo.

A todos los de Veterinaria porque, aunque he estado desconectada durante tanto tiempo, al menos una vez al año, cuando nos reunimos por Navidad, me siento como si aún estuviera en aquellos felices años de Universidad.

A María por hacerme sentir uno más del grupo desde el primer día que os conocí, por todos los esfuerzos y la ilusión que pones en que, a pesar de la distancia nos podamos reunir. A Pablo y Miguel por los días de turismo/tabernas que hemos compartido. ¡Ah! y Pablo, gracias por tu inestimable ayuda en el diseño de la tesis; jeres un artista!.

A todos vosotros, ¡muchas gracias! 



\section{ABSTRACT}

This thesis tackles the design of new feeding strategies in the present situation of rabbit production, marked by a high prevalence of Epizootic Rabbit Enteropathy and the systematic use of antibiotics as the usual way to maintain digestive health of growing rabbits and, consequently, the economic viability of the rabbit farms. In this context, the work has been focused in the use of weaning diets in combined feeding of rabbit does and litters.

In a first experiment, eight weaning diets were formulated according to a factorial design $2 \times 2 \times 2$, the factors being: i) the partial replacement of starch with acid detergent fibre, ii) the partial replacement of starch with neutral detergent soluble fibre and iii) the reduction of crude protein content. The experimental diets were administrated to the rabbit does and their litters from $17^{\text {th }}$ day of lactation to weaning at 28 days; after weaning, young rabbits continued receiving the experimental diets until 49 days when they were switched to a commercial growing diet until 60 days. In general, the dietary changes under study affected negatively milk yield and body condition of rabbit does at weaning, as well as litter weight at weaning. However, these changes reduced the mortality rate in young rabbits after weaning, showing additive effects.

In a second experiment, the effect of the eight previous diets on caecal environment of growing rabbits was studied. Samples were obtained from animals slaughtered at 35 days of age, which were receiving one of the eight experimental diets from $17^{\text {th }}$ day and were weaned at 28 days. The dietary changes mainly affected the caecal concentration of volatile fatty acids (by increasing) or/and of ammonia (by decreasing), establishing a more favorable environment to maintain the stability of the caecal microbial ecosystem and, consequently, the digestive health which would explain the reduction in mortality rate observed in the previous experiment.

In the third experiment, the long term effects of a feeding system based in the use of a less concentrated weaning diet (shown as beneficial to 
digestive health of growing rabbits according to the results obtained in the previous experiments) and of an extensive reproductive system (insemination at 25 days and weaning at 42 days) were studied with a factorial design $2 \times 2$, by comparing with the conventional feeding system and the semi-intensive reproduction system (insemination at 11 days and weaning at 28 days) during five productive cycles. As in the first experiment, the weaning diet was administrated from $17^{\text {th }}$ day of lactation to weaning in the case of rabbit does and to 49 days in the case of young rabbits. The feeding system based in the use of a less concentrated weaning diet and the extensive reproductive system led to several negative effects through the successive cycles (lower milk yield, lower live weight of rabbit does, lower litter weight at birth, lower weight of young rabbits at weaning), revealing an adaptation process of rabbit does to both limited availability of resources and higher physiological effort because of longer lactations. On the contrary, both strategies decreased mortality rate of growing rabbits.

To summarize, the results of this thesis show that both the use of less concentrated weaning diets and the delay of the weaning age impaired the performance of rabbit does and reduced the mortality rate of growing rabbits in a context of Epizootic Rabbit Enteropathy. Nevertheless, even considering this reduction, the registered mortality rates were clearly higher to the acceptable ones in a rational and viable rabbit production system. 


\section{RESUMEN}

En esta tesis se aborda el diseño de nuevas estrategias de alimentación en el contexto actual de la producción cunícola, marcado por una alta prevalencia de Enteropatía Epizoótica del Conejo y la utilización de antibióticos como forma habitual de mantener la salud digestiva de los gazapos en crecimiento $y$, consecuentemente, la viabilidad económica de las explotaciones. En este marco, el trabajo se ha centrado en la utilización de piensos peri-destete en alimentación conjunta de conejas y camadas.

En un primer experimento, se formularon ocho piensos peri-destete de acuerdo a un diseño factorial $2 \times 2 \times 2$, siendo los factores: i) la sustitución parcial de almidón por fibra ácido detergente, ii) la sustitución parcial de almidón por fibra soluble en detergente neutro y iii) la reducción del contenido en proteína bruta. Los piensos experimentales se administraron a las conejas y sus camadas desde el día 17 de lactación hasta el destete, que se produjo a los 28 días; tras el destete, los gazapos continuaron recibiendo los piensos experimentales hasta los 49 días, pasando a consumir después un pienso comercial de cebo hasta los 60 días. En general, las variaciones dietarias estudiadas afectaron negativamente a la producción lechera y la condición corporal de las conejas al destete, así como al peso de las camadas al destete. Sin embargo, tales cambios redujeron la mortalidad de los gazapos en post-destete, con efectos que fueron aditivos.

En un segundo experimento, se estudió el efecto de los ocho piensos anteriores sobre el ambiente cecal de los gazapos en crecimiento. Se utilizaron muestras de animales sacrificados a los 35 días de edad, que estuvieron recibiendo uno de los ocho piensos experimentales desde el día 17 y se destetaron a los 28 días. Las modificaciones dietarias afectaron principalmente a la concentración cecal de ácidos grasos volátiles (incrementándola) o/y de amoniaco (disminuyéndola), creando un ambiente más favorable para el mantenimiento de la estabilidad del ecosistema microbiano cecal y por tanto de la salud digestiva, que explicaría la reducción de la mortalidad observada en el experimento anterior. 
En el tercer experimento, se estudiaron los efectos a largo plazo de un sistema de alimentación basado en el empleo de un pienso peri-destete de baja concentración nutritiva (favorable para la salud digestiva de los gazapos según los resultados de los experimentos anteriores) y de un sistema reproductivo extensivo (inseminación a 25 días y destete a 42 días), mediante un diseño factorial $2 \times 2$, comparándolos con el sistema de alimentación convencional y con el sistema reproductivo semi-intensivo (inseminación a 11 días y destete a 28 días) durante cinco ciclos productivos. Como en el primer experimento, el pienso peri-destete se administró desde el día 17 de lactación hasta el destete en el caso de las conejas y hasta el día 49 en el caso de los gazapos. El sistema de alimentación basado en el pienso peri-destete de baja concentración nutritiva y el sistema reproductivo extensivo dieron lugar a distintos efectos negativos a lo largo de los diferentes ciclos productivos (menor producción lechera, menor peso de las conejas, menor peso de las camadas al parto, menor peso de los gazapos al destete), poniendo de manifiesto un proceso de adaptación de las conejas a la disponibilidad limitada de recursos y al mayor esfuerzo fisiológico debido a lactaciones más largas. Por el contrario, ambas estrategias redujeron la mortalidad de los conejos en crecimiento.

En resumen, los resultados de esta tesis indican que tanto el empleo de piensos peri-destete de baja concentración nutritiva como el retraso de la edad al destete penalizan el rendimiento de las conejas y reducen la mortalidad de los gazapos en crecimiento en un contexto de Enteropatía Epizoótica del Conejo. No obstante, incluso considerando tal reducción, las tasas de mortalidad registradas fueron claramente superiores a las aceptables en un sistema de producción cunícola racional y viable. 


\section{RESUM}

En aquesta tesi s'empren el disseny de noves estratègies d'alimentació en el context actual de la producció cunícola, marcat per una alta prevalença d'Enteropatia Epizoòtica del Conill i la utilització d'antibiòtics de com a forma habitual de mantenir la salut digestiva dels llorigons en creixement $i$, conseqüentment, la viabilitat econòmica de les explotacions. En aquest marc, el treball s'ha centrat en la utilització de pinsos peri-deslletament en alimentació conjunta de conilles i ventrades.

En un primer experiment, es van formular vuit pinsos peri-deslletament d'acord a un disseny factorial $2 \times 2 \times 2$, on els factors foren: i) la substitució parcial del midó per fibra àcid detergent, ii) la substitució parcial del midó per fibra soluble en detergent neutre i iii) la reducció del contingut en proteïna bruta. Els pinsos experimentals es van administrar a les conilles $i$ les seues ventrades des del dia 17 de lactació fins al deslletament, que es va produir als 28 dies; després del deslletament, els llorigons van continuar rebent els pinsos experimentals fins als 49 dies, passant a consumir després un pinso comercial d'engreixament fins als 60 dies. En general, les esmentades variacions en la dieta van afectar negativament a la producció lletera i a la condició corporal de les conilles al deslletament, així com al pes de les ventrades al deslletament. Tan mateix, aquests canvis van reduir la mortalitat dels llorigons en post-deslletament, amb efectes que van ser additius.

En un segon experiment, es va estudiar l'efecte dels vuit pinsos anteriors sobre l'ambient cecal dels llorigons en creixement. Es van utilitzar mostres d'animals sacrificats als 35 dies d'edat, que havien estat rebent un dels vuit pinsos experimentals des del dia 17 i s'havien deslletat als 28 dies. Les modificacions en la dieta van afectar principalment a la concentració cecal d'àcids grassos volàtils (incrementant-la) o/i d'amoníac (disminuint-la), creant un ambient més favorable per al manteniment de l'estabilitat de l'ecosistema microbià cecal i per tant de la salut digestiva, el que explicaria la reducció de la mortalitat observada en l'experiment anterior. 
En el tercer experiment, es van estudiar els efectes d'un sistema d'alimentació basat en la utilització d'un pinso peri-deslletament de baixa concentració nutritiva (favorable per a la salut digestiva dels llorigons d'acord als resultats dels experiments anteriors) i d'un sistema reproductiu extensiu (inseminació als 25 dies i deslletament als 42 dies), mitjançant un disseny factorial $2 \times 2$, comparant-los amb el sistema d'alimentació convencional $\mathrm{i}$ amb el sistema reproductiu semi-intensiu (inseminació als 11 dies i deslletament als 28 dies) durant cinc cicles productius. Com al primer experiment, el pinso peri-deslletament es va administrar des del dia 17 de lactació fins al deslletament en el cas de les conilles i fins al dia 49 en el cas dels llorigons. El sistema d'alimentació basat en el pinso peri-deslletament de baixa concentració nutritiva $\mathrm{i}$ el sistema reproductiu extensiu van donar lloc a diferents efectes negatius al llarg dels diferents cicles productius (menor producció lletera, menor pes de les conilles, menor pes de les ventrades al part, menor pes dels llorigons al deslletament), posant de manifest un procés d'adaptació de les conilles a la disponibilitat limitada de recursos i al major esforç fisiològic degut a lactacions més llargues. Per contra, ambdues estratègies van reduir la mortalitat dels conills en creixement.

En resum, els resultats d'aquesta tesi indiquen que tant la utilització de pinsos peri-deslletament de baixa concentració nutritiva com el retard de l'edat al deslletament penalitzen el rendiment de les conilles i redueixen la mortalitat dels llorigons en creixement en un context d'Enteropatia Epizoòtica del Conill. Malgrat aquesta reducció, les taxes de mortalitat registrades van ser clarament superiors a les acceptables en un sistema racional $i$ viable de producció de conill. 


\section{ABBREVIATIONS}

ADF: acid detergent fibre

ADL: acid detergent lignin

AOAC: Association of Official Analytical Chemists

CIAD: coefficient of ileal apparent digestibility

CP: crude protein

DE: digestible energy

DM: dry matter

dpp: day post-partum

EBE: estimated body energy

ERE: Epizootic Rabbit Enteropathy

FCR: feed conversion rate

FS: feeding system

NDF: neutral detergent fibre

NDSF: neutral detergent soluble fibre

PFT: perirenal fat thickness

PO: parity order

RS: reproductive system

VFA: volatile fatty acids 



\section{INDEX}

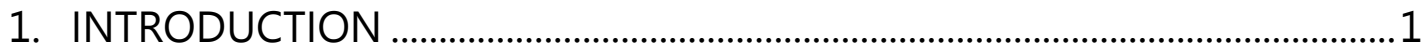

1.1. Feeding and management of young rabbit..............................................

1.2. Feeding and management of rabbit does ................................................... 6

1.3. References …………………………………………………………....

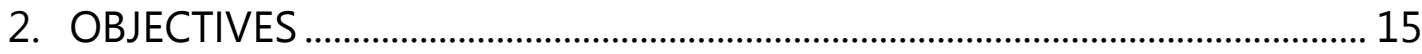

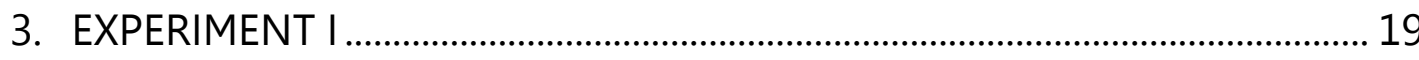

Combined feeding of rabbit female and young: partial replacement of starch with acid detergent fibre or/and neutral detergent soluble fibre at two protein levels ...................................................................................................... 21

- Abstract .................................................................................................. 21

- Introduction .......................................................................................... 23

- Material and Methods ................................................................................. 24

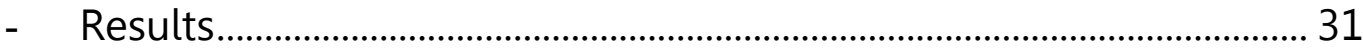

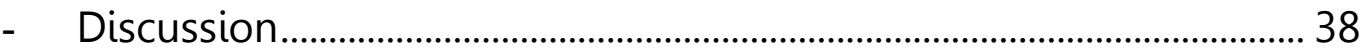

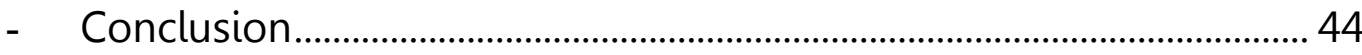

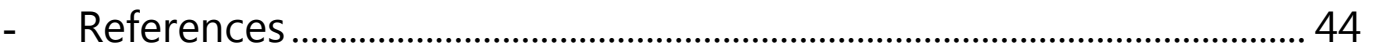

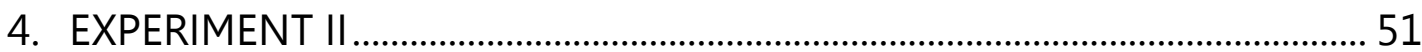

Partial replacement of starch with acid detergent fibre or/and neutral detergent soluble fibre at two protein levels: effects on ileal apparent digestibility and caecal environment of growing rabbits ............................... 53

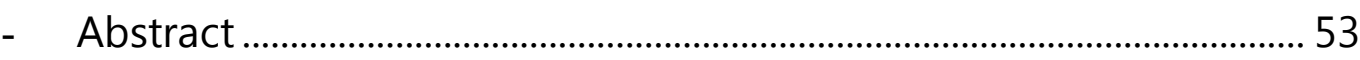

- Introduction .............................................................................................. 55

- Material and Methods .................................................................................. 56

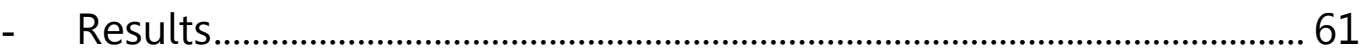

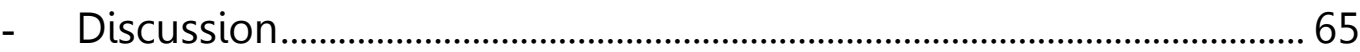

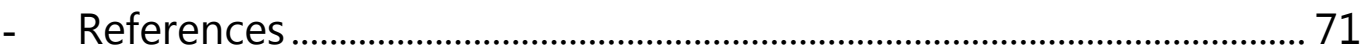


5. EXPERIMENT III …………………………………………………………….....

Use of a weaning diet in combined feeding of females and young rabbits under two reproductive systems ..........................................................................

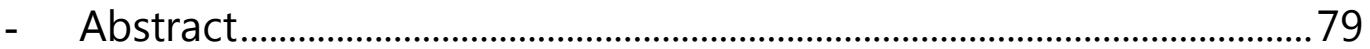

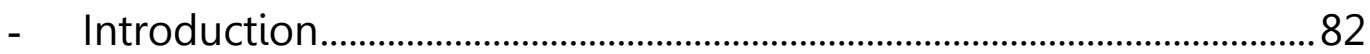

- Material and Methods..................................................................................83

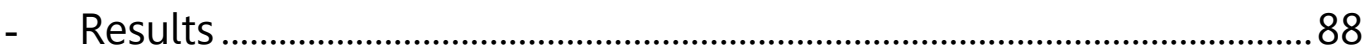

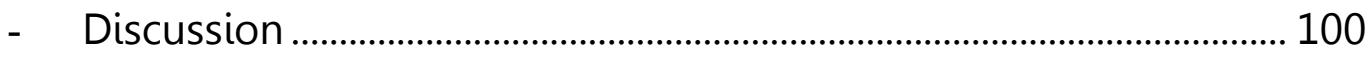

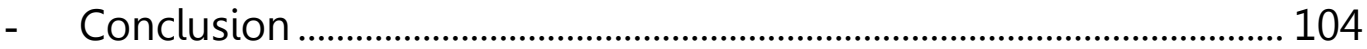

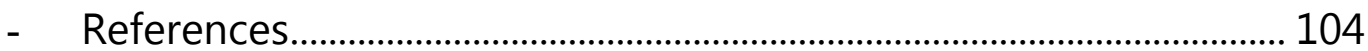

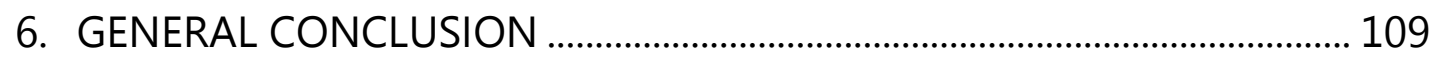

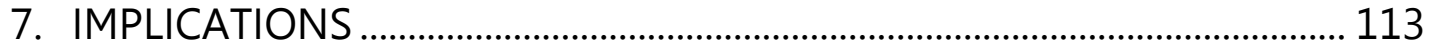




\section{INTRODUCTION}





\section{1. - Feeding and management of young rabbit}

Until the third week of life, the pups are fed exclusively with maternal milk, so that any strategy that favours milk production (amount and composition) at the onset of lactation is interesting for their growth and survival. Afterwards, aspects concerning the milk and feed that they consume must be taken into account.

Thus, many works have demonstrated that greater milk consumption in the second part of lactation has positive effects on growth and weight at weaning, which in general is associated with a better health status in the growing period. In this line, Fortun-Lamothe and Gidenne (2000) observed a remarkable reduction in post-weaning mortality in pups coming from small litters, which ingested more milk but less feed during lactation than those from larger litters. Also, Gallois et al. (2005) verified that milk confers a transitory protection against the colibacillosis by Escherichia coli O103; this protective capacity of milk would be related with its content in antibacterial or bacteriostatic substances (medium chain fatty acids, peptides from casein hydrolysis, defensins, enzymes, fucosylated oligosaccharides) and $\lg \mathrm{A}$, as well as in polypeptide growth factors (TGF-B, EGF, IGF) and polyamides that would stimulate the regeneration of damaged epithelia, although knowledge currently available on rabbit milk is limited (Cañas-Rodríguez and Smith, 1966; Baranyi et al., 1995 and 2003; Buret et al., 1998; Maertens et al., 2006). Moreover, it should be taken into account that the milk could affect caecal environment (Nizza et al., 2002; Di Meo et al., 2003; Xiccato et al., 2003).

In contrast, it has been suggested that a reduction in milk intake, with the increase of feed ingestion that it leads to, could suppose a less abrupt weaning and less risk of digestive disorders in post-weaning. However, this hypothesis is based on works where the differences in milk production were induced by using different feeds for rabbit does which were consumed also by their litters, so that changed not only the amount of feed consumed by the suckling rabbits but also its composition which could affect the caecal 
microbiota and environment. On the other hand, encouraging the early consumption of feed with no detriment to the milk ingestion seems to improve the growth of the litters and reduce the sanitary incidents after weaning (Maertens and De Groote, 1990).

It is known that around weaning a series of modifications dictated by the transition of milky to solid feeding will take place concerning the morphology and function of the intestinal mucosa, the caecal microbiota and its fermentative activity and the gut associated lymphoid tissue (Padilha et al., 1994; Marounek et al., 1995; Piattoni et al., 1995; Dojana et al., 1998; Piattoni y Maertens, 1999; Scapinello et al., 1999; Lanning et al., 2000; Debray et al., 2001). However, the rabbit is among livestock mammals the only animal that receives a non-specific diet around weaning: from the beginning of the solid intake at about 17 days of age until weaning (usually at 28-32 days of age) the litters have only access to a diet formulated to meet the nutritive requirements of lactating rabbit does, and after weaning young rabbits are commonly fed on a growing diet until the slaughtering. This fact could increase the susceptibility of young rabbits to suffer digestive disorders.

Recommendations to formulate diets for weaned young rabbits are established (De Blas and Mateos, 1998). Since the late nineties, the Epizootic Rabbit Enteropathy (ERE), which aetiology is not yet established, has worrying consequences on mortality of young rabbits and diet has been considered as an epidemiological risk factor, making essential the optimization of feed formulation to promote a correct morphological, physiological and immunological development of the digestive tract, as well as the growth of beneficial enteric flora. In fact, the recommended dietary levels to maximise growth of young rabbits are not probably the optimal to induce the greatest immunological/defence capacity (Fortun-Lamothe and Boullier, 2007).

The suitable development of caecal compartment from the onset of solid intake, involving microbial colonization and fermentative activity, seems crucial to reduce mortality in the post-weaning period. To this end, the role of 
fibre in young rabbit nutrition has been widely reviewed (De Blas et al., 1999; Gidenne, 2003; Gidenne and García, 2006). It has been verified that the increase of indigestible fibre (lignin and cellulose) at the expense of starch reduces the rate of digestive disorders by increasing the digestive rate of passage (Gidenne, 2003). Similarly, increasing the digestible fibre content (pectins and hemicelluloses) to replace starch promotes the development of the fermentative area (Gidenne and Bellier, 2000) and leads to lower postweaning mortality (Perez et al., 2000; Soler et al., 2004). Gómez-Conde et al. (2007) observed that the increase in neutral detergent soluble fibre at the expense of the insoluble fibre improves the morphology of the intestinal mucosa and enterocyte activity, produces greater local lymphocyte activation, reduces the presence of Clostridium perfringens and diminishes mortality. It has also been observed that a reduction in the dietary protein level, or the use of more digestible protein sources, reduces the ileal nitrogen flow and the incidence of digestive disorders (Gutiérrez et al., 2003; Chamorro et al., 2007). However, dietary changes are usually complex and involve several nutrients, making difficult to elucidate their respective effects and the comparison of results from different studies.

Along with the suitability of the nutritional content of feed, restricted feeding is a useful strategy for the control of digestive disorders. During the $3^{\text {rd }}$ and $4^{\text {th }}$ weeks of life, the solid ingestion of the pups is multiplied by 25 (Gidenne and Fortun-Lamothe, 2002) and the bulimia after weaning can favour these disorders. So, it has been observed that a reduction of postweaning feed intake by $20 \%$ diminishes the incidence of diarrhoeas (Gidenne et al., 2003) and improves resistance against the experimental inoculation of ERE (Boisot et al., 2003), with subsequent compensation for the delay in growth.

One of the main problems for the use of weaning diets resides in the difficulty to implement it in the field conditions, which requires the use of complex differentiated feeding systems (Fortun-Lamothe et al., 2000). An early weaning has been suggested as a beneficial strategy that would anticipate the 
use of a specific diet for young rabbits and the adaptation to solid intake, diminishing the risk of suffering digestive disorders (Pascual, 2001). However, the results when using this strategy are unlike; thus, Trocino et al. (2001) did not observe negative effect of early weaning on health status of young rabbits during the growth period, while Gidenne and Fortun-Lamothe (2001) found a higher mortality rate during the growth period when weaning at 23 days of age than at 32 days of age.

A practical solution would be the combined feeding of suckling rabbits and females with a weaning diet, the young rabbits consuming this diet also during the post-weaning period while the rabbit does consume it exclusively until weaning. When rabbit does received a weaning diet since the third week of lactation until weaning, the appearance of negative effects on them (reduction in milk production, impairment of body condition or health) seems to depend essentially upon whether there is a drop in feed intake as a result of diet switching (Chmitelin et al., 1990; Debray et al., 2002) or not (Morisse et al., 1989; Fortun-Lamothe et al., 2001).

On the other hand, from the appearance of ERE, a clear trend to change the usual reproductive management delaying both insemination and weaning has been observed in the field conditions, associated with an empiric decrease in mortality rate of young rabbits during the growth period.

\section{2. - Feeding and management of rabbit does}

In the last decades a high selection pressure have been carried out on rabbit does. One of the main target traits has been the litter size which supposes an increase in milk yield. This fact, joint to the intensification of reproductive rhythms have led to higher nutritive requirements of the does.

In some reviews (Fortun-Lamothe, 2005; Pascual, 2005), it is noted that during the pre-partum period and the first lactation of the does, a clear energy deficit takes place, with losses in body weight and mobilisation of reserves, estimated by means of comparative slaughters, changes in the 
thickness of perirenal fat and modification of electrical conductivity. This negative energy balance seems to be related to the low ingestion capacity of primiparous does in relation to the productive level and/or with the relatively good body condition with which primiparous does confront their first lactation (although the live weight still is not adult, the body reserves are usually sufficient). Also, due to the above mentioned selection for litter size involving higher milk yield, if the energy requirements are not well covered, an impairment of the foetuses growth in the concurrent pregnancy is produced (Fortun and Lebas, 1994).

After weaning, the main factor that influences the ingestion and recovery of reserves for the following cycle are the simultaneity or not of the lactation with the following pregnancy. When primiparous does are inseminated during the lactation period, they usually present a worse body condition at the second parturition than if mated later, essentially due to a shorter recovery time between weaning and parturition (Bolet and Fortun-Lamothe, 2002). For this reason, it has been suggested the delay of the insemination and the shortening of lactation as positive strategies to improve the future reproductive live of the rabbits does (Feugier and Fortun-Lamothe, 2006). Moreover, it would be beneficial the use of more energetic feeds (rich in fat or starch) that increase the energy intake during the first lactation, used to improve milk yield and/or reduce the mobilisation of body reserves (Pascual et al., 1998).

On the other hand, in multiparous does an increase of their body reserves is observed during the first 11 days of lactation (Bolet and FortunLamothe, 2002; Quevedo et al., 2006). Thereafter, the energy balance seems to depend more on the intensity of the reproductive rhythm. Thus, Quevedo et al. (2006) did not observe any important changes in perirenal fat thickness until weaning in does subjected to a semi-intensive rhythm (interval between parturitions of 56 days), while Xiccato et al. (2004) indicated that the multiparous does that synchronise lactation and pregnancy to a greater degree (interval between parturitions of 42 days) presented energy deficit 
during the second part of lactation, at least until the third lactation. FortunLamothe (2005) and Pascual (2005) emphasized that the body condition of multiparous rabbit does at parturition is very dependent upon their preceding reproductive history. In fact, Bolet and Fortun-Lamothe (2002) demonstrated that the main determinant of body condition at the third parturition is the simultaneity or not of lactation and gestation in the two preceding cycles, observing that the total body energy at third parturition of rabbit does inseminated after weaning was clearly higher than in rabbit does inseminated during lactation in both preceding cycles. It seems, therefore, that the multiparous rabbit does reach parturition with more precarious body reserves than primiparous does as a result of the successive productive cycles, taking advantage of their greater ingestion capacity to try to recover body condition in the first days of lactation, whereas thereafter the energy balance seems to be related to the productive pressure that they are subjected to, which is greater when the earlier is the insemination and the later is the weaning.

On the other hand, Theilgaard et al. (2006) suggested that rabbit does with poor body condition have greater risk of being eliminated and that the over-fattening would also go against their longevity. In this sense, Quevedo et al. (2006) found that rabbit does reaching the $5^{\text {th }}-6^{\text {th }}$ reproductive cycle improved their body reserves after the weaning of the $1^{\text {st }}$ and $2^{\text {nd }}$ lactations, whereas those eliminated before the third parturition (due to reproductive problems, disease or death) did not recover and even lost body condition. These results would indicate the importance of the management of the body reserves of the does until they reach adult size, since it could be a determining factor in their life expectancy on the farm. The use of energy feeds in multiparous does pursues the same aims as in primiparous does, but the advantages are not so relevant when the ingestion capacity is not so limiting (Pascual et al., 2003). 


\section{3. - References}

Baranyi, M., Brignon, P., Anglade, P., Ribadeau-Dumas, B., 1995. New data on the proteins of rabbit (Oryctolagus cuniculus) milk. Comp. Biochem. Physiol. 111B, 407-415.

Baranyi, M., Thomas, U., Pellegrini, A., 2003. Antibacterial activity of caseinderived peptides isolated from rabbit (Oryctolagus cuniculus) milk. J. Dairy Res. 70, 189-197.

Bolet, G., Fortun-Lamothe, L., 2002. Relationship between body condition and reproductive performance in rabbit does. Proc. $3^{\text {rd }}$ Meeting of Workgroups 1 (Reproduction) and 4 (Nutrition), Cost Action 848, Ispra (Italy), 48.

Boisot, P., Licois, D., Gidenne, T., 2003. Feed restriction reduces the sanitary impact of an experimental reproduction of Epizootic Rabbit Enteropathy syndrom (ERE), in the growing rabbit. Proc. $10^{\text {èmes }}$ Journées Recherche Cunicole, Paris (France), 267-270.

Buret, A., Olson, M.E., Gall, D.G., Hardin, J.A., 1998. Effects of orally administered Epidermal Growth Factor on enteropathogenic Escherichia coli infection in rabbits. Infect. Immun. 66, 4917-4923.

Cañas-Rodríguez, A., Smith, H.W., 1966. The identification of the antimicrobial factors of the stomach content of suckling rabbits. Biochem. J. 100, 7982.

Chamorro, S., Gómez-Conde, M.S., Pérez de Rozas, A.M., Badiola, I., Carabaño, R., De Blas, J.C., 2007. Effect on digestion and performance of dietary protein content and of increased substitution of lucerne hay with soyabean protein concentrate in starter diets for young rabbits. Animal 1 , 651-659.

Chmitelin, F., Hache, B., Rouillere, H., 1990. Alimentation de presévrage. Interet pour les laperaux. Repercussions sur les performances de reproduction des femelles. Proc. 5èmes Journées Recherche Cunicole, Paris (France), comm. 60, 9pp. 
De Blas, J.C., Mateos, G.G., 1998. Feed formulation. In: De Blas, J.C., Wiseman, J. (Eds.), The Nutrition of the Rabbit, CABI Publishing, Wallingford (UK), pp. 241-253.

De Blas, J.C., García, J., Carabaño, R., 1999. Role of fibre in rabbit diets. A review. Ann. de Zootech. 48, 3-13.

Debray, L., Gidenne, T., Fortun-Lamothe, L., 2001. Evolution of intestinal enzymatic capacity of rabbit around weaning. Proc. $2^{\text {nd }}$ Meeting of Workgroups 3 (Pathology and Prophylaxy) and 4 (Nutrition), COST Action 848, Gödollo (Hungary), 37.

Debray, L., Fortun-Lamothe, L., Gidenne, T., 2002. Influence of low dietary starch/fibre ratio around weaning on intake behaviour, performance and health status of young and rabbit does. Anim. Res. 51, 63-75.

Di Meo, C., Stanco, G., Piccolo, G., Taranto, S., Gazanero, M.P., Nizza, A., 2003. Productive performance of rabbits according to pre-weaning solid feed and milk intake. Ital. J. Anim. Sci. 3, 51-58.

Dojana, N., Costache, M., Dinischiotu, A., 1998. The activity of some digestive enzymes in domestic rabbits before and after weaning. Anim. Sci. 66, 501-507.

Feugier, A., Fortun-Lamothe L., 2006. Extensive reproductive rhythm and early weaning improve body condition and fertility of rabbit does. Anim. Res. $55,459-470$.

Fortun, L., Lebas, F., 1994. Effect de l'origine et de la teneur en energie de l'aliment sur les performances de reproduction de lapines primipares saillies post-partum. Premiers resultats. Proc. $6^{\text {èmes }}$ Journées Recherche Cunicole, La Rochelle (France), 285-292.

Fortun-Lamothe, L., 2005. Energy balance and reproductive performance in rabbit does. Review. Anim. Reprod. Sci. 93, 1-15. 
Fortun-Lamothe, L., Boullier, S., 2007. A review on the interactions between gut microflora and digestive mucosal immnunity. Possible ways to improve the health of rabbits. Livest. Sci. 107, 1-18.

Fortun-Lamothe, L., Gidenne, T., 2000. Effects of the suckled litter size on intake behaviour, performances and health status of young and reproducing rabbits. Ann. Zootech. 49, 517-529.

Fortun-Lamothe, L., Gidenne, T., Lapanouse, A., De Dapper, J., 2000. Technical note: An original system to separately control litter and female feed intake without modification of the mother-young relations. World Rabbit Sci. 8, 177-180.

Fortun-Lamothe, L., Gidenne, T., Debray, L., Chalaye, F., 2001. Intake regulation, performances and health status according to feeding strategy around feeding. Proc. $2^{\text {nd }}$ Meeting of Workgroups 3 (Pathology and Prophylaxy) and 4 (Nutrition), COST Action 848, Gödollo (Hungary), 40-41.

Gallois, M., Boullier, S., Milon, A., Gidenne, T., 2005. Age au sevrage et sensibilité à une infection expérimentale par une souche d'E. coli O103. Proc. $11^{\text {èmes }}$ Journées Recherche Cunicole, Paris (France), 249-252.

Gidenne, T., 2003. Fibres in rabbit feeding for digestive troubles prevention: respective role of low-digested and digestible fibre. Livest. Prod. Sci. 81, 105-117.

Gidenne, T., Bellier, R., 2000. Use of digestible fibre in replacement to available carbohydrates. Effect on digestion, rate of passage and caecal fermentation pattern during the growth of the rabbit. Livest. Prod. Sci. 63, 141-152.

Gidenne, T., Fortun-Lamothe, L., 2001. Early weaning: effect on performance and health. Proc. $2^{\text {nd }}$ Meeting of Workgroups 3 (Pathology and Prophylaxy) and 4 (Nutrition), COST Action 848, Gödollo (Hungary), 44. 
Gidenne, T., Fortun-Lamothe, L., 2002. Feeding strategy for young rabbit around weaning: a review of digestive capacity and nutritional needs. Anim. Sci. 75, 169-184.

Gidenne, T., García, J., 2006. Nutritional and feeding strategies improving the digestive health of the young rabbit. In: Maertens, L., Coudert, P. (Eds.), Recent Advances in Rabbit Sciences, ILVO, Melle (Belgium), pp. 229-238.

Gidenne, T., Feugier, A., Jehl, N., Arveux, P., Boisot, P., Briens, C., Corrent, E., Fortune, H., Montessuy, S., Verdelhan, S., 2003. A quantitative postweaning feed restriction reduces the incidence of diarrhoea, without major impact on growth performances: results of a multi-site study. Proc. $10^{\text {èmes }}$ Journées Recherche Cunicole, Paris (France), 29-32.

Gómez-Conde, M.S., García, J., Chamorro, S., Eiras, P., Rebollar, P.G., Pérez de Rozas, A., Badiola, I., De Blas, J.C., Carabaño, R., 2007. Neutral detergentsoluble fiber improves gut barrier function in twenty-five-day-old weaned rabbits. J. Anim. Sci. 85, 3313-3321.

Gutiérrez, I., Espinosa, A., García, J., Carabaño, R., De Blas, J.C., 2003. Effect of protein source on digestion and growth performance of early-weaned rabbits. Anim. Res. 52, 461-471.

Lanning, D., Zhu, X., Zhai, S., Knight, K.L., 2000. Development of the antibody repertory in the rabbit: gut-associated lymphoid tissue, microbes and selection. Immunol. Rev. 175, 214-228.

Maertens, L., De Groote, G., 1990. Feed intake of rabbit kits before weaning and attempts to increase it. J. Appl. Rabbit Res. 13, 151-158.

Maertens, L., Lebas, F., Szendrö, Z., 2006. Rabbit milk: a review of quantity, quality and non dietary affecting factors. World Rabbit Sci. 14, 205-230.

Marounek, M., Vovk, S.J., Skrivanova, V., 1995. Distribution of activity of hydrolytic enzymes in the digestive tract of rabbits. Br. J. Nutr. 73, 463469. 
Morisse, J.P., Maurice, R., Cotte, J.P., Le Gall, G., 1989. Effect of a pre-weaning diet on some physiological and production parameters in rabbits. J. Appl. Rabbit Res. 12, 190-193.

Nizza, A., Stanco, G., Di Meo, C., Marongiu, M.L., Taranto, S., Cutrignelly, M.l., Juliano, L., 2002. Effect of pre-weaning solid feed and milk intake on caecal content characteristics and performance of rabbits around weaning. Ital. J. Anim. Sci. 2, 95-101.

Padilha, T.S.M., Licois, D., Gidenne, T., Carré, B., Fonty, G., 1994. Evolution de la microflore et de l'activité caecale chez le lapereau pendant la période peri-sevrage: premiers résultats. Proc. $6^{\text {èmes }}$ Journées Recherche Cunicole, La Rochelle (France), 341-346.

Pascual, J.J., 2001. Early weaning of young rabbits: a review. World Rabbit Sci. 9, 165-170.

Pascual, J.J., 2005. Necesidades nutricionales de las conejas reproductoras: hacia la búsqueda de estrategias globales. Proc. III Jornadas Internacionais Cunicultura, Vila-Real (Portugal), 1-25.

Pascual, J.J., Cervera, C., Blas, E., Fernández-Carmona, J., 1998. Effect of the high fat diets on the performance and food intake of primiparous and multiparous rabbit does. Anim. Sci. 66, 491-499.

Pascual, J.J., Cervera, C., Blas, E., Fernández-Carmona, J., 2003. High energy diets for reproductive rabbit does: effect of energy source. Nutr. Abstr. Rev. Series B: Livestock Feeds and Feeding 73 (5), 27R-39R.

Perez, J.M., Gidenne, T., Bouvarel, I., Arveux, P., Bourdillon, A., Briens, C., Le Naour, J., Messager, B., Mirabito, L., 2000. Replacement of digestible fibre by starch in the diet of the growing rabbit. II. Effects on performances and mortality by diarrhoea. Ann. Zootech. 49, 369-377.

Piattoni, F., Maertens, L., 1999. Effect of weaning age and solid feed distribution before weaning on the caecal fermentation pattern of young rabbits. Proc. 11 Arbeitstagung über Haltung und Krankheiten der Kaninchen, Pelztiere und Heimtiere, Celle (Germany), 97-105. 
Piattoni, F., Maertens, L., Demeyer, D., 1995. Age dependent variation of caecal contents composition of young rabbits. Arch. Anim. Nutr. 48, 347-355.

Quevedo, F., Cervera, C., Blas, E., Baselga, M., Pascual, J.J., 2006. Long-term effect of selection for litter size and feeding programme on the performance of reproductive rabbit does. 2. Lactation and growing period. Anim. Sci. 82, 751-762.

Scapinello, C., Gidenne, T., Fortun-Lamothe, L., 1999. Digestive capacity of the rabbit during the post-weaning period according to milk/solid feed intake pattern before weaning. Repr. Nutr. Develop. 39, 423-432.

Soler, M.D., Blas, E., Cano, J.L., Pascual, J.J., Cervera, C., Fernández-Carmona, J., 2004. Effect of digestible fibre/starch ratio and animal fat level in diets around weaning on mortality rate of rabbits. Proc. $8^{\text {th }}$ World Rabbit Congress, Puebla (México), 996-1001, www.world-rabbit-science.com.

Theilgaard, P., Sánchez, J.P., Pascual, J.J., Friggens, N.C., Baselga, M., 2006. Effect of body fatness and selection for prolificacy on survival of rabbit does assessed using a cryopreserved control population. Livest. Prod. Sci. $103,65-73$.

Trocino, A., Xiccato, G., Sartori, A., Queaque, P.I., 2001. Effect of starter diet and weaning age on growth, caecal fermentation and body composition of young rabbits. Proc. $2^{\text {nd }}$ Meeting of Workgroups 3 (Pathology and Prophylaxy) and 4 (Nutrition), COST Action 848, Gödollo (Hungary), 5253.

Xiccato, G., Trocino, A., Sartori, A., Queaque, P.I., 2003. Effect of weaning diet and weaning age on growth, body composition and caecal fermentation of young rabbits. Anim. Sci. 77, 101-111.

Xiccato, G., Trocino, A., Santori, A., Queaque, P.I., 2004. Effect of parity order and litter weaning age on the performance and body energy balance of rabbit does. Livest. Prod. Sci. 85, 239-251. 

In view of the above described state of the art, the hypothesis postulated in the current study is that nutritional requirements of young rabbits and lactating rabbit does are antagonist, in such a way that less concentrated weaning diets used in combined feeding could contribute to the digestive health of the young rabbits although they could impair performance of rabbit does, particularly in the long term.

Thus, the specific objectives of this thesis are:

- To evaluate the effects of weaning diets differing because of partial replacement of starch with acid detergent fibre or/and neutral detergent soluble fibre and in the protein level on growth and health of young rabbits, as well as on performance and body condition of rabbit does.

- To evaluate the effects of the above mentioned weaning diets on ileal apparent digestibility and caecal environment of growing rabbits.

- To compare the conventional system of feeding and reproductive management with an experimental system based on the use of a weaning diet or/and the increase of the parturition-insemination interval and weaning age, as regards the effects in the long term on performance and body condition of rabbit does and mortality of growing rabbits. 



\section{EXPERIMENT I}

Published in Livestock Science 141 (2011), 155-165

doi:10.1016/j.livsci.2011.05.014 



\section{Combined feeding of rabbit female and young: partial replacement of starch with acid detergent fibre or/and neutral detergent soluble fibre at two protein levels}

B. Martínez-Vallespín, E. Martínez-Paredes, L. Ródenas, C. Cervera, J.J. Pascual, E. Blas

Institute of Animal Science and Technology. Universidad Politécnica de Valencia, Camino de Vera s/n. 46022 Valencia, Spain.

\section{Abstract}

To evaluate the effects of the composition of weaning diets used for combined feeding both on the performance and body condition of rabbit does and on the growth and health of young rabbits, eight experimental diets were formulated according to a factorial design $2 \times 2 \times 2$, the three factors being: i) partial replacement of starch with acid detergent fibre (ADF), ii) partial replacement of starch with neutral detergent soluble fibre (NDSF) and iii) reduction of the crude protein (CP) content from 175 to $145 \mathrm{~g} \mathrm{~kg}^{-1}$ dry matter (DM). The study involved 138 rabbit does and 318 litters fed experimental diets from $17^{\text {th }}$ to $28^{\text {th }}$ day of lactation (weaning). Thereafter, 2371 weaned rabbits (784 in individual cages and 1587 in collective ones) continued receiving the same experimental diets until 49 days of age and a commercial finishing diet until 60 days of age. Replacing starch with ADF increased feed intake of does $\left(+26 \pm 5 \mathrm{~g} \mathrm{DM} \mathrm{day}^{-1}, P<0.001\right)$ but, only with high CP diets, impaired their milk yield $\left(-15 \pm 6 \mathrm{~g} \mathrm{day}^{-1}, P<0.01\right)$ and perirenal fat thickness (PFT) change $(-0.41 \pm 0.13 \mathrm{~mm}, P<0.01)$, as well as litter weight at weaning $(-154 \pm 52 \mathrm{~g}, \quad P<0.01)$; from weaning to 49 days of age, this replacement 
increased feed intake $\left(+14 \pm 2 \mathrm{~g} \mathrm{DM} \mathrm{day}^{-1}, P<0.001\right)$ and impaired live weight gain $\left(-1.6 \pm 0.7 \mathrm{~g} \mathrm{day}^{-1}, P<0.05\right)$, but reduced mortality rate $(-10.2 \%, P<0.001)$ of growing rabbits. Replacing starch with NDSF reduced feed intake of does, in greater extent with high CP diets $\left(-34 \pm 6 \mathrm{~g} \mathrm{DM}\right.$ day $\left.^{-1}, P<0.001\right)$ than with low $\mathrm{CP}$ diets $\left(-19 \pm 7 \mathrm{~g} \mathrm{DM}\right.$ day $\left.^{-1}, P<0.01\right)$, as well as their milk yield $\left(-16 \pm 4 \mathrm{~g} \mathrm{day}^{-1}\right.$, $P<0.001)$, with impairing PFT change only with high CP diets $(-0.30 \pm 0.13 \mathrm{~mm}$, $P<0.05)$; litter feed intake and weight at weaning were also negatively affected $\left(-14.4 \pm 2.5 \mathrm{~g} \mathrm{DM}\right.$ day $\left.^{-1},-202 \pm 38 \mathrm{~g}, P<0.001\right)$; from weaning to 49 days of age, this replacement reduced feed intake $\left(-8 \pm 2 \mathrm{~g} \mathrm{DM}\right.$ day $\left.^{-1}, P<0.001\right)$, impaired live weight gain only with low CP diets $\left(-2.3 \pm 1.0 \mathrm{~g} \mathrm{day}^{-1}, P<0.05\right)$ and reduced mortality rate $(-15.1 \%, P<0.001)$. Reducing $C P$ content affected negatively feed intake of does $\left(-22 \pm 5 \mathrm{~g} \mathrm{DM} \mathrm{day}^{-1}, P<0.001\right)$, as well as their milk yield, this impairment being more important with more starch-less ADF diets $(-24 \pm 5 \mathrm{~g}$ day $\left.^{-1}, P<0.001\right)$ than with less starch-more ADF diets $\left(-13 \pm 6 \mathrm{~g}\right.$ day $\left.^{-1}, P<0.05\right)$, and, only with more starch-less ADF diets, PFT change $(-0.36 \pm 0.13 \mathrm{~mm}$, $P<0.01)$; litter feed intake was affected negatively $\left(-20.1 \pm 2.4 \mathrm{~g} \mathrm{DM}\right.$ day $^{-1}$, $P<0.001)$, as well as litter weight at weaning, in great extent when fed more starch-less ADF diets $(-581 \pm 52 \mathrm{~g}, P<0.001)$ than when fed less starch-more ADF diets $(-403 \pm 54 \mathrm{~g}, P<0.001)$; from weaning to 49 days of age, this dietary change reduced feed intake $\left(-6 \pm 2 \mathrm{~g} \mathrm{DM}\right.$ day $\left.^{-1}, P<0.001\right)$ and impaired live weight gain $(-5.0 \pm 0.7 \mathrm{~g}, P<0.001)$, but reduced mortality rate $(-19.9 \%$, $P<0.001)$. Overall, the three dietary changes under study impaired milk yield, body condition of does and litter weight at weaning, although the negative effect of replacing starch with ADF was only observed in the high CP diets; moreover, growth during post-weaning period also decreased. However, in an Epizootic Rabbit Enteropathy context, mortality rate during this period was reduced by these three dietary changes, which effects seemed additive.

Keywords: rabbit, combined feeding, weaning diet, fibre, starch, protein. 


\section{Introduction}

One of the main handicaps of current intensive rabbit production is the frequent appearance of digestive troubles during the growth period, compromising farm viability. In the last decade, the digestive physiology and nutrition of young rabbits around weaning has been widely reviewed in order to define better their requirements and the adequate diet for minimizing these troubles. In fact, the level and type of some nutrients (such as fibre, starch or protein) have been frequently related with digestive health of young rabbit, although their respective effects are sometimes difficult to elucidate because dietary changes are usually complex and involve several nutrients. Moreover, diet should not be commonly considered as a primary cause of digestive troubles but as an epidemiological risk factor depending on other factors such as hygienic or sanitary status of farm, feeding management (age at weaning, diet switching, etc...) and use of antimicrobials agents; thus, it is not infrequent that the same dietary variations behave differently with respect to digestive health depending on the mentioned factors.

The beneficial effect of increasing dietary fibre replacing starch on digestive health of young rabbits is well established (Blas and Gidenne, 2010; De Blas et al., 1999; Gidenne and García, 2006; Gidenne et al., 2010). Depending on if low-digestible fibre (lignin, cellulose) or high-digestible fibre (pectins, hemicelluloses) are involved, promoted rate of passage of digesta in the caeco-colic segment or favourable changes in carbohydrate substrate for microbiota, fermentative activity and gut environment are mainly concerned. Reduction of dietary crude protein content has also positive effect on digestive health of young rabbits (Carabaño et al., 2009). This reduction has been related with lower ileal flow of nitrogen, caecal Clostridium perfringens population and mortality (Chamorro et al., 2007).

In spite of these nutritional advances, the standard management in rabbit farms makes difficult the use of specific diets for young rabbits before weaning, as usual in other mammals. Modifications in the cages and feeders 
has been proposed (Fortun-Lamothe et al., 2000), but a practical alternative would be a combined feeding of rabbit does and litters during late lactation (from $16^{\text {th }}-18^{\text {th }}$ day post-partum onward) with a weaning diet formulated to meet the requirements of young rabbits around weaning. However, the dietary changes above described as improving digestive health of young rabbits could be inadequate to meet the nutritive concentration required in diets for lactating rabbit does (De Blas and Mateos, 2010). Nevertheless, there is scarce knowledge about how these dietary changes could affect performance and body condition of rabbit females when applied exclusively during late lactation.

In view of the foregoing, the aim of the present work was to evaluate, in a factorial design, the effects of partial replacement of starch with acid detergent fibre (ADF), partial replacement of starch with neutral detergent soluble fibre (NDSF) and reduction in the crude protein (CP) content in the weaning diet used for combined feeding both on the performance and body condition of rabbit does and on the growth and health of young rabbits.

\section{Material and Methods}

\section{Diets}

Eight experimental weaning diets were formulated according to a factorial design $2 \times 2 \times 2$. The factors were the replacement of $50 \mathrm{~g} \mathrm{~kg}^{-1}$ dry matter (DM) of starch with ADF, the replacement of $50 \mathrm{~g} \mathrm{~kg}^{-1} \mathrm{DM}$ of starch with NDSF and the reduction of the CP content from 175 to $145 \mathrm{~g} \mathrm{~kg}^{-1} \mathrm{DM}$; this design allowed to compare all the combinations of these factors (LLH, $H L H, L H H, H H H, L L L, H L L, L H L$ and $H H L)$, where the first, second and third letters were respectively the dietary ADF, NDSF and CP contents (low or high; $\mathrm{L}$ or $\mathrm{H})$. The ingredient and chemical composition of the experimental diets are described in Tables 1 and 2, respectively. Starch was replaced by ADF mainly by reducing wheat grain $\left(-90 \mathrm{~g} \mathrm{~kg}^{-1} \mathrm{DM}\right)$, wheat bran $\left(-40 \mathrm{~g} \mathrm{~kg}^{-1} \mathrm{DM}\right)$ and grape pomace $\left(-70 \mathrm{~g} \mathrm{~kg}^{-1} \mathrm{DM}\right)$ and increasing oat hulls $\left(+60 \mathrm{~g} \mathrm{~kg}^{-1} \mathrm{DM}\right)$ 
and defatted grape seed (+130 $\left.\mathrm{g} \mathrm{kg}^{-1} \mathrm{DM}\right)$; starch was replaced by NDSF mainly by reducing wheat grain $\left(-90 \mathrm{~g} \mathrm{~kg}^{-1} \mathrm{DM}\right)$, soybean hulls $\left(-40 \mathrm{~g} \mathrm{~kg}^{-1} \mathrm{DM}\right)$ and treated wheat straw (-80 $\left.\mathrm{g} \mathrm{kg}^{-1} \mathrm{DM}\right)$ and increasing beet pulp $\left(+170 \mathrm{~g} \mathrm{~kg}^{-1}\right.$ DM) and oat hulls $\left(+50 \mathrm{~g} \mathrm{~kg}^{-1} \mathrm{DM}\right) ; \mathrm{CP}$ content was reduced mainly by replacing sunflower meal (-360 or $-355 \mathrm{~g} \mathrm{~kg}^{-1} \mathrm{DM}$ ) with soybean protein concentrate $\left(+75 \mathrm{~g} \mathrm{~kg}^{-1} \mathrm{DM}\right)$, beet pulp $\left(+60 \mathrm{~g} \mathrm{~kg}^{-1} \mathrm{DM}\right)$, defatted grape seed $\left(+60 \mathrm{~g} \mathrm{~kg}^{-1} \mathrm{DM}\right)$ and treated wheat straw $\left(+130\right.$ or $\left.+127.5 \mathrm{~g} \mathrm{~kg}^{-1} \mathrm{DM}\right)$. All the experimental diets included zinc bacitracin (100 ppm) and robenidine (66 ppm).

Chemical analyses of diets were performed according to the methods of the AOAC (2000): 934.01 for DM, 942.05 for ash, 976.06 for CP and 920.39 for ether extract, with acid-hydrolysis of samples prior to the extraction. Starch content was determined according to Batey (1982), by a two-step enzymatic procedure with solubilisation and hydrolysis to maltodextrins with thermostable $\alpha$-amylase followed by complete hydrolysis with amyloglucosidase (both enzymes from Sigma-Aldrich, Steinheim, Germany), and the resulting glucose being measured by the hexokinase/glucose- 6 phosphate dehydrogenase/NADP system (R-Biopharm, Darmstadt, Germany). Neutral detergent fibre (NDF), ADF and acid detergent lignin (ADL) fractions were analysed sequentially (Van Soest et al., 1991) with a thermo-stable $\alpha$-amylase pre-treatment and expressed exclusive of residual ash, using a nylon filter bag system (Ankom, Macedon, NY, USA). NDSF content was determined according to Hall et al. (1997), adapting the method to the nylon filter bag system and with the following modifications: a Soxhlet extraction of the samples with petroleum ether (6 hours) was performed prior to the ethanol-water extraction and the NDF fraction was determined from the ether-ethanol insoluble residue instead of from the raw sample. Pellet hardness was determined by manual spring durometer (Amandus-Kahl, Reinbek, Germany) measuring 25 pellets from each experimental diet. 
Table 1. Ingredient composition of the experimental diets ( $\mathrm{g} \mathrm{kg}^{-1}$ dry matter)

\begin{tabular}{|c|c|c|c|c|c|c|c|c|}
\hline Diets & LLH & $\mathrm{HLH}$ & LHH & $\mathrm{HHH}$ & LLL & HLL & LHL & $\mathrm{HHL}$ \\
\hline \multicolumn{9}{|l|}{ Nutrient level ${ }^{1}$} \\
\hline Acid detergent fibre & $\mathrm{L}$ & $\mathrm{H}$ & L & $\mathrm{H}$ & $\mathrm{L}$ & $\mathrm{H}$ & L & $\mathrm{H}$ \\
\hline Neutral detergent soluble fibre & $\mathrm{L}$ & $\mathrm{L}$ & $\mathrm{H}$ & $\mathrm{H}$ & $\mathrm{L}$ & $\mathrm{L}$ & $\mathrm{H}$ & $\mathrm{H}$ \\
\hline Crude protein & $\mathrm{H}$ & $\mathrm{H}$ & $\mathrm{H}$ & $\mathrm{H}$ & L & L & $\mathrm{L}$ & $\mathrm{L}$ \\
\hline \multicolumn{9}{|l|}{ Ingredients } \\
\hline Wheat grain & 180 & 90 & 90 & - & 180 & 90 & 90 & - \\
\hline Wheat bran & 40 & - & 40 & - & 40 & - & 40 & - \\
\hline Sunflower meal 28 & 360 & 355 & 360 & 355 & - & - & - & - \\
\hline Soybean protein concentrate 61 & - & - & - & - & 75 & 75 & 75 & 75 \\
\hline Fish meal 70 & 20 & 25 & 20 & 25 & 20 & 22.5 & 20 & 22.5 \\
\hline Beet pulp & 40 & 40 & 210 & 210 & 100 & 100 & 270 & 270 \\
\hline Oat hulls & 40 & 100 & 90 & 150 & 40 & 100 & 90 & 150 \\
\hline Defatted grape seed & 20 & 150 & 20 & 150 & 80 & 210 & 80 & 210 \\
\hline Grape pomace & 80 & 10 & 70 & - & 100 & 30 & 90 & 20 \\
\hline Soybean hulls & 40 & 40 & - & - & 40 & 40 & - & - \\
\hline Treated wheat straw & 80 & 80 & - & - & 210 & 207.5 & 130 & 127.5 \\
\hline Soybean oil & 50 & 50 & 50 & 50 & 50 & 50 & 50 & 50 \\
\hline Sugarcane molasses & 10 & 10 & 10 & 10 & 10 & 10 & 10 & 10 \\
\hline Corn starch & - & 10 & - & 10 & - & 10 & - & 10 \\
\hline L-Lysine $\mathrm{HCl}$ & 5 & 5 & 4.5 & 4.5 & 5.75 & 5.75 & 5 & 5 \\
\hline DL-Methionine & 1 & 1.25 & 1 & 1.25 & 4 & 4.25 & 4 & 4.25 \\
\hline L-Threonine & 1.5 & 1.75 & 1.25 & 1.5 & 3.5 & 3.75 & 3.25 & 3.5 \\
\hline L-Tryptophan & 1.5 & 1.5 & 1.5 & 1.5 & 2.25 & 2.25 & 2.25 & 2.25 \\
\hline Calcium carbonate & 12 & 8.5 & 11.25 & 7.75 & 3 & - & 3 & - \\
\hline Dicalcium phosphate & 10 & 13 & 11.5 & 14.5 & 27.5 & 30 & 28.5 & 31 \\
\hline Sodium chloride & 5 & 5 & 5 & 5 & 5 & 5 & 5 & 5 \\
\hline Vitamin/trace element premix $x^{2}$ & 4 & 4 & 4 & 4 & 4 & 4 & 4 & 4 \\
\hline
\end{tabular}

${ }^{1} \mathrm{~L}$, low; $\mathrm{H}$, high.

${ }^{2}$ Supplied per kg of feed: Vitamin A: 8.375 IU; Vitamin D3: $750 \mathrm{IU}$; Vitamin E: 20 mg; Vitamin $\mathrm{K}_{3}: 1 \mathrm{mg}$; Vitamin $\mathrm{B}_{1}: 1 \mathrm{mg}$; Vitamin $\mathrm{B}_{2}: 2 \mathrm{mg}$; Vitamin $\mathrm{B}_{6}: 1 \mathrm{mg}$; Nicotinic acid: $20 \mathrm{mg}$; Choline chloride: $250 \mathrm{mg}$; Magnesium: $290 \mathrm{mg}$; Manganese: $20 \mathrm{mg}$; Zinc: $60 \mathrm{mg}$; lodine: $1.25 \mathrm{mg}$; Iron: $26 \mathrm{mg}$; Copper: $10 \mathrm{mg}$; Cobalt: $0.7 \mathrm{mg}$; Butyl hydroxylanysole and ethoxiquin mixture: $4 \mathrm{mg}$. 
Table 2. Chemical composition of the experimental diets ( $\mathrm{g} \mathrm{kg}^{-1}$ dry matter)

\begin{tabular}{|c|c|c|c|c|c|c|c|c|}
\hline Diets & LLH & $\mathrm{HLH}$ & $\mathrm{LHH}$ & $\mathrm{HHH}$ & LLL & HLL & LHL & $\mathrm{HHL}$ \\
\hline \multicolumn{9}{|l|}{ Nutrient level $^{1}$} \\
\hline Acid detergent fibre & $\mathrm{L}$ & $\mathrm{H}$ & $\mathrm{L}$ & $\mathrm{H}$ & $\mathrm{L}$ & $\mathrm{H}$ & $\mathrm{L}$ & $\mathrm{H}$ \\
\hline Neutral detergent soluble fibre & L & L & $\mathrm{H}$ & $\mathrm{H}$ & $\mathrm{L}$ & L & $\mathrm{H}$ & $\mathrm{H}$ \\
\hline Crude protein & $\mathrm{H}$ & $\mathrm{H}$ & $\mathrm{H}$ & $\mathrm{H}$ & L & L & L & L \\
\hline \multicolumn{9}{|l|}{ Chemical composition } \\
\hline Organic matter & 921 & 923 & 925 & 923 & 911 & 914 & 918 & 919 \\
\hline Crude protein & 172 & 177 & 172 & 176 & 147 & 145 & 145 & 144 \\
\hline Ether extract & 89 & 74 & 89 & 77 & 86 & 77 & 85 & 69 \\
\hline Starch & 133 & 84 & 81 & 36 & 129 & 87 & 87 & 30 \\
\hline Neutral detergent fibre, NDF & 435 & 495 & 439 & 513 & 418 & 475 & 433 & 502 \\
\hline Acid detergent fibre, ADF & 236 & 292 & 236 & 310 & 228 & 282 & 229 & 290 \\
\hline Acid detergent lignin, ADL & 64 & 102 & 65 & 112 & 57 & 96 & 56 & 96 \\
\hline Insoluble hemicelluloses, NDF-ADF & 199 & 203 & 203 & 203 & 190 & 193 & 204 & 211 \\
\hline Cellulose, ADF-ADL & 172 & 190 & 171 & 198 & 170 & 186 & 173 & 195 \\
\hline Neutral detergent soluble fibre & 145 & 153 & 185 & 185 & 143 & 140 & 188 & 180 \\
\hline Digestible energy $^{2}\left(\mathrm{MJ} \mathrm{kg}^{-1}\right.$ dry matter) & 11.5 & 10.3 & 11.6 & 10.4 & 10.7 & 9.5 & 10.8 & 9.6 \\
\hline Hardness (kg) & 9.3 & 12.3 & 9.5 & 10.9 & 9.1 & 11.2 & 10.5 & 10.9 \\
\hline
\end{tabular}

\footnotetext{
${ }^{1} \mathrm{~L}$, low; $\mathrm{H}$, high.

${ }^{2}$ Calculated according to Villamide et al. (2010) and Fundación Española para el Desarrollo de la Nutrición Animal (2010).
}

\section{Animals and experimental procedure}

The experimental protocols followed both the Spanish Royal Decree 1201/2005 on the protection of animals used for scientific purposes (Boletín Oficial del Estado, 2005) and the recommendations for applied nutrition research in rabbits described by the European Group on Rabbit Nutrition (Fernández-Carmona et al., 2005), being approved by the Committee of Ethics and Animal Welfare of the Universidad Politécnica de Valencia.

Animals were housed in an experimental farm having a history of Epizootic Rabbit Enteropathy (ERE). The building was equipped with a forced ventilation and cooling system to maintain the temperature within the range of $12^{\circ} \mathrm{C}$ to $25^{\circ} \mathrm{C}$ throughout the experimental period (November to July). A photoperiod of 16 hours of light and 8 hours of darkness was established using artificial lights just in the months in which was needed. A lactation trial 
was carried out in the breeding unit, equipped with cages which dimensions were $50 \times 70 \times 32 \mathrm{~cm}$ and provided with nesting boxes, and a growth trial was conducted in the fattening unit using individual $(26 \times 50 \times 31 \mathrm{~cm})$ and collective cages $(50 \times 80 \times 32 \mathrm{~cm}, 8$ rabbits).

\section{Lactation trial}

One hundred and thirty-six rabbit does (maternal line A, Universidad Politécnica de Valencia, Spain) providing a total of 318 litters were used. Litters were standardized to 9-10 kits at birth. Until $17^{\text {th }}$ day of lactation, females received ad libitum a commercial diet for reproductive rabbit does (177 g CP, $155 \mathrm{~g}$ starch and $191 \mathrm{~g} \mathrm{ADF} \mathrm{kg}^{-1} \mathrm{DM}$ ). The does were inseminated at $11^{\text {th }}$ day post-partum, and each 21 days afterwards if needed, with pooled semen (growth line R, Universidad Politécnica de Valencia, Spain).

At $17^{\text {th }}$ day of lactation, females were separated from their litters to avoid free suckling, litters were re-standardised to 8-9 kits, transferring the remainder kits to nursing does, and both females and litters had free access to one of the experimental diets, randomly assigned. Until weaning $\left(28^{\text {th }}\right.$ day of lactation), females were taken to the litter cage once daily in the morning for a short time and milk production was measured from $21^{\text {st }}$ to $25^{\text {th }}$ day of lactation by weighing the doe immediately before and after suckling. After weaning, females were again fed ad libitum with the commercial feed for reproductive rabbit does.

Live weight of females was measured at $17^{\text {th }}$ and $28^{\text {th }}$ day of lactation, as well as their perirenal fat thickness (PFT) by echography (Pascual et al., 2000), using an ultrasound unit (JustVision 200, Toshiba Medical Systems, Tokyo, Japan) equipped with image analyser software to determine distances. Estimated body energy (EBE) content of does was determined from live weight and PFT of does, using the equation proposed by Pascual et al. (2004). Feed intake of females was controlled from $17^{\text {th }}$ day of lactation to weaning. Litter 
size and weight was registered at 17 days of age and weaning. Solid feed intake of litters was monitored from 17 days of age to weaning.

\section{Growth trial}

After weaning, 2371 young rabbits were distributed in two different allocations: 784 animals were housed in individual cages and 1587 in collective ones. All of them continued with the respective experimental diets until 49 days of age, when they were switched to a non-medicated commercial finishing diet (168 g CP, $163 \mathrm{~g}$ starch and $180 \mathrm{~g} \mathrm{ADF} \mathrm{kg}^{-1} \mathrm{DM}$ ) until 60 days of age. Live weight and feed intake were controlled for the animals allocated in individual cages at 28, 49 and 60 days of age. Mortality was monitored in both individual and collective cages.

\section{Statistical analysis}

Data were analysed by SAS software (Statistical Analysis Systems Institute, 2002). Traits from rabbit does and litters were analysed according to a mixed model (MIXED procedure) including the diet (LLH, HLH, LHH, HHH, LLL, HLL, LHL or HHL), the parity order (from 1 to 8 ) as repeated measure factor and the pregnancy status at $17^{\text {th }}$ day of lactation (pregnant or not pregnant), with a permanent effect of each rabbit doe and the error as random factors; litter size and weight at $17^{\text {th }}$ day of lactation were included as covariates when analysing data at weaning. Growth traits were analysed according to a mixed model (MIXED procedure) including the diet, the age (28, 49 or 60 days) as repeated measure factor, the interaction between diet and age and the growth batch (from 1 to 5), with a permanent effect of each animal (nested to diet and growth batch) and the error as random factors. Mortality rate during the growth period was analysed according to a generalized linear model (GENMOD procedure) including the diet as main factor. Pellet hardness was analysed according to a general linear model (GLM procedure) including the diet as main factor. 
Table 3. Effect of the weaning diet on performance of rabbit does and litters at weaning (28 ${ }^{\text {th }}$ day of lactation)

\begin{tabular}{|c|c|c|c|c|c|c|c|c|c|c|c|}
\hline & \multicolumn{8}{|c|}{ Diet $^{1}$} & \multicolumn{3}{|c|}{ Contrast $^{2}$ (estimate \pm standard error) } \\
\hline & LLH & $\mathrm{HLH}$ & $\mathrm{LHH}$ & $\mathrm{HHH}$ & LLL & HLL & LHL & $\mathrm{HHL}$ & ADF for starch & NDSF for starch & $\mathrm{CP}$ reduction \\
\hline Number of observations & 46 & 42 & 43 & 36 & 38 & 38 & 39 & 36 & & & \\
\hline \multicolumn{12}{|l|}{ Rabbit does } \\
\hline \multicolumn{12}{|l|}{$17^{\text {th }}$ day of lactation } \\
\hline Live weight (g) & 4384 & 4347 & 4398 & 4365 & 4384 & 4389 & 4435 & 4351 & $-37 \pm 23$ & $11 \pm 24$ & $16 \pm 22$ \\
\hline $\mathrm{PFT}^{3}(\mathrm{~mm})$ & 5.85 & 6.05 & 5.91 & 6.05 & 6.02 & 5.90 & 6.12 & 5.96 & $0.01 \pm 0.07$ & $0.06 \pm 0.07$ & $0.04 \pm 0.07$ \\
\hline $\mathrm{EBE}^{4}(\mathrm{MJ})$ & 37.2 & 36.4 & 37.4 & 36.5 & 36.8 & 37.5 & 38.0 & 37.0 & $-0.5 \pm 0.4$ & $0.3 \pm 0.4$ & $0.5 \pm 0.4$ \\
\hline \multicolumn{12}{|l|}{$17^{\text {th }}$ day of lactation to weaning } \\
\hline Feed intake (g dry matter day $^{-1}$ ) & $402^{\mathrm{b}}$ & $424^{a}$ & $366^{\text {de }}$ & $391^{\mathrm{bc}}$ & $367^{\text {de }}$ & $399^{b}$ & $352^{\mathrm{e}}$ & $377^{\mathrm{cd}}$ & $26 \pm 5^{\star \star \star}$ & $-26 \pm 5^{\star \star \star}$ & $-22 \pm 5^{\star \star \star}$ \\
\hline Digestible energy intake $\left(\mathrm{MJ}^{\mathrm{d}} \mathrm{yy}^{-1}\right.$ ) & $4.64^{\mathrm{a}}$ & $4.37^{\mathrm{b}}$ & $4.27^{\mathrm{b}}$ & $4.08^{\mathrm{bc}}$ & $3.93^{\mathrm{cd}}$ & $3.78^{\text {de }}$ & $3.81^{\text {de }}$ & $3.61^{\mathrm{e}}$ & $-0.21 \pm 0.05^{\star \star \star}$ & $-0.24 \pm 0.05^{\star \star \star}$ & $-0.56 \pm 0.05^{\star \star \star}$ \\
\hline Crude protein intake $\left(\mathrm{g} \mathrm{day}^{-1}\right)$ & $69.3^{\mathrm{b}}$ & $75.1^{a}$ & $63.0^{c}$ & $69.0^{\mathrm{b}}$ & $53.7^{\mathrm{e}}$ & $57.6^{d}$ & $50.6^{\dagger}$ & $53.8^{e}$ & $4.7 \pm 0.8^{\star \star \star}$ & $-4.8 \pm 0.8^{* \star *}$ & $-15.2 \pm 0.7^{\star \star *}$ \\
\hline Milk yield $\left(\mathrm{g} \mathrm{day}^{-1}\right)$ & $273^{a}$ & $260^{\mathrm{ab}}$ & $258^{\mathrm{b}}$ & $242^{\mathrm{cd}}$ & $248^{\mathrm{bc}}$ & $246^{\mathrm{bc}}$ & $234^{\mathrm{cd}}$ & $230^{d}$ & $-9 \pm 4^{*}$ & $-16 \pm 4^{\star \star \star}$ & $-19 \pm 4^{* * \star}$ \\
\hline Live weight change (g) & $185^{a}$ & $120^{\mathrm{ab}}$ & $118^{\mathrm{ab}}$ & $69^{\mathrm{bcd}}$ & $90^{\mathrm{b}}$ & $18^{\mathrm{cd}}$ & $88^{\mathrm{bc}}$ & $0^{d}$ & $-68 \pm 18^{\star \star \star}$ & $-35 \pm 18$ & $-74 \pm 18^{\star \star \star}$ \\
\hline $\mathrm{PFT}^{3}$ change $(\mathrm{mm})$ & $0.43^{a}$ & $-0.03^{b}$ & $0.09^{\mathrm{ab}}$ & $-0.28^{b}$ & $-0.08^{b}$ & $0.09^{a b}$ & $-0.12^{b}$ & $0.05^{\mathrm{b}}$ & $-0.12 \pm 0.09$ & $-0.17 \pm 0.09$ & $-0.07 \pm 0.09$ \\
\hline $\mathrm{EBE}^{4}$ change $(\mathrm{MJ})$ & $3.35^{a}$ & $1.61^{\mathrm{bc}}$ & $2.14^{\mathrm{ab}}$ & $1.01^{\mathrm{bcd}}$ & $0.94^{\mathrm{bcd}}$ & $0.61^{\mathrm{cd}}$ & $1.13^{\mathrm{bcd}}$ & $-0.07^{d}$ & $-1.10 \pm 0.33^{\star \star \star}$ & $-0.57 \pm 0.33$ & $-1.37 \pm 0.33^{* \star \star}$ \\
\hline \multicolumn{12}{|l|}{ Litters } \\
\hline \multicolumn{12}{|l|}{$17^{\text {th }}$ day of lactation } \\
\hline Litter size & 8.95 & 8.97 & 8.99 & 8.95 & 8.98 & 8.95 & 8.93 & 8.93 & $-0.01 \pm 0.04$ & -0.01 .04 & $-0.02 \pm 0.04$ \\
\hline Litter weight (g) & 2699 & 2709 & 2728 & 2729 & 2718 & 2729 & 2753 & 2689 & $-10 \pm 27$ & $11 \pm 27$ & $6 \pm 26$ \\
\hline \multicolumn{12}{|l|}{$17^{\text {th }}$ day of lactation to weaning } \\
\hline Feed intake ( $\mathrm{g}$ dry matter day $^{-1}$ ) & $88.3^{\mathrm{a}}$ & $87.5^{\mathrm{a}}$ & $76.8^{\mathrm{b}}$ & $71.6^{\mathrm{b}}$ & $68.6^{\mathrm{b}}$ & $68.3^{\mathrm{b}}$ & $52.5^{c}$ & $54.4^{c}$ & $-1.1 \pm 2.4$ & $-14.4 \pm 2.5^{\star \star \star}$ & $-20.1 \pm 2.4^{* * *}$ \\
\hline Digestible energy intake $\left(\mathrm{MJ}^{5}\right.$ day $\left.^{-1}\right)$ & $1.01^{\mathrm{a}}$ & $0.91^{\mathrm{b}}$ & $0.89^{\mathrm{b}}$ & $0.74^{c}$ & $0.74^{c}$ & $0.64^{\mathrm{cd}}$ & $0.56^{\text {de }}$ & $0.52^{\mathrm{e}}$ & $-0.10 \pm 0.03^{\star \star \star}$ & $-0.14 \pm 0.03^{\star \star \star}$ & $-0.27 \pm 0.03^{* \star \star}$ \\
\hline Crude protein intake ${ }^{6}\left(\mathrm{~g}_{\text {day }}{ }^{-1}\right)$ & $15.0^{\mathrm{a}}$ & $15.6^{\mathrm{a}}$ & $13.2^{\mathrm{b}}$ & $12.4^{\mathrm{b}}$ & $10.1^{c}$ & $9.7^{c}$ & $7.5^{\mathrm{d}}$ & $7.8^{d}$ & $-0.1 \pm 0.4$ & $-2.4 \pm 0.4^{* \star *}$ & $-5.3 \pm 0.4^{* \star \star}$ \\
\hline \multicolumn{12}{|l|}{ Weaning } \\
\hline Litter size & 8.91 & 8.90 & 8.92 & 8.88 & 8.89 & 8.84 & 8.86 & 8.85 & $-0.03 \pm 0.03$ & $-0.00 \pm 0.03$ & $-0.04 \pm 0.03$ \\
\hline Litter weight (g) & $5327^{a}$ & $5212^{a}$ & $5200^{a}$ & $5006^{b}$ & $4812^{c}$ & $4814^{c}$ & $4553^{d}$ & $4598^{d}$ & $-65 \pm 37$ & $-202 \pm 38^{\star \star \star}$ & $-492 \pm 37^{\star \star \star}$ \\
\hline
\end{tabular}

${ }^{1}$ First, second and third letters show acid detergent fibre (ADF), neutral detergent soluble fibre (NDSF) and crude protein (CP) levels (low, L; high, $H$ ), respectively.

${ }^{2} \mathrm{ADF}$ for starch: $[(\mathrm{HLH}+\mathrm{HHH}+\mathrm{HLL}+\mathrm{HHL}) / 4-(\mathrm{LLH}+\mathrm{LHH}+\mathrm{LLL}+\mathrm{LHL}) / 4] ; \quad \mathrm{NDSF}$ for starch: $[(\mathrm{LHH}+\mathrm{HHH}+\mathrm{LHL}+\mathrm{HHL}) / 4-(\mathrm{LLH}+\mathrm{HLH}+\mathrm{LLL}+\mathrm{HLL}) / 4] ; \quad \mathrm{CP} \quad$ reduction: $[(\mathrm{LLL}+\mathrm{HLL}+\mathrm{LHL}+\mathrm{HHL}) / 4-(\mathrm{LLH}+\mathrm{HLH}+\mathrm{LHH}+\mathrm{HHH}) / 4]$.

${ }^{3}$ Perirenal fat thickness.

${ }^{4}$ Estimated body energy using the equation provided by Pascual et al. (2004).

${ }^{5}$ As feed; digestible energy content calculated according Villamide et al. (2010) and Fundación Española para el Desarrollo de la Nutrición Animal (2010).

${ }^{6}$ As feed.

$* P<0.05 ; * * P<0.01 ; * * * P<0.001$

$\mathrm{a}, \mathrm{b}, \mathrm{c}, \mathrm{d}, \mathrm{e}$ Within a row, means not sharing any common superscript are significantly different $(P<0.05)$ 
Orthogonal contrasts were computed to test the differences due to replacement of starch with ADF $[(\mathrm{HLH}+\mathrm{HHH}+\mathrm{HLL}+\mathrm{HHL}) / 4 \quad-$ $(\mathrm{LLH}+\mathrm{LHH}+\mathrm{LLL}+\mathrm{LHL}) / 4]$, to replacement of starch with NDSF $[(\mathrm{LHH}+\mathrm{HHH}+\mathrm{LHL}+\mathrm{HHL}) / 4-(\mathrm{LLH}+\mathrm{HLH}+\mathrm{LLL}+\mathrm{HLL}) / 4]$ and to $\mathrm{CP}$ reduction $[(\mathrm{LLL}+\mathrm{HLL}+\mathrm{LHL}+\mathrm{HHL}) / 4-(\mathrm{LLH}+\mathrm{HLH}+\mathrm{LHH}+\mathrm{HHH}) / 4]$. Additional contrasts were performed to look for interactions between the $\mathrm{CP}$ content and the replacement of starch with ADF (high CP diets: $[(\mathrm{HLH}+\mathrm{HHH}) / 2-(\mathrm{LLH}+\mathrm{LHH} / 2]$; low CP diets: $[(\mathrm{HLL}+\mathrm{HHL}) / 2-(\mathrm{LLL}+\mathrm{LHL}) / 2])$ or the replacement of starch with NDSF (high CP diets: $[(\mathrm{LHH}+\mathrm{HHH}) / 2-(\mathrm{LLH}+\mathrm{HLH} / 2]$; low $\mathrm{CP}$ diets: $[(L H L+H H L) / 2-(L L L+H L L) / 2])$.

\section{Results}

\section{Lactation trial}

The effect of the experimental diets on the performance of rabbit does and litters from $17^{\text {th }}$ to $28^{\text {th }}$ day of lactation is shown in Table 3.

Feed intake of rabbit does increased when ADF replaced starch $(+7.0 \%$, $P<0.001)$, in spite of which digestible energy (DE) intake decreased $(-4.8 \%$, $P<0.001)$. The effects of this dietary variation on milk yield and PFT change depended on the CP content, as illustrated in Figure 1. Thus, this replacement impaired milk yield in high CP diets $\left(-15 \pm 6 \mathrm{~g} \mathrm{day}^{-1}, P<0.01\right)$ and not in low CP diets $\left(-3 \pm 6 \mathrm{~g} \mathrm{day}^{-1}, P>0.1\right)$. Although lower live weight increase of rabbit does from $17^{\text {th }}$ day of lactation to weaning was also observed when ADF replaced starch, the negative effect on PFT change was only observed in animals fed high $C P$ diets $(-0.41 \pm 0.13 \mathrm{~mm}, P<0.01)$, not in those fed low CP diets $(+0.17 \pm 0.13 \mathrm{~mm}, P>0.1)$; similarly, EBE change was only affected in animals fed high CP diets $(-1.43 \pm 0.46 \mathrm{MJ}, P<0.01)$, not in those fed low CP diets ($0.77 \pm 0.47 \mathrm{MJ}, P>0.1$ ). Litters showed similar feed intake but lower $D E$ intake as feed $(-12 \%, P<0.001)$ when ADF replaced starch. The overall effect of this replacement on litter weight at weaning was near to significance level 
$(P=0.08)$ because differences were recorded with high CP diets $(-154 \pm 52 \mathrm{~g}$, $P<0.01)$ and not with low CP diets $(+24 \pm 54 \mathrm{~g}, P>0.1)$, as illustrated in Figure 1 .

On the other hand, NDSF replacing starch reduced feed intake $(-6.6 \%$, $P<0.001)$, in an extent depending on the $\mathrm{CP}$ content, greater for high $\mathrm{CP}$ diets $\left(-34 \pm 6 \mathrm{~g} \mathrm{DM} \mathrm{day}^{-1}, P<0.001\right)$ than for low CP diets $\left(-19 \pm 7 \mathrm{~g} \mathrm{DM} \mathrm{day}^{-1}, P<0.01\right)$, as shown in Figure 2; as a consequence, this replacement decreased DE and CP intake of rabbit does $(-5.5 \%$ and $-7.4 \%$, respectively, $P<0.001)$, more extensively with high CP diets $\left(-0.33 \pm 0.07 \mathrm{MJ}^{\text {day }}{ }^{-1}, P<0.001 ;-6.2 \pm 1.0 \mathrm{~g}\right.$ day $^{-1}$, $P<0.001)$ than with low $\mathrm{CP}$ diets $\left(-0.15 \pm 0.07 \mathrm{MJ}^{\text {day }}{ }^{-1}, P<0.05 ;-3.4 \pm 1.1 \mathrm{~g} \mathrm{day}^{-1}\right.$, $P<0.01)$. This replacement also reduced milk yield $(-6.1 \%, P<0.001)$. Live weight increase, PFT change and EBE change of rabbit does throughout lactation were negatively affected when NDSF replaced starch in high CP diets $(-59 \pm 25 \mathrm{~g},-0.30 \pm 0.13 \mathrm{~mm}$ and $-0.9 \pm 0.4 \mathrm{MJ}$, respectively, $P<0.05)$ but not in low $C P$ diets $(-10 \pm 26 \mathrm{~g},-0.04 \pm 0.13 \mathrm{~mm}$ and $-0.2 \pm 0.5 \mathrm{MJ}$, respectively, $P>0.1)$, as illustrated in Figure 2 for PFT change. Litter feed intake (and, similarly, DE and CP intake as feed) and weight at weaning were reduced by NDSF replacing starch $(-19 \%$ and $-4.1 \%$, respectively, $P<0.001)$.

The reduction of $\mathrm{CP}$ content affected negatively feed, DE and, particularly, CP intake of rabbit does $(-5.6 \%,-13 \%$ and $-22 \%$, respectively, $P<0.001)$, as well as their milk yield $(-7.2 \%, P<0.001)$. Although live weight increase and EBE change of rabbit does from $17^{\text {th }}$ day of lactation to weaning were also lower when reducing $\mathrm{CP}$ content, this effect was not significant for PFT change, as a consequence of interactions above commented (Figures 1 and 2). Litter feed intake (and, similarly, DE and CP intake as fed) and weight at weaning were negatively affected by the reduction of CP content $(-25 \%$ and $-9.5 \%$, respectively, $P<0.001)$.

Throughout the trial, the mortality rate was $12 \%$ for rabbit does and negligible for suckling rabbits from $17^{\text {th }}$ to $28^{\text {th }}$ day of age (20 from a total of $2836,0.7 \%)$. 

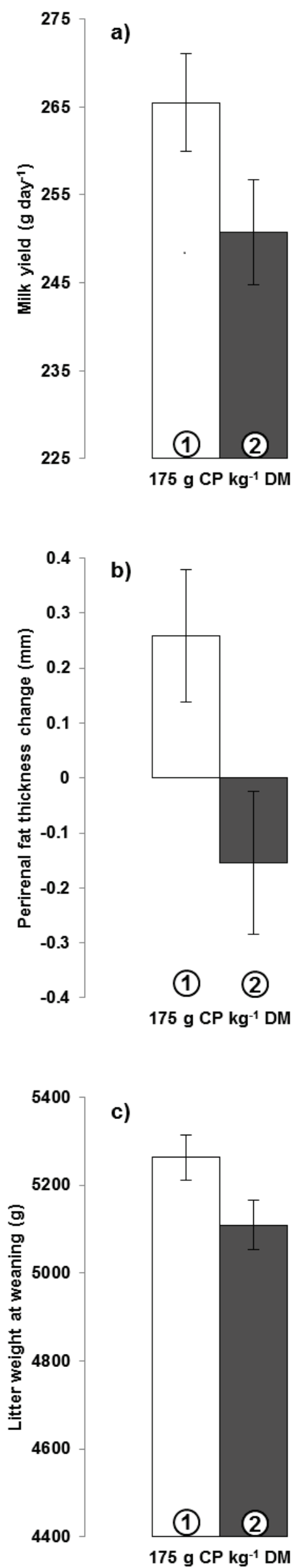

1 vs. 2: $P<0.01$

3 vs. $4: P>0.1$

1 vs. 3: $P<0.001$

2 vs. $4: P<0.05$

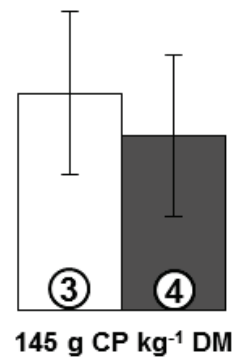

1 vs. 2: $P<0.01$

3 vs. $4: P>0.1$

1 vs. 3: $P<0.01$

2 vs. 4: $P>0.1$

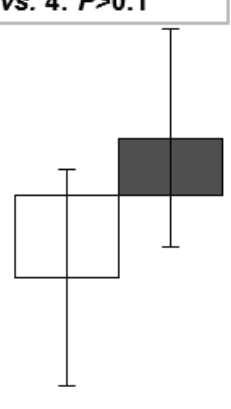

(3) (4)

$145 \mathrm{~g} \mathrm{CP} \mathrm{kg}^{-1} \mathrm{DM}$

1 vs. 2: $P<0.01$

3 vs. $4: P>0.1$

1 vs. 3: $P<0.001$

2 vs. 4: $P<0.001$

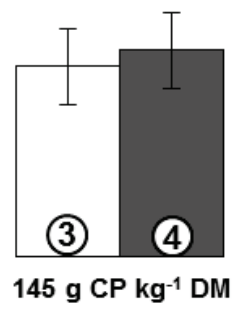

Figure 1. Interaction between the replacement of starch with acid detergent fibre (ADF) and the crude protein (CP) content on milk yield (a), perirenal fat thickness change (b) and litter weight at weaning (c). 1: more starch-less $A D F$ and high $C P$ diets (LLH and LHH); 2: less starch-more ADF and high $\mathrm{CP}$ diets $\mathrm{HLH}$ and $\mathrm{HHH})$; 3: more starch-less ADF and low CP diets (LLL and LHL); 4: less starch-more $A D F$ and low $C P$ diets (HLL and $H H L)$. 

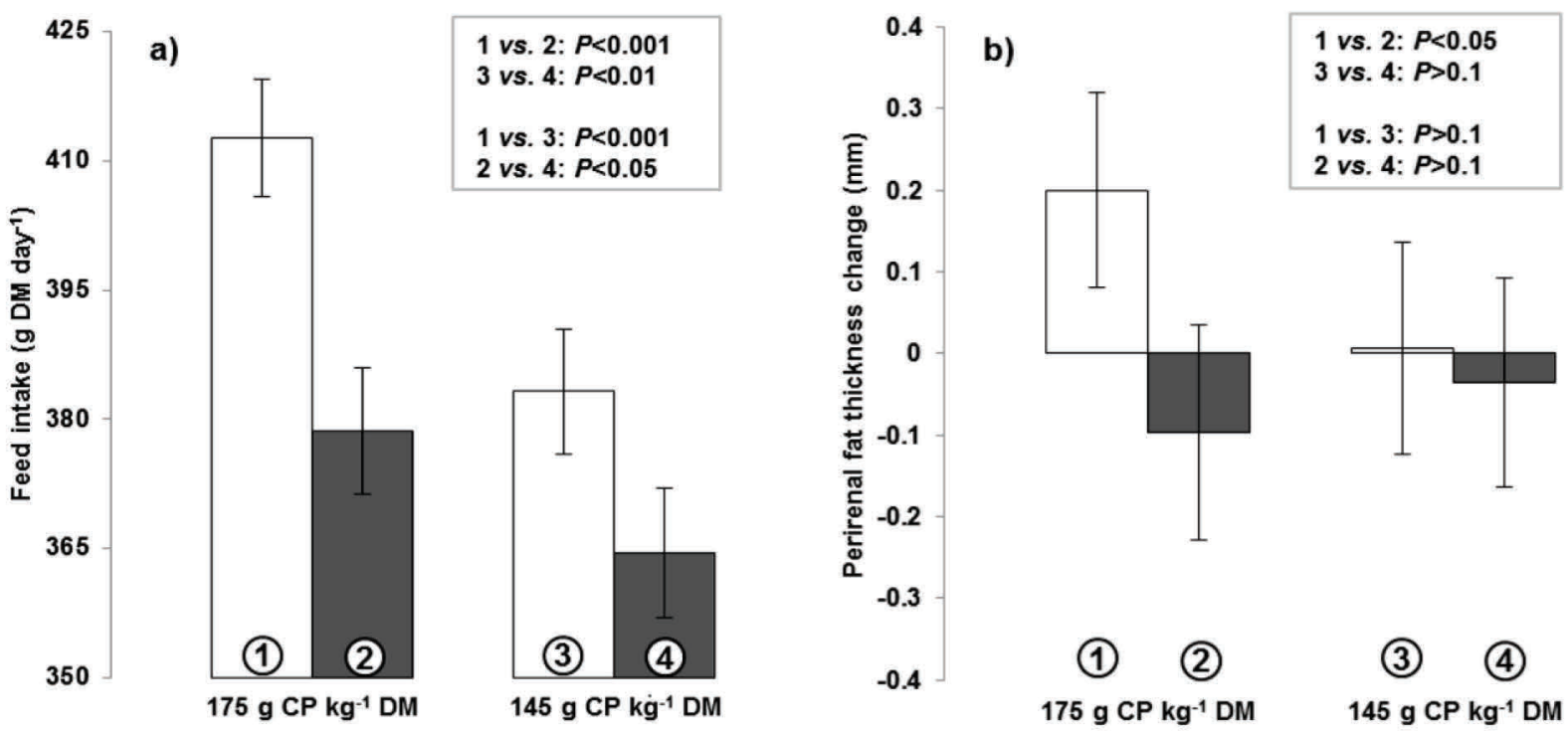

Figure 2. Interaction between the replacement of starch with neutral detergent soluble fibre (NDSF) and the crude protein (CP) content on feed intake (a) and perirenal fat thickness change (b). 1: more starch-less NDSF and high CP diets (LLH and $\mathrm{HLH}$ ); 2: less starch-more NDSF and high $\mathrm{CP}$ diets ( $\mathrm{LHH}$ and $\mathrm{HHH}) ; 3$ : more starch-less NDSF and low CP diets (LLL and HLL); 4: less starch-more NDSF and low $\mathrm{CP}$ diets (LHL and $\mathrm{HHL}$ )

\section{Growth trial}

Table 4 shows the effect of the experimental diets on the performance of growing rabbits reared in individual cages from weaning to 60 days of age.

From weaning to 49 days of age, the replacement of starch with ADF increased feed intake $(+13 \%, P<0.001)$ and reduced live weight gain $(-3.2 \%$, $P<0.05)$, the feed conversion rate (FCR) being so worsened $(+17 \%, P<0.001)$. After switching to commercial finishing diet, feed intake continued higher in animals previously fed more ADF-less starch diets $(+3.5 \%, P<0.01)$, which had higher live weight gain $(+4.1 \%, P<0.01)$ than those previously fed less ADFmore starch diets. 
Table 4. Effect of the weaning diet on performance of growing rabbits (individual cages)

\begin{tabular}{|c|c|c|c|c|c|c|c|c|c|c|c|}
\hline & \multicolumn{8}{|c|}{ Diet $^{1}$} & \multicolumn{3}{|c|}{ Contrast $^{2}$ (estimate \pm standard error) } \\
\hline & LLH & $\mathrm{HLH}$ & $\mathrm{LHH}$ & $\mathrm{HHH}$ & LLL & HLL & LHL & $\mathrm{HHL}$ & ADF for starch & NDSF for starch & $\mathrm{CP}$ reduction \\
\hline Number of rabbits ${ }^{3}$ & 41 & 38 & 42 & 42 & 46 & 43 & 47 & 49 & & & \\
\hline \multicolumn{12}{|l|}{28 to 49 days of age } \\
\hline $\begin{array}{l}\left.\text { Feed intake (g dry matter day }{ }^{-1}\right) \\
\text { Digestible energy intake }\left(\mathrm{MJ}^{4} \text { day }^{-1}\right) \\
\text { Crude protein intake }\left(\mathrm{g} \mathrm{day}^{-1}\right) \\
\text { Live weight gain }\left(\mathrm{g} \text { day }^{-1}\right) \\
\text { Feed conversion rate }\end{array}$ & $\begin{array}{l}112^{\mathrm{cd}} \\
1.27^{\mathrm{a}} \\
19.0^{\mathrm{c}} \\
55.1^{\mathrm{a}} \\
2.02^{\mathrm{d}}\end{array}$ & $\begin{array}{l}126^{\mathrm{a}} \\
1.30^{\mathrm{a}} \\
22.3^{\mathrm{a}} \\
53.5^{\mathrm{ab}} \\
2.35^{\mathrm{b}}\end{array}$ & $\begin{array}{l}108^{\mathrm{d}} \\
1.25^{\mathrm{a}} \\
18.4^{\mathrm{c}} \\
55.4^{\mathrm{a}} \\
1.95^{\mathrm{e}}\end{array}$ & $\begin{array}{l}116^{\mathrm{bc}} \\
1.22^{\mathrm{ab}} \\
20.7^{\mathrm{b}} \\
53.5^{\mathrm{ab}} \\
2.19^{\mathrm{c}}\end{array}$ & $\begin{array}{l}105^{\mathrm{e}} \\
1.13^{\mathrm{cd}} \\
15.4^{\mathrm{e}} \\
51.4^{\mathrm{bc}} \\
2.04^{\mathrm{d}}\end{array}$ & $\begin{array}{l}122^{\mathrm{ab}} \\
1.17^{\mathrm{bc}} \\
17.8^{\mathrm{d}} \\
49.6^{\mathrm{cd}} \\
2.45^{\mathrm{a}}\end{array}$ & $\begin{array}{c}98^{f} \\
1.06^{\mathrm{d}} \\
14.1^{\dagger} \\
48.9^{\mathrm{cd}} \\
1.98^{\mathrm{e}}\end{array}$ & $\begin{array}{l}112^{\mathrm{cd}} \\
1.10^{\mathrm{cd}} \\
16.4^{\mathrm{e}} \\
47.5^{\mathrm{d}} \\
2.39^{\mathrm{ab}}\end{array}$ & $\begin{array}{l}14 \pm 2^{* \star *} \\
0.02 \pm 0.02 \\
2.5 \pm 0.3^{* *} \\
-1.6 \pm 0.7^{\star} \\
0.34 \pm 0.02^{* \star *}\end{array}$ & $\begin{array}{l}-8 \pm 2^{\star * \star} \\
-0.06 \pm 0.02^{\star \star} \\
-1.2 \pm 0.3^{* \star \star} \\
-1.1 \pm 0.7 \\
-0.09 \pm 0.02^{* \star *}\end{array}$ & 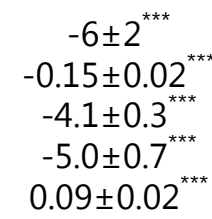 \\
\hline \multicolumn{12}{|l|}{49 to 60 days of $\mathrm{age}^{5}$} \\
\hline $\begin{array}{l}\text { Feed intake (g dry matter day }{ }^{-1} \text { ) } \\
\text { Live weight gain }\left(\mathrm{g} \mathrm{day}^{-1}\right) \\
\text { Feed conversion rate }\end{array}$ & $\begin{array}{l}159^{\mathrm{bc}} \\
50.8^{\mathrm{d}} \\
3.15^{\mathrm{ab}}\end{array}$ & $\begin{array}{l}166^{\mathrm{ab}} \\
54.8^{\mathrm{ab}} \\
3.01^{\mathrm{bc}}\end{array}$ & $\begin{array}{l}155^{\mathrm{c}} \\
50.5^{\mathrm{a}} \\
3.19^{\mathrm{a}}\end{array}$ & $\begin{array}{l}162^{\mathrm{abc}} \\
51.2^{\mathrm{cd}} \\
3.20^{\mathrm{a}}\end{array}$ & $\begin{array}{l}161^{\mathrm{abc}} \\
56.2^{\mathrm{ab}} \\
2.99^{\mathrm{c}}\end{array}$ & $\begin{array}{l}166^{a} \\
57.7^{a} \\
2.89^{c}\end{array}$ & $\begin{array}{l}157^{\mathrm{c}} \\
53.8^{\mathrm{bc}} \\
2.93^{\mathrm{c}}\end{array}$ & $\begin{array}{l}160^{a b c} \\
56.1^{a b} \\
2.90^{c}\end{array}$ & $\begin{array}{c}6 \pm 2^{\star *} \\
2.1 \pm 0.7^{\star \star} \\
-0.07 \pm 0.04\end{array}$ & $\begin{array}{c}-4 \pm 2^{*} \\
-2.0 \pm 0.7^{\star *} \\
0.05 \pm 0.04\end{array}$ & $\begin{array}{c}1 \pm 2 \\
4.1 \pm 0.7^{\text {** }} \\
-0.21 \pm 0.04^{* \star \star}\end{array}$ \\
\hline Live weight at 60 days of age $(\mathrm{g})$ & $2294^{\mathrm{ab}}$ & $2342^{\mathrm{a}}$ & $2264^{b c}$ & $2242^{b c}$ & $2219^{c}$ & $2210^{c d}$ & $2149^{\text {de }}$ & $2135^{\mathrm{e}}$ & $1 \pm 18$ & $-68 \pm 18^{\star \star \star}$ & $-107 \pm 18^{\star \star \star}$ \\
\hline
\end{tabular}

${ }^{1}$ First, second and third letters show acid detergent fibre (ADF), neutral detergent soluble fibre (NDSF) and crude protein (CP) levels (low, $\mathrm{L}$; high, $\mathrm{H}$ ), respectively.

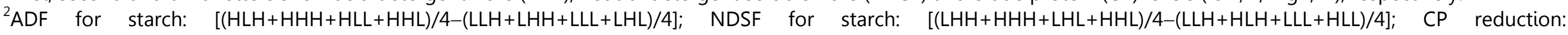
$[(\mathrm{LLL}+\mathrm{HLL}+\mathrm{LHL}+\mathrm{HHL}) / 4-(\mathrm{LLH}+\mathrm{HLH}+\mathrm{LHH}+\mathrm{HHH}) / 4]$.

${ }^{3}$ Alive at 60 days.

${ }^{4}$ Digestible energy content calculated according Villamide et al. (2010) and Fundación Española para el Desarrollo de la Nutrición Animal (2010).

${ }^{5}$ Commercial finishing diet.

${ }^{*} P<0.05 ;{ }^{* *} P<0.01 ; * * * P<0.001$

$a, b, c, d, e, f$ Within a row, means not sharing any common superscript are significantly different $(P<0.05)$ 
The inclusion of NDSF instead of starch reduced feed intake (and, similarly, DE and CP intake) from weaning to 49 days of age $(-6.7 \%, P<0.001)$, without affecting live weight gain in animals fed high CP diets $(0.1 \pm 1.1 \mathrm{~g}$ day $\left.^{-1}, P>0.1\right)$ but reducing it in those fed low CP diets $\left(-2.3 \pm 1.0 \mathrm{~g} \mathrm{day}^{-1}\right.$, $P<0.05)$, thus the FCR resulting improved more extensively with high $\mathrm{CP}$ diets $(-0.11 \pm 0.3, \quad P<0.001)$ than with low $C P$ diets $(-0.07 \pm 0.2, \quad P<0.01)$. After switching to commercial finishing diet, feed intake continued lower in animals previously fed more NDSF-less starch diets $(-2.7 \%, P<0.05)$, which had lower live weight gain $(-3.6 \%, P<0.01)$ than those previously fed less NDSF-more starch diets.

The reduction of $\mathrm{CP}$ content affected negatively feed, DE and, particularly, CP intake from weaning to 49 days of age $(-5.7 \%,-12 \%$ and $-21 \%$, respectively, $P<0.001)$, as well as live weight gain $(-9.2 \%, P<0.001)$ and $\mathrm{FCR}$ $(+4.0 \%, \quad P<0.001)$. After switching to commercial finishing diet, animals previously fed low $\mathrm{CP}$ diets had similar feed intake but improved live weight gain $(+8.0 \%, P<0.001)$ and $\operatorname{FCR}(-6.6 \%, P<0.001)$ compared with those previously fed high CP diets.

Finally, Table 5 shows the mortality rate registered in growing rabbits depending on the weaning diet. During the first 3 weeks after weaning mortality was high because of an ERE outbreak. Nevertheless, the three evaluated dietary variations (ADF replacing starch, NDSF replacing starch, CP reduction) led to lower mortality during this period $(-10.2,-15.1,-19.9 \%$, respectively, $P<0.001)$. No effects of the above mentioned strategies were detected on mortality rate after switching to commercial finishing diet. 
Table 5. Effect of the weaning diet on mortality rate of growing rabbits (collective and individual cages)

\begin{tabular}{|c|c|c|c|c|c|c|c|c|c|c|c|}
\hline & \multicolumn{8}{|c|}{ Diet $^{1}$} & \multicolumn{3}{|c|}{ Contrast $^{2}$ (estimate) } \\
\hline & LLH & $\mathrm{HLH}$ & $\mathrm{LHH}$ & $\mathrm{HHH}$ & LLL & HLL & LHL & $\mathrm{HHL}$ & ADF for starch & NDSF for starch & $\mathrm{CP}$ reduction \\
\hline Number of rabbits ${ }^{3}$ & 345 & 319 & 333 & 263 & 286 & 268 & 290 & 267 & & & \\
\hline \multicolumn{12}{|l|}{ Mortality rate (\%) } \\
\hline $\begin{array}{l}28 \text { to } 49 \text { days of age } \\
49 \text { to } 60 \text { days of age }\end{array}$ & $\begin{array}{c}71.6^{\mathrm{a}} \\
1.0\end{array}$ & $\begin{array}{c}68.3^{\mathrm{a}} \\
6.9\end{array}$ & $\begin{array}{c}58.6^{b} \\
6.5\end{array}$ & $\begin{array}{c}43.4^{\mathrm{cd}} \\
2.0\end{array}$ & $\begin{array}{c}51.4^{\mathrm{bc}} \\
5.8\end{array}$ & $\begin{array}{c}41.8^{\mathrm{d}} \\
1.3\end{array}$ & $\begin{array}{c}42.8^{d} \\
3.0\end{array}$ & $\begin{array}{c}29.2^{\mathrm{e}} \\
3.2\end{array}$ & $\begin{array}{l}-10.2^{\star \star \star} \\
-1.3\end{array}$ & $\begin{array}{l}-15.1^{\star \star \star} \\
-0.0\end{array}$ & $\begin{array}{l}-19.9^{\star \star \star} \\
-0.9\end{array}$ \\
\hline
\end{tabular}

${ }_{1}^{1}$ First, second and third letters show acid detergent fibre (ADF), neutral detergent soluble fibre (NDSF) and crude protein (CP) levels (low, $\mathrm{L}$; high, $\left.\mathrm{H}\right)$, respectively.

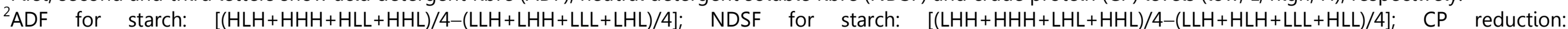

$[(\mathrm{LLL}+\mathrm{HLL}+\mathrm{LHL}+\mathrm{HHL}) / 4-(\mathrm{LLH}+\mathrm{HLH}+\mathrm{LHH}+\mathrm{HHH}) / 4]$

${ }^{3}$ Alive at 28 days.

${ }^{4}$ Commercial finishing diet.

$* * * P<0.001$

$a, b, c, d, e$ Within a row, means not sharing any common superscript are significantly different $(P<0.05)$ 


\section{Discussion}

\section{Replacement of starch with fibre}

In the current study, dietary starch was partially replaced with ADF or/and NDSF. Whatever the fibre nature is, the increase of fibre content at the expense of starch impairs dietary energy value and the general physiological response of rabbits to this effect includes an elevation of feed intake to meet energy requirements unless energy dilution is excessive (Xiccato and Trocino, 2010). However, other aspects concerning feed intake regulation must be considered. Between them, low-digestible fibre as cellulose and mainly lignin stimulates the intestinal rate of passage (Gidenne, 2003) which could promote feed intake, whereas soluble fibre as mainly pectins reduces feed intake, probably as consequence of its high water holding capacity to form gels in solution, higher gastric and caecal content weight and slower digestive transit (Fraga et al., 1991; Carabaño et al., 1997; Gidenne et al., 1998).

Below 11.7-12.2 MJ DE kg-1 DM, lactating rabbit does fed ad libitum reduce its DE intake as dietary content decreases (Xiccato and Trocino, 2010). The experimental diets used in the current study presented estimated DE contents below the indicated minimum and, in spite of increased feed intake, the calculated DE intake decreased when ADF replaced starch which impaired milk yield, as well as live weight, body reserves estimated by PFT and EBE balance with diets having $175 \mathrm{~g} \mathrm{CP} \mathrm{kg}^{-1}$ DM. However, with diets having $145 \mathrm{~g}$ $C P \mathrm{~kg}^{-1} \mathrm{DM}$ the effect on both milk yield and EBE balance was not significant (PFT even increased although not significantly), because protein instead of energy supply became limiting and increased feed intake as a result of ADF replacing starch turned out useful in sustaining milk yield and EBE balance by increasing protein intake.

On the other hand, feed intake of young rabbits before weaning does not fit the regulation pattern based on dietary DE content observed in rabbit does and weaned rabbits. Thus, it has been previously reported higher feed 
intake as a result of increasing its energy concentration both when milk intake remain unchanged (Fortun-Lamothe et al., 2001) or even increased (Debray et al., 2002). In the present study, litter feed intake was unaffected when ADF replaced starch (DE intake as feed being then reduced) and a negative effect on this trait might be hypothesized as a result of harder pellets $(+1.7 \pm 0.2 \mathrm{~kg}$, $+18 \%, P<0.001)$. Lower feed intake of young rabbits before weaning or early weaned has been reported when pellet hardness increased as a result of reducing pellet diameter (Gidenne et al., 2003; Maertens, 1994). Differences in litter weight at weaning as result of ADF replacing starch were essentially an expression of those observed in milk yield of rabbit does since nutrient supply in suckling rabbits from 17 to 28 days of age is basically provided by milk (Gallois et al., 2005) and, consequently, were detected only when using high $\mathrm{CP}$ diets.

Similarly to that occurred in lactating rabbit does, increased feed intake observed in weaned rabbits when ADF replaced starch was associated with impaired performance, even though the calculated DE intake was similar either expressed as absolute or relative to metabolic weight at 28 days of age $\left(+0.04 \pm 0.03 \mathrm{MJ} \mathrm{kg}^{-0.75} \mathrm{day}^{-1}, P>0.1\right)$, although it must be taken into account that calculated instead of measured dietary DE contents were applied. Nevertheless, Gidenne (2000) noted that growth rate decreases when dietary ADF is above $275 \mathrm{~g} \mathrm{~kg}^{-1}$ DM and all less starch-more ADF diets of the current study exceeded this limit (averaging $294 \mathrm{~g} \mathrm{~kg}^{-1} \mathrm{DM}$ ). Increased feed intake maintained after switching to finishing commercial diet (probably linked to greater gastrointestinal development) and completed compensatory growth led to lack of differences in live weight at 60 days of age as consequence of ADF replacing starch in weaning diets.

On the other hand, the replacement of starch with NDSF affected negatively feed intake of both lactating rabbit does and litters, as well as of weaned rabbits. The effect of high-digestible fibre replacing starch on feed intake is controversial. In growing rabbits, Trocino et al. (2011) have also reported lower feed intake as a consequence of replacing starch with soluble 
fibre (parallel increases of cellulose and insoluble hemicelluloses content accounted only for $14 \%$ of replaced starch). However, other studies reported no variation or even an increase of feed intake in growing rabbits having similar or faster hindgut transit when high-digestible fibre replaced starch (Gidenne and Bellier, 2000; Gidenne and Jehl, 1996; Gidenne and Perez, 2000; Perez et al., 2000). In the current study, the less starch-more NDSF diets had also slightly higher levels of cellulose and insoluble hemicelluloses (overall accounting for $28 \%$ of replaced starch), whereas in the above cited studies diets with increased high-digestible fibre had greater increments in content of cellulose and insoluble hemicelluloses (overall accounting for $40-60 \%$ of replaced starch). Greater increases of the content of these insoluble fibres in the diets richer in high-digestible fibre of these works could have induced higher feed intake, by diluting more extensively the dietary energy content or/and stimulating the rate of passage in the hindgut, especially if considering the low lignin levels of these diets (27 to $49 \mathrm{~g} \mathrm{~kg}^{-1} \mathrm{DM}$ ), compared with those of less starch-more NDSF diets in the current study (56 to $112 \mathrm{~g} \mathrm{~kg}^{-1} \mathrm{DM}$ ). On the other hand, with changes in levels of cellulose and insoluble hemicelluloses similar to those in the current study (overall accounting for $25 \%$ of replaced starch), Xiccato et al. (2011) have reported replacement of starch with soluble fibre having no effect on feed intake in growing rabbits; great differences in the ingredients involved to induce this replacement and in the analytical methodology to estimate soluble fibre could be hypothesized to explain the discrepancy with the current work, especially if taking into account the diversity of compounds included in the soluble fibre fraction.

The reduction of nutrient supply in lactating rabbit does when NDSF replaced starch would explain the impairment in milk yield. Live weight, body reserves estimated by PFT and EBE balance weakened with diets having $175 \mathrm{~g}$ $\mathrm{CP} \mathrm{kg}{ }^{-1} \mathrm{DM}$ but differences were not significant with those having $145 \mathrm{~g} \mathrm{CP}$ $\mathrm{kg}^{-1} \mathrm{DM}$, because of the difference in the extent of nutrient supply fall and the above mentioned limiting effect of protein intake. Less milk availability together lower nutrient supply as feed before weaning in litters receiving less 
starch-more NDSF diets led to an important decline in its weight at weaning compared with those receiving more starch-less NDSF diets.

The reduction in DE intake observed in weaned rabbits when NDSF replaced starch disappeared if expressed relative to metabolic weight at 28 days of age $\left(-0.01 \pm 0.03 \mathrm{MJ} \mathrm{kg}^{-0.75}\right.$ day $\left.^{-1}, P>0.1\right)$ and live weight gain was negatively affected only in animals fed low CP diets, because also in such a case protein intake became limiting and, moreover, CP intake relative to metabolic weight at 28 days of age decreased when NDSF replaced starch in low CP diets $\left(-1.2 \pm 0.5 \mathrm{~g} \mathrm{~kg}^{-0.75}\right.$ day $\left.^{-1}, P<0.05\right)$ and not in high $C P$ diets $\left(-0.1 \pm 0.6 \mathrm{~g} \mathrm{~kg}^{-0.75} \mathrm{day}^{-1}, \quad P>0.1\right)$. With diets having standard CP contents (166-182 g kg-1 DM), Trocino et al. (2011) and Xiccato et al. (2011) have found no effect on live weight gain when soluble fibre replaced starch. After switching to commercial finishing diet, lower live weight gain was observed in animals previously fed less starch-more NDSF diets, even though feed intake expressed relative to metabolic weight at 49 days of age was similar than in those previously fed more starch-less NDSF $\left(-0.5 \pm 1.4 \mathrm{~g} \mathrm{DM} \mathrm{kg}^{-0.75}\right.$ day $^{-1}$, $P>0.1$ ); this fact could be explained by live weight overestimating body weight at 49 days of age in animals fed these diets, since it is well established that soluble fibre increases digestive contents. Differences in live weight at 60 days of age as consequence of NDSF replacing starch in weaning diets reflected both lower weight at weaning and lower live weight gain during the full growth period.

Mortality rate during the growth trial was high, as usual in ERE outbreaks; values till 70-80\% had been reported (Le Bouquin et al., 2009; Rosell et al., 2000). Results of current study closely agree with those obtained in several works recently reviewed by Blas and Gidenne (2010) indicating that, even if dietary fibre meets essentially the requirements proposed by Gidenne and García (2006) to prevent digestible troubles in young rabbits during postweaning period, increasing levels of low- or high-digestible fibre replacing starch reduce mortality rate in a context of ERE. The beneficial effect of both 
replacements seems to be additive, since reduction in mortality rate was stronger when made simultaneously.

\section{Reduction of CP content}

The reduction of CP content from 175 to $145 \mathrm{~g} \mathrm{~kg}^{-1}$ DM produced a decrease in feed intake of both lactating rabbit does and litters, as well as of weaned rabbits. Prasad and Karim (1998) also found this effect in lactating rabbit does when comparing diets with 186 or $152 \mathrm{~g} \mathrm{CP} \mathrm{kg}^{-1}$ DM. Similarly, Martínez-Vallespín et al. (2008) observed a reduction in feed intake of lactating rabbit does, litters and weaned rabbits in a previous work where standard and reduced protein levels were compared (123 and $93 \mathrm{~g}$ digestible protein $\mathrm{kg}^{-1} \mathrm{DM}$, respectively), also reported in lactating rabbit does by Partridge and Allan (1982) when comparing diets with 175 or $135 \mathrm{~g} \mathrm{CP} \mathrm{kg}^{-1}$ $D M$; however, in both studies, level of ADF differed among diets being lower in those with less protein. On the other hand, no effect on feed intake was observed as a result of reducing CP content from 201 to $175 \mathrm{~g} \mathrm{~kg}^{-1}$ DM in lactating rabbit does and litters (García-Palomares et al., 2006a) or from 175 to $154 \mathrm{~g} \mathrm{~kg}^{-1}$ DM in weaned rabbits (García-Palomares et al., 2006b). The role of dietary protein content in controlling voluntary feed intake is complex and incompletely understood (Tome, 2004). Forbes (1995) noted that voluntary feed intake is not affected by protein content within the normal range, but it is depressed by diets of too low protein, as well as by imbalance, deficiency or excess of essential amino acids. In the current study, diets with $145 \mathrm{~g} \mathrm{CP} \mathrm{kg}^{-1}$ DM might pass the critical limit in protein content causing a reduction of feed intake secondary to lower performance and, moreover, they had similar content in total lysine, sulphur amino acids, threonine and tryptophan (respectively, 11.3-11.7, 8.1-8.4, 8.0-8.3 and 3.7-3.8 g kg-1 DM, calculated according Fundación Española para el Desarrollo de la Nutrición Animal, 2010) but higher in added DL-methionine, L-threonine and L-tryptophan than diets with $175 \mathrm{~g} \mathrm{CP} \mathrm{kg}^{-1}$ DM (averaging 4.13 vs. $1.13,3.50$ vs. 1.50 and 2.25 vs. $1.50 \mathrm{~g}$ $\mathrm{kg}^{-1} \mathrm{DM}$, respectively). An excess of added DL-methionine has been reported to depress feed intake in suckling and weaned rabbits (Colin et al., 1973; 
Gidenne et al., 2002), although using higher addition levels (>8 $\mathrm{g} \mathrm{kg}^{-1} \mathrm{DM}$ ). Added amino acids are more rapidly available than those constituting dietary protein and, since the ability of animals to store amino acids in excess of immediate requirements is very limited and they must be available at the same time, this imbalance might produce both higher concentration in blood having central satiating effect and lower performance, causing respectively primary and secondary reduction of feed intake (Forbes, 1995); besides, essential amino acids other than those mentioned above could become limiting in diets having only $145 \mathrm{~g} \mathrm{CP} \mathrm{kg}^{-1} \mathrm{DM}$.

The reduction of nutrient supply, particularly protein, in lactating rabbit does when fed low CP diets impaired milk yield. Less milk availability and reduction in $D E$ and, especially, protein intake as feed before weaning in litters receiving diets having $145 \mathrm{~g} \mathrm{CP} \mathrm{kg}^{-1} \mathrm{DM}$ led to large reduction in their weight at weaning compared with those having $175 \mathrm{~g} \mathrm{CP} \mathrm{kg}^{-1} \mathrm{DM}$. Current recommendations in diets for lactating rabbits does are $>185 \mathrm{~g} \mathrm{CP} \mathrm{kg}^{-1} \mathrm{DM}$ (De Blas and Mateos, 2010; Xiccato and Trocino, 2010), although GarcíaPalomares et al. (2006a) found no negative effects on performance of does and suckling rabbits when reducing dietary protein content to $175 \mathrm{~g} \mathrm{CP} \mathrm{kg}^{-1}$ DM in late lactation.

Reduced feed intake in weaned rabbits fed diets with $145 \mathrm{~g} \mathrm{CP} \mathrm{kg}^{-1} \mathrm{DM}$ disappeared if expressed relative to metabolic weight at 28 days of age $\left(+0.0 \pm 2.4 \mathrm{~g} \mathrm{DM} \mathrm{kg}^{-0.75}\right.$ day $\left.^{-1}, P>0.1\right)$ but reduction in DE and, especially, CP intake remained $\left(-0.13 \pm 0.03 \mathrm{MJ} \mathrm{kg}^{-0.75}\right.$ day $^{-1},-6.7 \%, P<0.001 ;-4.9 \pm 0.4 \mathrm{~g} \mathrm{~kg}^{-0.75}$ day $\left.^{-1},-16 \% ; P<0.001\right)$, leading to great reduction in live weight gain compared with those fed diets with $175 \mathrm{~g} \mathrm{CP} \mathrm{kg}^{-1} \mathrm{DM}$. Current recommendations in diets for growing rabbits are $>165 \mathrm{~g} \mathrm{CP} \mathrm{kg}^{-1}$ DM (De Blas and Mateos, 2010; Xiccato and Trocino, 2010), although García-Palomares et al. (2006b) found no negative effects on growth performance when reducing protein content to $154 \mathrm{~g} \mathrm{CP} \mathrm{kg}^{-1}$ DM. After switching to commercial finishing diet, higher feed intake as expressed relative to metabolic weight at 49 days of age $(+7.5 \pm 1.4 \mathrm{~g}$ DM $\mathrm{kg}^{-0.75}$ day $\left.^{-1},+7.0 \%, \quad P<0.001\right)$ allowed compensatory growth still 
incomplete at 60 days of age, in such a way that differences in live weight at this age as consequence of reducing CP content in weaning diets reflected both lower weight at weaning and lower live weight gain during the full growth period.

As in the current study, reduction on mortality rate of young rabbits after weaning by reducing CP content as been also reported by Chamorro et al. (2007) comparing diets with 207 and $176 \mathrm{~g} \mathrm{CP} \mathrm{kg}^{-1}$ DM, as well as by Carabaño et al. (2009) comparing diets with 177 and $155 \mathrm{~g} \mathrm{CP} \mathrm{kg}^{-1} \mathrm{DM}$. The positive effect of this dietary change seems to be additive to those induced by ADF or/and NDSF fibre replacing starch and mortality rate was lowest in the diet which accumulated the three dietary changes $(\mathrm{HHL})$.

\section{Conclusion}

The partial replacement of starch with ADF or with NDSF or the reduction

of $C P$ content from 175 to $145 \mathrm{~g} \mathrm{~kg}^{-1}$ DM in weaning diets for lactating rabbit does in late lactation and young rabbits around weaning, impaired milk yield and body condition of does, as well as litter weight at weaning, although the negative effect of replacing starch with ADF was only observed in the high CP diets; moreover, growth during post-weaning period also decreased. However, in an ERE context, mortality rate during this period was reduced by these three dietary changes, which effects seemed additive.

Acknowledgement: Financial support was provided by the Spanish Ministerio de Educación y Ciencia (Proyecto AGL2006-07596).

\section{References}

AOAC, 2000. Official methods of analysis of the AOAC International, $17^{\text {th }}$ ed., AOAC International, Gaithersburg, MD (USA).

Batey, I.L., 1982. Starch analysis using thermostable alpha-amylases. Starch/Stärke 34, 125-128. 
Blas, E., Gidenne, T., 2010. Digestion of sugars and starch. In: De Blas, C., Wiseman, J. (Eds.), Nutrition of the Rabbit, $2^{\text {nd }}$ ed., $C A B$ International, Wallingford (UK), pp. 19-38.

Boletín Oficial del Estado, 2005. Real Decreto 1201/2005 sobre protección de los animales utilizados para experimentación y otros fines científicos. BOE 242, 34367-34391.

Carabaño, R., Motta-Ferreira, W., De Blas, J.C., Fraga, M.J., 1997. Substitution of sugarbeet pulp for alfalfa hay in diets for growing rabbits. Anim. Feed Sci. Technol. 65, 249-256.

Carabaño, R., Villamide, M.J., García, J., Nicodemus, N., Llorente, A., Chamorro, S., Menoyo, D., García-Rebollar, P., García-Ruiz, A.I., De Blas, J.C., 2009. New concepts and objectives for protein-amino acid nutrition in rabbits: a review. World Rabbit Sci. 17, 1-14.

Chamorro, S., Gómez-Conde, M.S., Pérez de Rozas, A.M., Badiola, I., Carabaño, R., De Blas, J.C., 2007. Effect on digestion and performance of dietary protein content and of increased substitution of lucerne hay with soyabean protein concentrate in starter diets for young rabbits. Animal 1 , 651-659.

Colin, M., Arkhurts G., Lebas F., 1973. Effets de l'addition de méthionine au régime alimentaire sur les performances de croissance chez le lapin. Ann. Zootech. 22, 485-491.

De Blas, C., Mateos, G.G., 2010. Feed formulation, in: De Blas, C., Wiseman, J. (Eds.), Nutrition of the Rabbit, $2^{\text {nd }}$ ed., $C A B$ International, Wallingford (UK), pp. 222-232.

De Blas, C., García, J., Carabaño, R., 1999. Role of fibre in rabbit diets. A review. Ann. Zootech. 48, 3-13.

Debray, L., Fortun-Lamothe, L., Gidenne, T., 2002. Influence of low dietary starch/fibre ratio around weaning on intake behaviour, performance and health status of young and rabbit does. Anim. Res. 51, 63-75. 
Fernández-Carmona, J., Blas, E., Pascual, J.J., Maertens, L., Gidenne, T., Xiccato, G., García, J., 2005. Recommendations and guidelines for applied nutrition experiments in rabbits. World Rabbit Sci. 13, 209-228.

Forbes, J.M., 1995. Specific nutrients affecting intake. In: Forbes J.M. (Ed.), Voluntary food intake and diet selection in farm animals, CAB International, Wallingford (UK), pp. 226-246.

Fortun-Lamothe, L., Gidenne, T., Lapanouse, A., De Dapper, J., 2000. Note: an original system to separately control litter and female feed intake without modification of the mother-young relations. World Rabbit Sci. 8, 177-180.

Fortun-Lamothe, L., Gidenne, T., Chalaye, F., Debray, L., 2001. Stratégie d'alimentation autour du sevrage chez le lapin: effets du ratio amidon/fibres. Proc. $9^{\text {émes }}$ Journées de la Recherche Cunicole, Paris (France), 195-198.

Fraga, M.J., Pérez de Ayala, P., Carabaño, R., De Blas, J.C., 1991. Effect of type of fiber on the rate of passage and on the contribution of soft feces to nutrient intake of finishing rabbits. J. Anim. Sci. 69, 1566-1574.

Fundación Española para el Desarrollo de la Nutrición Animal, 2010. Tablas FEDNA de composición y valor nutritivo de alimentos para la fabricación de piensos compuestos, $3^{a}$ ed., De Blas, C., Mateos, G.G., García-Rebollar, P. (coord.). FEDNA, Madrid (Spain).

Gallois, M., Gidenne, T., Fortun-Lamothe, L., Le Huerou-Luron, I., Lallès, J.P., 2005. An early stimulation of solid feed intake slightly influences the morphological gut maturation in the rabbit. Reprod. Nutr. Dev. 45, 109122.

García-Palomares, J., Carabaño, R., García-Rebollar, P., De Blas, J.C., GarcíaRuiz, A.I., 2006a. Effects of a dietary protein reduction during weaning on the performance of does and suckling rabbits. World Rabbit Sci. 14, 2326. 
García-Palomares, J., Carabaño, R., García-Rebollar, P., De Blas, J.C., Corujo, A., García-Ruiz, A.I., 2006b. Effects of a dietary protein reduction and enzyme supplementation on growth performance in the fattening period. World Rabbit Sci. 14, 231-236.

Gidenne, T., 2000. Recent advances in rabbit nutrition: emphasis on fibre requirements. A review. World Rabbit Sci. 8, 23-32.

Gidenne, T., 2003. Fibres in rabbit feeding for digestive troubles prevention: respective role of low-digested and digestible fibre. Livest. Prod. Sci. 81, 105-117.

Gidenne, T., Bellier, R., 2000. Use of digestible fibre in replacement to available carbohydrates. Effect on digestion, rate of passage and caecal fermentation pattern during the growth of the rabbit. Livest. Prod. Sci. 63, 141-152.

Gidenne, T., García, J., 2006. Nutritional strategies improving the digestive health of the weaned rabbit. In: Maertens, L., Coudert, P. (Eds.), Recent Advances in Rabbit Sciences, ILVO, Melle (Belgium), pp. 229-238.

Gidenne, T., Jehl, N., 1996. Replacement of starch by digestible fibre in the feed for the growing rabbit. 1. Consequences for digestibility and rate of passage. Anim. Feed Sci. Technol. 61, 183-192.

Gidenne, T., Perez, J.M., 2000. Replacement of digestible fibre by starch in the diet of the growing rabbit. I. Effects on digestion, rate of passage and retention of nutrients. Ann. Zootech. 49, 357-368.

Gidenne, T., Carabaño, R., García, J., De Blas, C., 1998. Fibre digestion. In: De Blas, C., Wiseman, J. (Eds.), Nutrition of the Rabbit, CAB International, Wallingford (UK), pp. 69-101.

Gidenne, T., Jehl, N., Segura, M., Michalet-Doreau, B., 2002. Microbial activity in the caecum of the rabbit around weaning: impact of a dietary fibre deficiency and of intake level. Anim. Feed Sci. Technol. 99, 107-118. 
Gidenne, T., Lapanouse, A., Fortun-Lamothe, L., 2003. Comportement alimentaire du lapereau sevré précocement: effect du diamètre du granule. Proc. $10^{\text {émes }}$ Journées de la Recherche Cunicole, Paris (France), 17-19.

Gidenne, T., García, J., Lebas, F., Licois, D., 2010. Nutrition and feeding strategy: interactions with pathology. In: De Blas, C., Wiseman, J. (Eds.), Nutrition of the Rabbit, $2^{\text {nd }}$ ed., CAB International, Wallingford (UK), pp. 179-199.

Hall, M.B., Lewis, B.A., Van Soest, P.J., Chase, L.E., 1997. A simple method for estimation of neutral detergent-soluble fibre. J. Sci. Food Agric. 74, 441449.

Le Bouquin, S., Robert, J.L., Larour, G., Balaine, L., Eono, F., Boucher, S., Huneau, A., Michel, V., 2009. Risk factors for an acute expression of Epizootic Rabbit Enteropathy syndrome in rabbits after weaning in French kindling-to-finishing farms. Livest. Sci. 125, 283-290.

Maertens. L., 1994. Influence du diamètre du granulé sur les performances des lapareaux avant sevrage. Proc. $6^{\text {émes }}$ Journées de la Recherche Cunicole, Paris (France), pp. 325-332.

Martínez-Vallespín, B., Murillo, M., Martínez-Paredes, E., Ródenas, L., Blas, E., Cervera, C., 2008. Utilización de piensos peridestete con bajo contenido en proteína. Proc. XXXIII Symposium de Cunicultura (ASESCU), Calahorra (Spain), pp. 70-73.

Partridge, G.G., Allan, S.J., 1982. The effects of different intakes of crude protein on nitrogen utilization in the pregnant and lactating rabbit. Anim. Prod. 35, 145-155.

Pascual, J.J., Castella, F., Cervera, C., Blas, E., Fernández-Carmona, J., 2000. The use of ultrasound measurements of perirenal fat thickness to estimate changes in body condition of young female rabbits. Anim. Sci. 70, 435442. 
Pascual, J.J., Blanco, J., Piquer, O., Quevedo, F., Cervera, C., 2004. Ultrasound measurements of perirenal fat thickness to estimate the body condition of reproductive rabbit does in different physiological states. World Rabbit Sci. 12, 7-21.

Perez, J.M., Gidenne, T., Bouvarel, I., Arveux, P., Bourdillon, A., Briens, C., Le Naour, J., Messager, B., Mirabito, L., 2000. Replacement of digestible fibre by starch in the diet of the growing rabbit. II. Effects on performances and mortality by diarrhoea. Ann. Zootech. 49, 369-377.

Prasad, R., Karim, S.A., 1998. Effect of dietary energy and protein level on performance and digestibility parameters in pregnant and in lactating rabbit does under tropical environment. World Rabbit Sci. 6, 271-276.

Rosell, J.M., Cuervo, L., Argüello, J.L, Badiola, J.I., Blas, E., 2000. Enteropatía mucoide. In: Rosell, J.M. (Ed), Enfermedades del Conejo (vol. II), MundiPrensa (Spain), pp. 248-263.

Statistical Analysis Systems Institute, 2002. User's guide, Release 9.1. SAS Institute Inc, Cary, NC (USA).

Tome, D., 2004. Protein, amino acids and the control of food intake. Br. J. Nutr. 92, S27-S30.

Trocino, A., Fragkiadakis, M., Majolini, D., Carabaño, R., Xiccato, G., 2011. Effect of the increase of dietary starch and soluble fibre on digestive efficiency and growth performance of meat rabbits. Anim. Feed Sci. Technol. 165, 265-277.

Van Soest, P.J., Robertson, J.R., Lewis, B.A., 1991. Methods for dietary fiber, neutral detergent fiber and nonstarch polysaccharides in relation to animal nutrition. J. Dairy Sci. 74, 3583-3597.

Villamide, M.J., Maertens, L., De Blas C., 2010. Feed evaluation. In: De Blas, C., Wiseman, J. (Eds.), Nutrition of the Rabbit, $2^{\text {nd }}$ ed., CAB International, Wallingford (UK), pp. 151-162. 
Xiccato, G., Trocino, A., 2010. Energy and protein metabolism and requirements. In: De Blas, C., Wiseman, J. (Eds.), Nutrition of the Rabbit, $2^{\text {nd }}$ ed., $C A B$ International, Wallingford (UK), pp. 83-118.

Xiccato, G., Trocino, A., Majolini, D., Fragkiadakis, M., Tazzoli, M., 2011. Effect of decreasing dietary protein level and replacing starch with soluble fibre on digestive physiology and performance of growing rabbits. Animal 5, 1179-1187. 


\section{EXPERIMENT II}





\title{
Partial replacement of starch with acid detergent fibre or/and neutral detergent soluble fibre at two protein levels: effects on ileal apparent digestibility and caecal environment of growing rabbits
}

B. Martínez-Vallespín, E. Martínez-Paredes, L. Ródenas, V.J. Moya, C. Cervera, J.J. Pascual, E. Blas

Institute of Animal Science and Technology. Universidad Politécnica de Valencia, Camino de Vera s/n. 46022 Valencia, Spain.

\begin{abstract}
To evaluate the effects of the composition of weaning diets both on ileal apparent digestibility and caecal environment in growing rabbits, eight experimental diets were formulated according to a factorial design $2 \times 2 \times 2$, the three factors being: i) partial replacement of starch with acid detergent fibre (ADF), ii) partial replacement of starch with neutral detergent soluble fibre (NDSF) and iii) reduction of crude protein (CP) content from 175 to $145 \mathrm{~g} / \mathrm{kg}$ DM. A total of 32 litters of 8 kits were randomly assigned to the experimental diets at 17 days of age, weaned at 28 days of age and slaughtered at 35 days of age to collect samples of ileal and caecal contents. The substitution of ADF for starch reduced the coefficient of ileal apparent digestibility (CIAD) of dry matter (DM) (0.292 vs. 0.229, $P<0.01)$. The substitution of NDSF for starch reduced CIAD of DM (0.277 vs. 0.244, $P=0.09)$ and $\mathrm{CP}(0.574$ vs. $0.529, P=0.07)$, while increased CIAD of NDSF $(-0.040$ vs. $0.099, P<0.01)$. The reduction of $C P$ content decreased CIAD of DM (0.277 vs. $0.244, P=0.09), \mathrm{CP}(0.578$ vs. 0.525 , $P<0.05)$ and NDSF $(0.086 v s .-0.038, P<0.01)$. On the other hand, an interaction between ADF (230 or $290 \mathrm{~g} / \mathrm{kg}$ DM) and NDSF (145 or $185 \mathrm{~g} / \mathrm{kg} \mathrm{DM}$ ) levels
\end{abstract}


was detected affecting caecal weight (relative to live weight), as well as DM content and $\mathrm{pH}$ of caecal digesta. Thus, the increase of ADF in high NDSF diets reduced caecal weight $(-0.009 \pm 0.003, P<0.01)$, increased DM content of caecal digesta $(+31 \pm 4 \mathrm{~g} / \mathrm{kg}, \quad P<0.001)$ and reduced caecal $\mathrm{pH}(-0.10 \pm 0.04$, $P<0.05)$; in the case of low NDSF diets, higher ADF increased DM content of caecal digesta in a less extent $(+16 \pm 4 \mathrm{~g} / \mathrm{kg}, P<0.001)$ and increased caecal $\mathrm{pH}$ $(+0.08 \pm 0.04, P<0.05)$. The increase of NDSF in high ADF diets increased caecal weight $(+0.009 \pm 0.003, P<0.01)$ and reduced caecal $\mathrm{pH}(-0.14 \pm 0.04, P<0.001)$; in the case of low ADF diets, higher NDSF increased caecal weight more extensively $(+0.015 \pm 0.003, \quad P<0.001)$ and reduced $D M$ content of caecal digesta $(-16 \pm 5 \mathrm{~g} / \mathrm{kg}, P<0.001)$. Both ADF and NDSF replacing starch increased total volatile fatty acids (VFA) concentration of caecal digesta $(+11.5 \%$ and $+13.9 \%$, respectively, $P<0.01)$; the replacement with NDSF increased molar proportion of butyrate $(0.095 \mathrm{vs} .0 .112, P<0.001)$ at the expense of mainly acetate $(0.841$ vs. $0.820, P<0.001)$ and reduced ammonia concentration of caecal digesta $(-8.1 \%, P<0.05)$. The CP reduction decreased total VFA $(-14.4 \%$, $P<0.001)$ and ammonia $(-23.5 \%, P<0.001)$ concentrations of caecal digesta and increased caecal $\mathrm{pH}(5.87$ vs. 5.93, $P<0.05)$. Overall, the three dietary changes under study led to changes in caecal environment which can be considered as favourable for digestive health.

Keywords: growing rabbit, ileal apparent digestibility, caecal environment, fibre, starch, protein. 


\section{Introduction}

The incidence of digestive disorders during the growth period in rabbit commercial farms has encouraged the research on specific diets for the period around weaning. In the last years, constant efforts have been done to establish the nutrient requirements for promoting digestive health in growing rabbits, studying how some dietary fractions influence the development of the gastrointestinal tract and the caecal microbial ecosystem. The level and type of fibre, starch or protein are frequently concerned, although their respective effects are sometimes difficult to elucidate because dietary changes are usually complex and involve several nutrients.

Beneficial effect of increasing dietary fibre replacing starch on digestive health of growing rabbits is well established (De Blas et al., 1999; Gidenne and García, 2006; Blas and Gidenne, 2010; Gidenne et al., 2010b; MartínezVallespín et al., 2011). Depending on if low-digestible fibre (lignin, cellulose) or high-digestible fibre (pectins, hemicelluloses) are involved, promoted rate of passage of digesta in the caeco-colic segment or favourable changes in carbohydrate substrate for microbiota, fermentative activity and caecal environment are mainly concerned. Reduction of dietary crude protein content has also positive effect on digestive health of growing rabbits (Carabaño et al., 2009; Martínez-Vallespín et al., 2011). This reduction has been related with lower ileal flow of nitrogen and caecal Clostridium perfringens population (Chamorro et al., 2007).

With this background, the present work aims to evaluate, in a factorial design, the effects of partial replacement of starch with acid detergent fibre (ADF), partial replacement of starch with neutral detergent soluble fibre (NDSF) and reduction in crude protein (CP) content in the weaning diet both on ileal apparent digestibility and caecal environment in growing rabbits. 


\section{Material and Methods}

\section{Diets}

Eight experimental weaning diets were formulated according to a factorial design $2 \times 2 \times 2$. The factors were the replacement of $50 \mathrm{~g} / \mathrm{kg}$ dry matter (DM) of starch with ADF, the replacement of $50 \mathrm{~g} / \mathrm{kg}$ DM of starch with NDSF and the reduction of CP content from 175 to $145 \mathrm{~g} / \mathrm{kg} \mathrm{DM}$; this design allowed to compare all the combinations of these factors $(\mathrm{LLH}, \mathrm{HLH}, \mathrm{LHH}$, $H H H, L L L, H L L, L H L$ and $H H L)$, where the first, second and third letters were respectively the dietary ADF, NDSF and CP contents (low or high; $L$ or $H$ ).

Ingredient and chemical composition of the experimental diets are shown in Tables 1 and 2, respectively. Starch was replaced by ADF mainly by reducing wheat grain $(-90 \mathrm{~g} / \mathrm{kg} \mathrm{DM})$, wheat bran $(-40 \mathrm{~g} / \mathrm{kg} \mathrm{DM})$ and grape pomace $(-70 \mathrm{~g} / \mathrm{kg} \mathrm{DM})$ and increasing oat hulls (+60 g/ $\mathrm{kg} \mathrm{DM})$ and defatted grape seed (+130 g/kg DM); starch was replaced by NDSF mainly by reducing wheat grain (-90 g/kg DM), soybean hulls $(-40 \mathrm{~g} / \mathrm{kg} \mathrm{DM})$ and treated wheat straw (-80 g/kg DM) and increasing beet pulp (+170 g/kg DM) and oat hulls (+50 g/kg DM); CP content was reduced mainly by replacing sunflower meal $(-360$ or $-355 \mathrm{~g} / \mathrm{kg} \mathrm{DM})$ with soybean protein concentrate $(+75 \mathrm{~g} / \mathrm{kg} \mathrm{DM})$, beet pulp (+60 g/kg DM), defatted grape seed (+60 g/ $/ \mathrm{kg} \mathrm{DM})$ and treated wheat straw $(+130$ or $+127.5 \mathrm{~g} / \mathrm{kg} \mathrm{DM})$. All the experimental diets included $5 \mathrm{~g} / \mathrm{kg}$ DM of alfalfa hay marked with ytterbium according to García et al. (1999), as well as zinc bacitracin (100 ppm) and robenidine (66 ppm).

\section{Animals and housing}

A total of 32 litters (maternal line $A \times$ growth line $\mathrm{R}$, from Universidad Politécnica de Valencia, Spain) were standardized to 8 kits at 17 days of age transferring the remainder kits to nursing does. From that day forward, litters (and their mothers) received one of the experimental diets, randomly assigned (4 litters/diet). Litters were weaned at 28 days of age and slaughtered at 35 days of age to collect samples of ileal and caecal contents. 
Table 1. Ingredient composition of the experimental diets ( $\mathrm{g} / \mathrm{kg}$ dry matter)

\begin{tabular}{|c|c|c|c|c|c|c|c|c|}
\hline Diets & LLH & $\mathrm{HLH}$ & $\mathrm{LHH}$ & $\mathrm{HHH}$ & LLL & HLL & $\mathrm{LHL}$ & $\mathrm{HHL}$ \\
\hline \multicolumn{9}{|l|}{ Nutrient level $^{1}$} \\
\hline Acid detergent fibre & L & $\mathrm{H}$ & L & $\mathrm{H}$ & L & $\mathrm{H}$ & L & $\mathrm{H}$ \\
\hline Neutral detergent soluble fibre & L & $\mathrm{L}$ & $\mathrm{H}$ & $\mathrm{H}$ & $\mathrm{L}$ & $\mathrm{L}$ & $\mathrm{H}$ & $\mathrm{H}$ \\
\hline Crude protein & $\mathrm{H}$ & $\mathrm{H}$ & $\mathrm{H}$ & $\mathrm{H}$ & L & $\mathrm{L}$ & L & $\mathrm{L}$ \\
\hline \multicolumn{9}{|l|}{ Ingredients } \\
\hline Wheat grain & 180 & 90 & 90 & - & 180 & 90 & 90 & - \\
\hline Wheat bran & 40 & - & 40 & - & 40 & - & 40 & - \\
\hline Sunflower meal 28 & 360 & 355 & 360 & 355 & - & - & - & - \\
\hline Soybean protein concentrate 61 & - & - & - & - & 75 & 75 & 75 & 75 \\
\hline Fish meal 70 & 20 & 25 & 20 & 25 & 20 & 22.5 & 20 & 22.5 \\
\hline Beet pulp & 40 & 40 & 210 & 210 & 100 & 100 & 270 & 270 \\
\hline Oat hulls & 40 & 100 & 90 & 150 & 40 & 100 & 90 & 150 \\
\hline Defatted grape seed & 20 & 150 & 20 & 150 & 80 & 210 & 80 & 210 \\
\hline Grape pomace & 80 & 10 & 70 & - & 100 & 30 & 90 & 20 \\
\hline Soybean hulls & 40 & 40 & - & - & 40 & 40 & - & - \\
\hline Treated wheat straw & 80 & 80 & - & - & 210 & 207.5 & 130 & 127.5 \\
\hline Soybean oil & 50 & 50 & 50 & 50 & 50 & 50 & 50 & 50 \\
\hline Sugarcane molasses & 10 & 10 & 10 & 10 & 10 & 10 & 10 & 10 \\
\hline Corn starch & - & 10 & - & 10 & - & 10 & - & 10 \\
\hline L-Lysine $\mathrm{HCl}$ & 5 & 5 & 4.5 & 4.5 & 5.75 & 5.75 & 5 & 5 \\
\hline DL-Methionine & 1 & 1.25 & 1 & 1.25 & 4 & 4.25 & 4 & 4.25 \\
\hline L-Threonine & 1.5 & 1.75 & 1.25 & 1.5 & 3.5 & 3.75 & 3.25 & 3.5 \\
\hline L-Tryptophan & 1.5 & 1.5 & 1.5 & 1.5 & 2.25 & 2.25 & 2.25 & 2.25 \\
\hline Calcium carbonate & 12 & 8.5 & 11.25 & 7.75 & 3 & - & 3 & - \\
\hline Dicalcium phosphate & 10 & 13 & 11.5 & 14.5 & 27.5 & 30 & 28.5 & 31 \\
\hline Sodium chloride & 5 & 5 & 5 & 5 & 5 & 5 & 5 & 5 \\
\hline Vitamin/trace element premix ${ }^{2}$ & 4 & 4 & 4 & 4 & 4 & 4 & 4 & 4 \\
\hline
\end{tabular}

\footnotetext{
${ }^{1} \mathrm{~L}$, low; $\mathrm{H}$, high.

${ }^{2}$ Supplied per kg of feed: Vitamin A: $8.375 \mathrm{IU}$; Vitamin D3: $750 \mathrm{IU}$; Vitamin E: $20 \mathrm{mg}$; Vitamin $\mathrm{K}_{3}: 1 \mathrm{mg}$; Vitamin $B_{1}: 1 \mathrm{mg}$; Vitamin $B_{2}: 2$ mg; Vitamin $B_{6}: 1$ mg; Nicotinic acid: 20 mg; Choline chloride: 250 mg; Magnesium: 290 mg; Manganese: 20 mg; Zinc: 60 mg; lodine: 1.25 mg; Iron: 26 mg; Copper: 10 mg; Cobalt: $0.7 \mathrm{mg}$; Butyl hydroxylanysole and ethoxiquin mixture: $4 \mathrm{mg}$.
} 
Table 2. Chemical composition of the experimental diets ( $\mathrm{g} / \mathrm{kg}$ dry matter)

\begin{tabular}{|c|c|c|c|c|c|c|c|c|}
\hline Diets & LLH & $\mathrm{HLH}$ & $\mathrm{LHH}$ & $\mathrm{HHH}$ & LLL & HLL & $\mathrm{LHL}$ & $\mathrm{HHL}$ \\
\hline \multicolumn{9}{|l|}{ Nutrient level $^{1}$} \\
\hline Acid detergent fibre & $\mathrm{L}$ & $\mathrm{H}$ & $\mathrm{L}$ & $\mathrm{H}$ & $\mathrm{L}$ & $\mathrm{H}$ & $\mathrm{L}$ & $\mathrm{H}$ \\
\hline Neutral detergent soluble fibre & $\mathrm{L}$ & $\mathrm{L}$ & $\mathrm{H}$ & $\mathrm{H}$ & $\mathrm{L}$ & $\mathrm{L}$ & $\mathrm{H}$ & $\mathrm{H}$ \\
\hline Crude protein & $\mathrm{H}$ & $\mathrm{H}$ & $\mathrm{H}$ & $\mathrm{H}$ & $\mathrm{L}$ & $\mathrm{L}$ & $\mathrm{L}$ & $\mathrm{L}$ \\
\hline \multicolumn{9}{|l|}{ Chemical composition } \\
\hline Organic matter & 922 & 923 & 925 & 924 & 914 & 916 & 919 & 920 \\
\hline Crude protein & 174 & 176 & 175 & 174 & 147 & 147 & 145 & 144 \\
\hline Ether extract & 83 & 76 & 84 & 74 & 81 & 75 & 79 & 72 \\
\hline Starch & 130 & 83 & 79 & 31 & 129 & 83 & 85 & 28 \\
\hline Neutral detergent fibre, NDF & 412 & 480 & 424 & 497 & 407 & 464 & 423 & 486 \\
\hline Acid detergent fibre & 231 & 289 & 235 & 302 & 226 & 281 & 228 & 287 \\
\hline Acid detergent lignin, ADL & 59 & 97 & 61 & 104 & 54 & 93 & 55 & 93 \\
\hline ADL to NDF ratio & 0.14 & 0.20 & 0.14 & 0.21 & 0.13 & 0.20 & 0.13 & 0.19 \\
\hline Neutral detergent soluble fibre & 145 & 153 & 185 & 185 & 143 & 140 & 188 & 180 \\
\hline
\end{tabular}

${ }^{1} \mathrm{~L}$, low; $\mathrm{H}$, high.

Animals were housed in an experimental farm having a temperature within the range of $16^{\circ} \mathrm{C}$ to $24^{\circ} \mathrm{C}$ throughout the experimental period (AprilMay). Until weaning, litters were maintained in breeding cages $(50 \times 70 \times 32$ $\mathrm{cm}$ ) provided with nesting boxes; at weaning, litters were transferred to fattening cages $(50 \times 80 \times 32 \mathrm{~cm}, 8$ rabbits). Throughout the experiment, animals were fed ad libitum and had free access to water.

The experimental protocol followed both the Spanish Royal Decree 1201/2005 on protection of animals used for scientific purposes (Boletín Oficial del Estado, 2005) and the recommendations for applied nutrition research in rabbits described by the European Group on Rabbit Nutrition (Fernández-Carmona et al., 2005), being approved by the Committee of Ethics and Animal Welfare of the Universidad Politécnica de Valencia.

\section{Sampling of ileal and caecal contents}

After weighing, animals were slaughtered by intra-cardiac injection of sodium thiopental $(75 \mathrm{mg} / \mathrm{kg}$ live weight), between $20: 00$ and $23: 00 \mathrm{~h}$., to minimize the influence of caecotrophy on composition of digestive contents. Samples of ileal content were constituted by pooling digesta from distal part 
of the small intestine (around $30 \mathrm{~cm}$ before the ileo-caeco-colic valve) of 2-4 animals, to have quantity enough for analysing; samples were frozen at $-20^{\circ} \mathrm{C}$, freeze-dried and ground. Full caecal weight and $\mathrm{pH}$ of caecal digesta were recorded; around $1 \mathrm{~g}$ of caecal digesta was added with $2 \mathrm{~mL}$ of $0.35 \mathrm{M} \mathrm{H}_{3} \mathrm{PO}_{4}$ or with $3 \mathrm{~mL}$ of $0.35 \mathrm{M} \mathrm{H}_{2} \mathrm{SO}_{4}$, to determine volatile fatty acid (VFA) and ammonia concentrations, respectively; the rest of caecal content was used to determine its DM content. All the caecal digesta samples were frozen at $-20^{\circ} \mathrm{C}$ until analysis. Samples from animals showing signs of digestive troubles (abnormal caecal or colic contents, dirty perineum) were discarded.

\section{Chemical analyses}

Analyses of DM, ash, CP and ether extract were performed according to methods of the AOAC (2000) (934.01, 942.05, 976.06 and 920.39, respectively); previous acid-hydrolysis of samples was done in the analysis of ether extract.

Starch was analysed according to Batey (1982), by a two-step enzymatic procedure with solubilisation and hydrolysis to maltodextrins with thermostable $\alpha$-amylase followed by complete hydrolysis with amyloglucosidase (both enzymes from Sigma-Aldrich, Steinheim, Germany), and the resulting glucose being measured by the hexokinase/glucose- 6 phosphate dehydrogenase/NADP system (R-Biopharm, Darmstadt, Germany). Neutral detergent fibre (NDF), ADF and acid detergent lignin (ADL) were analysed sequentially (Van Soest et al., 1991) using a thermo-stable amylase (Thermamyl L120, Novo Nordisk, Gentofte, Denmark) and expressed exclusive of residual ash, using a nylon filter bag system (Ankom, Macedon, NY, USA). NDSF content was determined according to Hall et al. (1997), adapting the method to the nylon filter bag system and with the following modifications: a Soxhlet extraction of samples with petroleum ether ( 6 hours) was performed prior to the ethanol-water extraction and the neutral detergent extraction was done on the ether-ethanol insoluble residue instead of on the raw sample.

Ytterbium was analysed according to García et al. (1999), by atomic absorption spectrometry (Smith-Hieftje 22, Thermo Jarrell Ash, MA, USA) using 
pre-dosed samples of faeces to prepare common-matrix standards; samples were previously ashed $\left(550^{\circ} \mathrm{C}\right)$ and digested by boiling with a solution of $1.5 \mathrm{M}$ $\mathrm{HNO}_{3}$ and $0.05 \mathrm{M} \mathrm{KCl}$.

For VFA analysis, samples were previously filtered through a cellulose filter (0.45) and $250 \mu \mathrm{L}$ were transferred to the injection vials; $2 \mu \mathrm{L}$ from each sample were injected into the gas chromatograph (Fisons 8000 series, Milan, Italy) equipped with an AS800 automatic injector; the column used was a BDFFAP $30 \mathrm{~mm} \times 0.25 \mathrm{~mm} \times 0.25 \mathrm{~mm}$; injector and detector temperatures were maintained at 220 and $225{ }^{\circ} \mathrm{C}$, respectively. Ammonia concentration was determined according to procedure 984.13 of the AOAC (2000). Both VFA and ammonia concentrations were expressed as $\mathrm{mmol} / \mathrm{L}$ of liquid phase of caecal content, after correcting by the dilution factor calculated from the water content of sample and the added volume of $\mathrm{H}_{3} \mathrm{PO}_{4}$ or $\mathrm{H}_{2} \mathrm{SO}_{4}$ solutions.

\section{Statistical analysis}

Data were analysed using the GLM procedure of SAS (Statistical Analysis Systems Institute, 2002). The model included the main effect of the diet (LLH, $\mathrm{HLH}, \mathrm{LHH}, \mathrm{HHH}, \mathrm{LLL}, \mathrm{HLL}, \mathrm{LHL}$ and HHL) and the litter (nested to diet) and the error term as random effects. Orthogonal contrasts were computed to test differences due to replacement of starch with ADF $[(\mathrm{HLH}+\mathrm{HHH}+\mathrm{HLL}+\mathrm{HHL}) / 4$ $-(\mathrm{LLH}+\mathrm{LHH}+\mathrm{LLL}+\mathrm{LHL}) / 4]$, to replacement of starch with NDSF $[(\mathrm{LHH}+\mathrm{HHH}+\mathrm{LHL}+\mathrm{HHL}) / 4-(\mathrm{LLH}+\mathrm{HLH}+\mathrm{LLL}+\mathrm{HLL}) / 4]$ and to $\mathrm{CP}$ reduction $[(\mathrm{LLL}+\mathrm{HLL}+\mathrm{LHL}+\mathrm{HHL}) / 4-(\mathrm{LLH}+\mathrm{HLH}+\mathrm{LHH}+\mathrm{HHH}) / 4]$.

Additional contrasts were performed to look for interactions between the three dietary factors: i) ADF and NDSF levels (ADF increase in low NDSF $[(\mathrm{HLH}+\mathrm{HLL}) / 2-(\mathrm{LLH}+\mathrm{LLL}) / 2]$ or high NDSF diets $[(\mathrm{HHH}+\mathrm{HHL}) / 2-\mathrm{LHH}+\mathrm{LHL}) / 2])$, ii) ADF and CP levels (ADF increase in high CP $[(\mathrm{HLH}+\mathrm{HHH}) / 2-(\mathrm{LLH}+\mathrm{LHH} / 2]$ or low $C P$ diets $[(H L L+H H L) / 2-(L L L+L H L) / 2])$ and iii) NDSF and CP levels (NDSF increase in high $\mathrm{CP}[(\mathrm{LHH}+\mathrm{HHH}) / 2-(\mathrm{LLH}+\mathrm{HLH} / 2]$ or low $\mathrm{CP}$ diets $[(\mathrm{LHL}+\mathrm{HHL}) / 2-(\mathrm{LLL}+\mathrm{HLL}) / 2])$. 


\section{Results}

Ileal apparent digestibility

Table 3 shows the coefficients of ileal apparent digestibility (CIAD) of DM, $C P$, starch and NDSF obtained for the experimental diets. The CIAD of starch was not affected by the dietary changes (averaging $0.946 \pm 0.004$ ). The substitution of ADF for starch reduced CIAD of DM (0.292 vs. $0.229, P<0.01)$, with no effect on CIAD of both CP and NDSF. The substitution of NDSF for starch reduced CIAD of DM in less extent (0.277 vs. 0.244, $P=0.09$ ); in this case, CIAD of CP was also reduced (0.574 vs. 0.529, $P=0.07$ ) while CIAD of NDSF increased $(-0.040$ vs. 0.099, $P<0.01)$. On the other hand, the reduction of $C P$ content led to lower CIAD of DM (0.277 vs. $0.244, P=0.09), C P(0.578$ vs. 0.525, $P<0.05)$ and NDSF (0.086 vs. $-0.038, P<0.01)$.

\section{Caecal traits}

Table 4 shows the dietary effect on weight of caecum (relative to live weight) and on major parameters describing caecal environment.

The effects of substitution of ADF or NDSF for starch and of its interaction on caecal weight, as well as on DM content and $\mathrm{pH}$ of caecal digesta, are illustrated in Figure 1. Thus, ADF replacing starch reduced caecal weight only in animals fed high NDSF diets $(-0.009 \pm 0.003, P<0.01)$ while NDSF replacing starch increased this trait, more extensively with low ADF diets $(+0.015 \pm 0.003, P<0.001)$ than with high ADF diets $(+0.009 \pm 0.003, P<0.01)$. DM content of caecal digesta increased when ADF replaced starch, in greater extent with high NDSF diets $(+31 \pm 4 \mathrm{~g} / \mathrm{kg}, P<0.001)$ than with low NDSF diets $(+16 \pm 4 \mathrm{~g} / \mathrm{kg}, P<0.001)$, while NDSF replacing starch reduced this trait only with low ADF diets $(-16 \pm 5 \mathrm{~g} / \mathrm{kg}, P<0.001)$. The effect of ADF replacing starch was not significant for $\mathrm{pH}$ because it led to an increase in low NDSF diets $(+0.08 \pm 0.04, P<0.05)$ and to a decrease in high NDSF diets $(-0.10 \pm 0.04$, $P<0.05)$, while NDSF replacing starch reduced this trait only with high ADF diets $(-0.14 \pm 0.04, P<0.001)$. 
Table 3. Effect of the experimental diets on the coefficients of ileal apparent digestibility of dry matter, crude protein, starch and neutral detergent soluble fibre in 35 day-old rabbits

\begin{tabular}{|c|c|c|c|c|c|c|c|c|c|c|c|c|}
\hline & \multicolumn{8}{|c|}{ Diet $^{1}$} & \multicolumn{4}{|c|}{ Contrast $^{2}$} \\
\hline & LLH & $\mathrm{HLH}$ & $\mathrm{LHH}$ & $\mathrm{HHH}$ & LLL & HLL & $\mathrm{LHL}$ & $\mathrm{HHL}$ & $\begin{array}{c}\text { ADF } \\
\text { for starch }\end{array}$ & $\begin{array}{c}\text { NDSF } \\
\text { for starch }\end{array}$ & $\begin{array}{c}\mathrm{CP} \\
\text { reduction }\end{array}$ & SED $^{3}$ \\
\hline Number of observations & 8 & 8 & 8 & 8 & 8 & 8 & 8 & 8 & & & & \\
\hline Dry matter & $0.314^{a}$ & $0.258^{\mathrm{abc}}$ & $0.293^{\mathrm{ab}}$ & $0.244^{\mathrm{abc}}$ & $0.316^{a}$ & $0.221^{b c}$ & $0.245^{\mathrm{abc}}$ & $0.193^{c}$ & $-0.063^{* *}$ & $-0.033^{\dagger}$ & $-0.034^{\dagger}$ & 0.019 \\
\hline Crude protein & $0.613^{a}$ & $0.569^{a b c}$ & $0.574^{\mathrm{abc}}$ & $0.557^{\mathrm{abc}}$ & $0.601^{\mathrm{ab}}$ & $0.512^{\mathrm{cd}}$ & $0.463^{d}$ & $0.524^{b c d}$ & -0.022 & $-0.044^{\dagger}$ & $-0.053^{*}$ & 0.023 \\
\hline Starch & $0.936^{\mathrm{ab}}$ & $0.921^{b}$ & $0.945^{\mathrm{ab}}$ & $0.970^{a}$ & $0.957^{a}$ & $0.953^{a b}$ & $0.934^{\mathrm{ab}}$ & $0.952^{\mathrm{ab}}$ & 0.006 & 0.009 & 0.006 & 0.008 \\
\hline Neutral detergent soluble fibre & $0.043^{a b c}$ & $0.048^{a b}$ & $0.133^{a}$ & $0.121^{a b}$ & $-0.092^{c}$ & $-0.157^{c}$ & $0.096^{\mathrm{ab}}$ & $0.002^{b c}$ & -0.042 & $0.127^{* *}$ & $-0.124^{* *}$ & 0.036 \\
\hline
\end{tabular}

${ }^{1}$ First, second and third letters show acid detergent fibre (ADF), neutral detergent soluble fibre (NDSF) and crude protein (CP) levels (low, $\mathrm{L}$; high, $\mathrm{H}$ ), respectively.

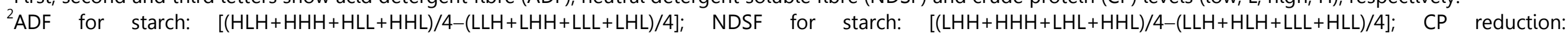
$[(\mathrm{LLL}+\mathrm{HLL}+\mathrm{LHL}+\mathrm{HHL}) / 4-(\mathrm{LLH}+\mathrm{HLH}+\mathrm{LHH}+\mathrm{HHH}) / 4]$.

${ }^{3}$ Standard error of difference.

$+P<0.1 ; * P<0.05 ; * * P<0.01 ; * * * P<0.001$

$a, b, c, d$ Within a row, means not sharing any common superscript are significantly different $(P<0.05)$ 
Table 4. Effect of the experimental diets on caecal traits in 35 day-old rabbits

\begin{tabular}{|c|c|c|c|c|c|c|c|c|c|c|c|c|}
\hline & \multicolumn{8}{|c|}{ Diet $^{1}$} & \multicolumn{4}{|c|}{ Contrast $^{2}$} \\
\hline & LLH & $\mathrm{HLH}$ & $\mathrm{LHH}$ & $\mathrm{HHH}$ & LLL & HLL & LHL & $\mathrm{HHL}$ & $\begin{array}{c}\text { ADF } \\
\text { for starch }\end{array}$ & $\begin{array}{c}\text { NDSF } \\
\text { for starch }\end{array}$ & $\begin{array}{c}\mathrm{CP} \\
\text { reduction }\end{array}$ & $\mathrm{SED}^{3}$ \\
\hline Number of observations & 18 & 18 & 21 & 28 & 29 & 27 & 21 & 25 & & & & \\
\hline Caecal weight $^{4}$ & $0.082^{a b}$ & $0.074^{\mathrm{b}}$ & $0.099^{\mathrm{a}}$ & $0.091^{\mathrm{ab}}$ & $0.082^{\mathrm{ab}}$ & $0.085^{\mathrm{ab}}$ & $0.095^{\mathrm{a}}$ & $0.086^{\mathrm{ab}}$ & $-0.006^{\star *}$ & $0.012^{\star \star *}$ & 0.001 & 0.002 \\
\hline $\mathrm{pH}$ & $5.88^{\mathrm{abc}}$ & $5.91^{\mathrm{abc}}$ & $5.90^{\mathrm{abc}}$ & $5.80^{c}$ & $5.89^{\mathrm{abc}}$ & $6.03^{\mathrm{a}}$ & $5.95^{\mathrm{ab}}$ & $5.86^{\mathrm{bc}}$ & -0.01 & $-0.05^{\dagger}$ & $0.06^{*}$ & 0.03 \\
\hline Dry matter $(\mathrm{g} / \mathrm{kg})$ & $228^{\mathrm{abc}}$ & $246^{\mathrm{a}}$ & $205^{c}$ & $238^{\mathrm{a}}$ & $218^{b c}$ & $231^{\mathrm{ab}}$ & $208^{c}$ & $237^{\mathrm{a}}$ & $24^{* * *}$ & $-9^{* *}$ & $-6^{\dagger}$ & 3 \\
\hline Total VFA ${ }^{5}(\mathrm{mmol} / \mathrm{L})$ & $71.8^{\mathrm{abc}}$ & $74.8^{\mathrm{abc}}$ & $79.8^{\mathrm{abc}}$ & $84.5^{\mathrm{a}}$ & $58.7^{c}$ & $64.4^{\mathrm{bc}}$ & $62.5^{\mathrm{bc}}$ & $80.5^{\mathrm{ab}}$ & $7.9^{* *}$ & $9.4^{* *}$ & $-11.2^{\star \star \star}$ & 3.0 \\
\hline Acetate (molar proportion) & $0.836^{\mathrm{a}}$ & $0.847^{\mathrm{a}}$ & $0.816^{\mathrm{a}}$ & $0.821^{\mathrm{a}}$ & $0.844^{\mathrm{a}}$ & $0.836^{\mathrm{a}}$ & $0.827^{\mathrm{a}}$ & $0.818^{\mathrm{a}}$ & -0.001 & $-0.021^{\star x \star}$ & 0.001 & 0.005 \\
\hline Propionate (molar proportion) & $0.052^{\mathrm{a}}$ & $0.049^{\mathrm{a}}$ & $0.057^{\mathrm{a}}$ & $0.056^{\mathrm{a}}$ & $0.046^{\mathrm{a}}$ & $0.057^{\mathrm{a}}$ & $0.050^{\mathrm{a}}$ & $0.053^{\mathrm{a}}$ & 0.003 & 0.003 & -0.002 & 0.002 \\
\hline Butyrate (molar proportion) & $0.099^{\mathrm{a}}$ & $0.093^{\mathrm{a}}$ & $0.108^{\mathrm{a}}$ & $0.113^{\mathrm{a}}$ & $0.094^{\mathrm{a}}$ & $0.095^{\mathrm{a}}$ & $0.108^{\mathrm{a}}$ & $0.117^{\mathrm{a}}$ & 0.002 & $0.016^{*}$ & 0.000 & 0.004 \\
\hline Ammonia (mmol/L) & $16.0^{\mathrm{ab}}$ & $17.2^{\mathrm{a}}$ & $15.1^{\mathrm{abc}}$ & $14.8^{\mathrm{abc}}$ & $12.5^{\mathrm{bc}}$ & $12.4^{\mathrm{bc}}$ & $11.1^{\mathrm{c}}$ & $12.3^{\mathrm{bc}}$ & 0.5 & $-1.2^{*}$ & $-3.7^{\star * *}$ & 0.6 \\
\hline
\end{tabular}

${ }^{1}$ First, second and third letters show acid detergent fibre (ADF), neutral detergent soluble fibre (NDSF) and crude protein (CP) levels (low, $\mathrm{L}$; high, $\left.\mathrm{H}\right)$, respectively.

${ }^{2} \mathrm{ADF}$ for starch: $[(\mathrm{HLH}+\mathrm{HHH}+\mathrm{HLL}+\mathrm{HHL}) / 4-(\mathrm{LLH}+\mathrm{LHH}+\mathrm{LLL}+\mathrm{LHL}) / 4] ; \quad \mathrm{NDSF}$ for starch: $[(\mathrm{LHH}+\mathrm{HHH}+\mathrm{LHL}+\mathrm{HHL}) / 4-(\mathrm{LLH}+\mathrm{HLH}+\mathrm{LLL}+\mathrm{HLL}) / 4] ; \quad \mathrm{CP} \quad$ reduction: $[(\mathrm{LLL}+\mathrm{HLL}+\mathrm{LHL}+\mathrm{HHL}) / 4-(\mathrm{LLH}+\mathrm{HLH}+\mathrm{LHH}+\mathrm{HHH}) / 4]$.

${ }^{3}$ Standard error of difference.

${ }^{4}$ Expressed as a proportion of live weight.

${ }^{5}$ Volatile fatty acids.

$+P<0.1 ;{ }^{*} P<0.05 ;{ }^{* *} P<0.01 ; * * * P<0.001$

$\mathrm{a}, \mathrm{b}, \mathrm{c}$, Within a row, means not sharing any common superscript are significantly different $(P<0.05)$ 

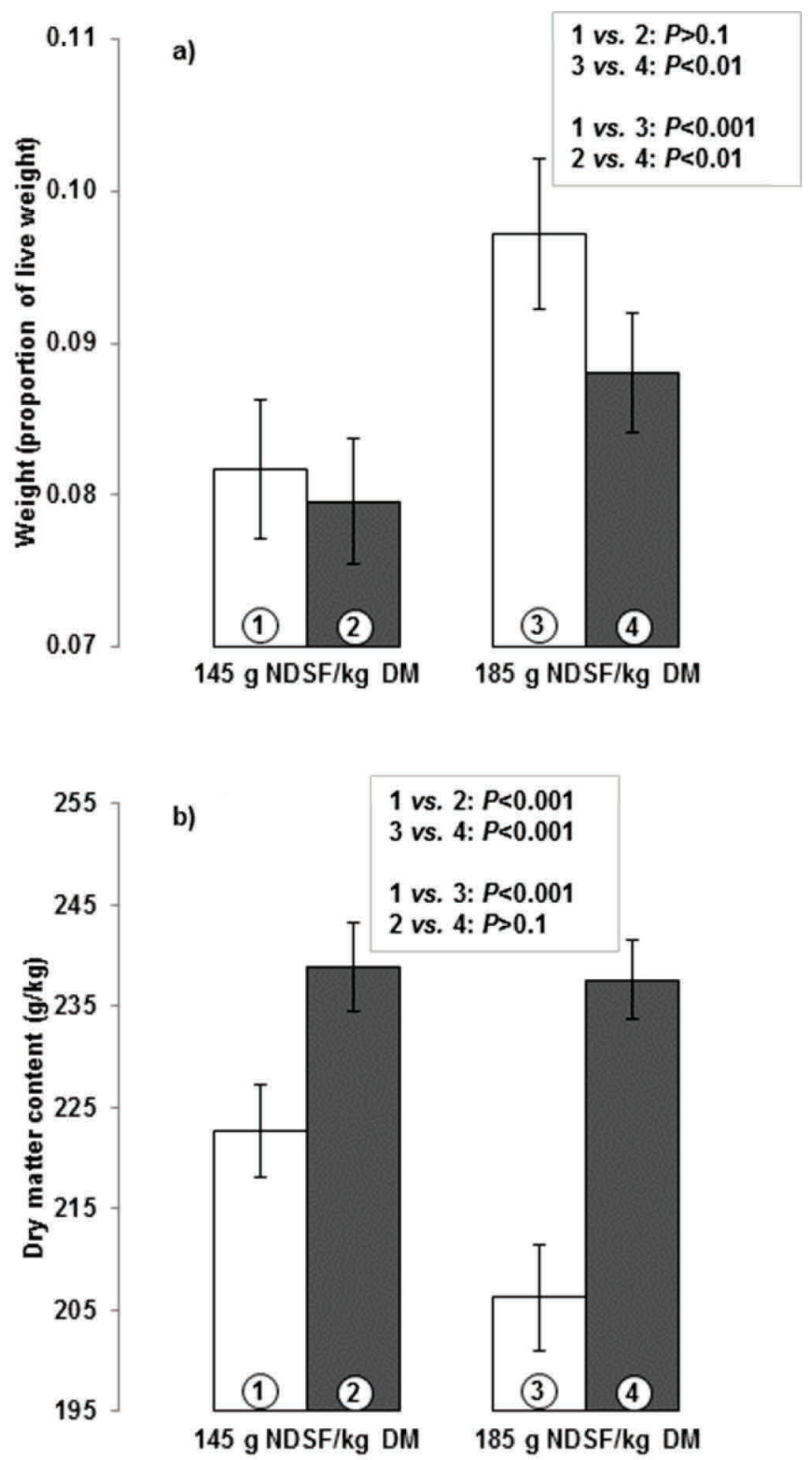

1 vs. $2: P<0.001$

3 vs. $4: P<0.001$

1 vs. 3: $P<0.001$

2 vs. $4: P>0.1$
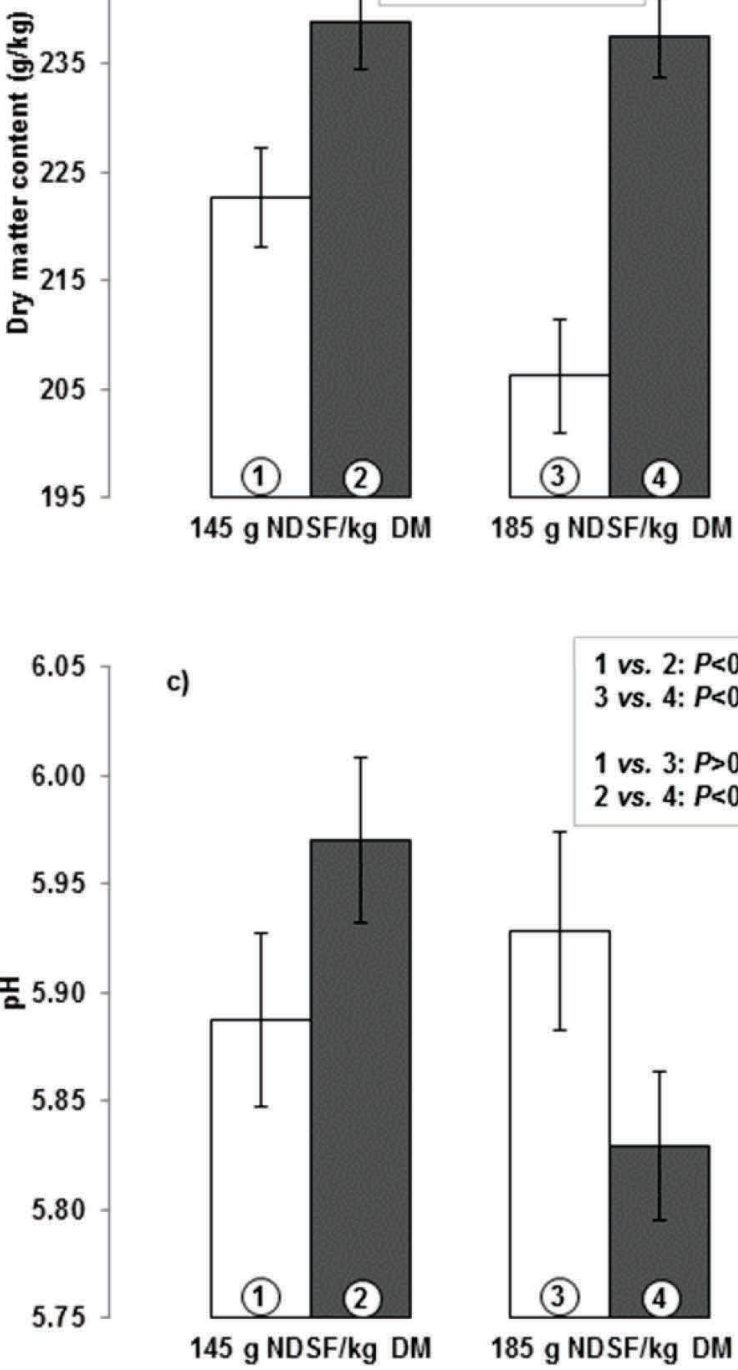

3 vs. $4: P<0.05$

1 vs. $3: P>0.1$

2 vs. $4: P<0.001$

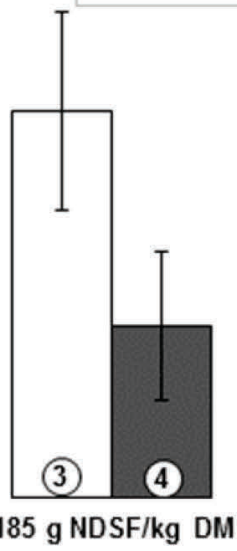

Figure 1. Interaction between acid detergent fibre (ADF) and neutral detergent soluble fibre (NDSF) levels on caecal weight (a), dry matter content (b) and $\mathrm{pH}$ (c). 1: low ADF-low NDSF (LLH and LLL); 2: high ADF-low NDSF (HLH and HLL); 3: low ADF-high NDSF (LHH and LHL); 4: high ADF-high NDSF ( $\mathrm{HHH}$ and $\mathrm{HHL}$ ). 
Both ADF and NDSF replacing starch increased total VFA concentration of caecal digesta $(+11.5 \%$ and $+13.9 \%$, respectively, $P<0.01)$, but molar proportions of the main VFA were only affected by the replacement with NDSF, which led to an increase of butyrate $(0.095 \mathrm{vs} .0 .112, P<0.001)$ at the expense of mainly acetate $(0.841 \mathrm{vs} .0 .820, P<0.001)$. Ammonia concentration was not affected by ADF replacing starch while replacement with NDSF led to a reduction in this trait $(-8.1 \%, P<0.05)$.

The $\mathrm{CP}$ reduction did not affect caecal weight and decreased $\mathrm{DM}$ content of caecal digesta only with low NDSF diets $(-12 \pm 4 \mathrm{~g} / \mathrm{kg}, P<0.01)$ but not with high NDSF diets $(+1 \pm 4 \mathrm{~g} / \mathrm{kg}, P>0.1)$. This dietary change increased caecal $\mathrm{pH}$ (5.87 vs. 5.93, $P<0.05)$, reduced total VFA concentration of caecal digesta $(-14.4 \%, P<0.001)$ and led to lower ammonia concentration $(-23.5 \%, P<0.001)$.

\section{Discussion}

\section{Replacement of starch with fibre}

The major variations observed in CIAD of DM between the experimental diets reveal differences in their carbohydrate composition. Thus, the replacement of starch with ADF impaired CIAD of DM in the expected extent, since CIAD of starch was always very high (0.92-0.97), in accordance with usual values in growing rabbits (Blas and Gidenne, 2010), whereas low pre-caecal digestion of ADF can be assumed. CIAD of ADF of 0.13-0.18 and 0.08-0.18 have been reported by Soler et al. (2006) and Gidenne et al. (2000) in growing and adult rabbits, respectively; studies in adult rabbits have reported CIAD of non-starch glucose (mainly from cellulose) being close to zero (Gidenne, 1992; Carabaño et al., 2001).

On the other hand, the impairment of CIAD of DM (close to statistical significance) when NDSF replaced starch would be related to low CIAD of this fibrous fraction. No data on pre-caecal digestibility of NDSF in growing or adult rabbits are found in the literature. In spite of its very high residual variability (mean: 0.010, residual standard deviation: 0.102), a significant 
increase in CIAD of NDSF was detected as a result of increasing NDSF content, probably because of higher contribution of beet pulp to this fraction (from 0.14 to 0.58 in high CP diets, from 0.36 to 0.75 in low CP diets). Beet pulp is rich in pectic substances and high CIAD (0.2-0.5) of their main constituent monomers (uronic acids, arabinose) has been reported in adult rabbits (Gidenne, 1992; Carabaño et al., 2001), as a consequence of microbial enzyme activity in stomach and small intestine from microbiota supplied by soft faeces (Marounek et al., 1995). Moreover, the inclusion of beet pulp in rabbit diets has been associated to increased intestinal viscosity (Volek et al., 2005) and to a reduction in CIAD of CP because of greater endogenous losses (Chamorro et al., 2007); these facts could explain the impairment in CIAD of CP detected with high NDSF diets in the current study.

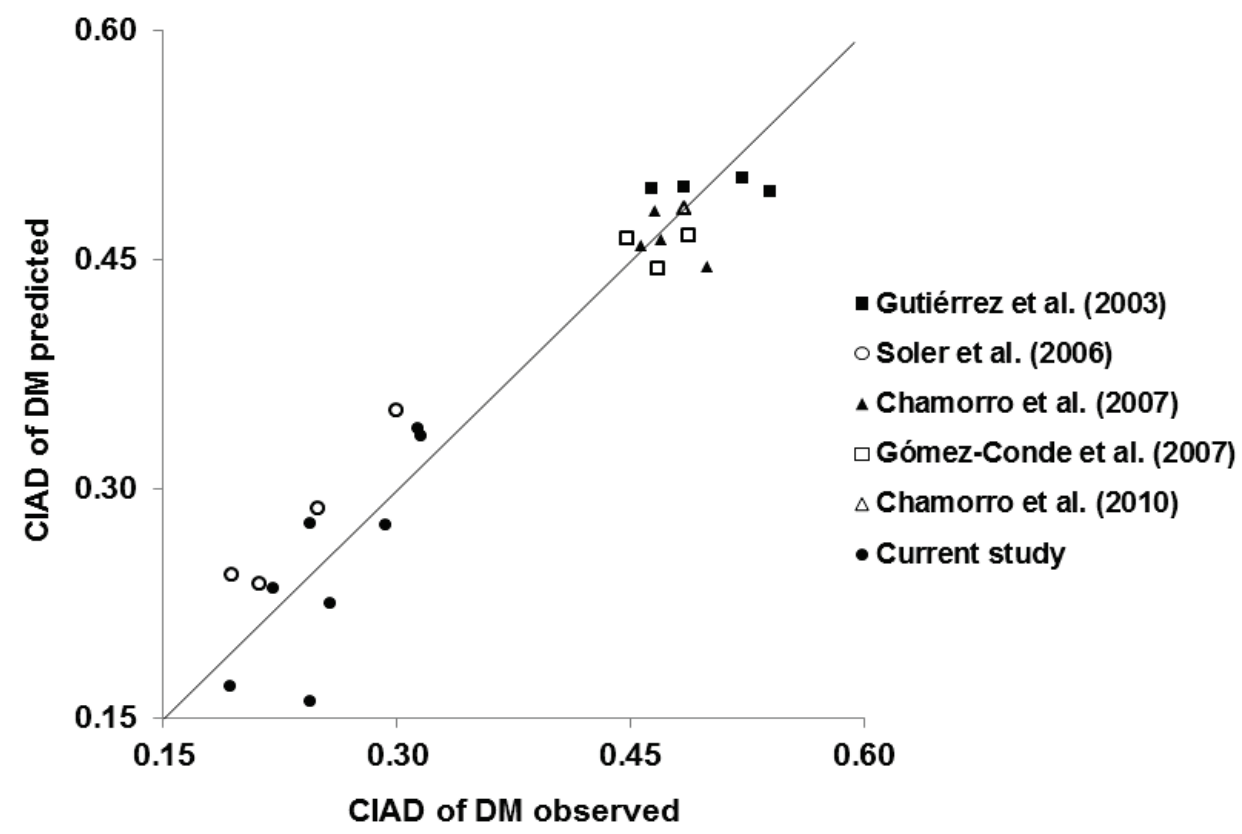

Figure 2. Predicted values for coefficient of ileal apparent digestibility of dry matter (CIAD of DM) according to the equation: CIAD of DM $=0.604( \pm 0.164, P<0.01)+$ $0.000892( \pm 0.000235, P<0.01) \times \operatorname{starch}(\mathrm{g} / \mathrm{kg} \mathrm{DM})-0.000972( \pm 0.000336, P<0.01) \times$ $\mathrm{NDF}(\mathrm{g} / \mathrm{kg} D M), R S D=0.035, \mathrm{R}^{2}=0.92, \mathrm{n}=24$.

Values obtained for CIAD of DM in the current study were comparable to those reported by Soler et al. (2006) with similar diets but clearly lower than those usually recorded using diets more concentrated, with 200-245 g starch 
and 325-365 g NDF/kg DM (Gutiérrez et al., 2003; Chamorro et al., 2007 and 2010; Gómez-Conde et al., 2007), supporting the major effect of carbohydrate composition on ileal digestibility of DM above mentioned. The multiple linear regression equation presented in Figure 2 illustrates this fact.

The dietary factors affecting caecal traits have been reviewed by García et al. (2002) in a meta-study with data from diets used in different experiments, attributing the main role to the level and type of fibre. Thus, caecal weight depends quadratically on the dietary NDF content (being minimal with $393 \mathrm{~g}$ NDF/kg DM) and decreases linearly with the increase of both the degree of lignification of NDF and the feed intake. On the other hand, it has been frequently reported that diets rich in pectins, usually from beet pulp, led to higher caecal weight (Candau et al., 1978; Fraga et al., 1991; García et al., 1993; Carabaño et al., 1997; Gidenne and Bellier, 2000; Falcão-e-Cunha et al., 2004), regardless of simultaneous wide variations in the level of insoluble fibre (NDF, ADF, lignin) and/or starch. Gómez-Conde et al. (2009) also found higher caecal weight as a consequence of increasing NDSF in iso-ADF (165 g/ $/ \mathrm{kg} \mathrm{DM})$ and iso-starch (208 $\mathrm{g} / \mathrm{kg} \mathrm{DM}$ ) diets. The current study confirms that caecal weight is affected by the interaction between level and type of dietary fibre. Thus, the increase in ADF from 230 to $290 \mathrm{~g} / \mathrm{kg}$ DM (and concomitantly in NDF from 417 to $482 \mathrm{~g} / \mathrm{kg} \mathrm{DM}$, in ADL from 57 to $97 / \mathrm{kg} \mathrm{DM}$ and in ADL to NDF ratio from 0.14 to 0.20$)$ reduced caecal weight in animals fed high NDSF diets $(185 \mathrm{~g} / \mathrm{kg}$ DM), whereas had no effect in those fed low NDSF diets (145 g/ $\mathrm{kg} \mathrm{DM);} \mathrm{as}$ caecal weight is an indirect measurement of ileo-rectal rate of passage (Gidenne et al., 2010a), the lack of effect in low NDSF diets could be explained by their ADF content being already high enough to maximize this rate of passage; similarly, Trocino et al. (2010) found no variation in caecal weight when using diets differing in soluble fibre content and having $215 \mathrm{~g} \mathrm{ADF} / \mathrm{kg}$ DM (and $90 \mathrm{~g}$ starch $/ \mathrm{kg} \mathrm{DM}$ ). Therefore, the effect of insoluble fibre in reducing caecal weight would also persist above the limit proposed by García et al. (2002) if diets are rich in pectins, in such a way that the effect of pectins increasing caecal weight is softened by very high insoluble fibre levels. In a 
previous study using the same diets (Martínez-Vallespín et al., 2011), the increase of ADF induced higher feed intake in 4-7 week-old rabbits whatever the level of NDSF; similarly, ileal flow of DM (calculated by using feed intake from that work) would be higher when increasing ADF (75 vs. $92 \mathrm{~g} /$ day). Consequently, ADF stimulating caecal rate of passage in greater extent with high than with low NDSF diets can be hypothesized to explain our results.

Furthermore, the above mentioned interaction between level and type of fibre affected DM content of caecal digesta. The increase of DM content with ADF could be a consequence of higher ileal flow of DM; in the high NDSF diets, the increase of DM content was larger, which could be explained by an additional effect of a differentiated transit, faster for liquid than for solid phase, associated to stimulated caecal rate of passage. In this way, faster ororectal rate of passage of fine particles and not of large ones has been reported when increasing the dietary lignin content (Gidenne and Perez, 1994); similarly, Gidenne and Perez (2000) and Gidenne and Jehl (1996) found faster oro-rectal rate of passage of liquid phase and fine particles (and not of large ones) or faster ileo-rectal rate of passage of liquid phase (and not of solid one), respectively, when increasing the dietary fibre level (cellulose+insoluble hemicelluloses+pectins). On the other hand, the increase of NDSF induced lower DM content in low ADF diets probably because of higher water retention capacity of the constituents of soluble fibre, as mainly pectins (Gidenne et al., 2010a); however, no differences were found in high ADF diets because this effect could have been compensated by the referred differentiated transit of liquid and solid phases.

According the meta-study of García et al. (2002), VFA concentration of caecal digesta increases with the dietary content in uronic acids (the monomers constituting the backbone of pectins, which are the non-starch polysaccharides more fermentables) and NDF, whereas is negatively affected by the degree of lignification of NDF. Likewise, higher VFA concentration has been observed when several fibrous constituents (pectins, insoluble hemicelluloses, cellulose) increase simultaneously at the expense of starch 
(Jehl and Gidenne, 1996; Gidenne and Bellier, 2000). Some recent studies (Trocino et al., 2011; Xiccato et al., 2011) also found higher VFA concentration when soluble fibre replaced starch. Coherently, in the current study, VFA concentration of caecal digesta increased in high NDSF or ADF diets (the latter being also high in NDF, although with higher degree of lignification); in this way, maximum VFA concentration was observed when NDSF and ADF increased concurrently at the expense of starch. Nevertheless, the difference in fermentative activity depending on the NDSF level cannot be supported by the difference in the calculated ileal flow of this fibrous fraction (17.5 and 18.2 g/day for low and high NDSF diets, respectively), which would show important methodological limitations in determining that flow.

Regarding to the VFA profile, García et al. (2002) found that acetate increased and butyrate decreased when increasing NDF whereas propionate was positively correlated with the uronic acid content; the same effect on acetate and butyrate molar proportions has been reported by Xiccato et al. (2011) when increasing soluble fibre content. On the contrary, in the current work, no effect of ADF replacing starch was found on VFA profile whereas NDSF replacing starch consistently reduced the contribution of acetate and increased that of butyrate.

Ammonia concentration in caecal digesta was reduced as a result of NDSF replacing starch, which could be explained by enhanced microbial activity and subsequent increase of ammonia uptake for microbial protein synthesis, since the calculated ileal flow of $\mathrm{CP}$ was very similar in low than in high NDSF diets (8.0 vs. $8.1 \mathrm{~g}$ /day). Xiccato et al. (2011) also reported lower ammonia concentration as a consequence of a large increase of soluble fibre at the expense of starch; Trocino et al. (2011) found no effect when this replacement was slighter. On the other hand, enhanced microbial activity when ADF replaced starch was not reflected in reduction of ammonia concentration because higher ammonia uptake by microbiota could be compensated by an increase in ammonia production as a result of enhanced 
proteolytic activity; in fact, the calculated ileal flow of CP increased with high ADF diets (7.3 vs. $8.7 \mathrm{~g} /$ day).

It has been indicated that uronic acids are the only dietary constituent explaining a relevant part (0.67) of the variation observed in caecal $\mathrm{pH}$, which depends not only on VFA and ammonia concentration in caecal digesta (both explaining only $12 \%$ of caecal $\mathrm{pH}$ variability) but also on other factors related with physicochemical characteristics of caecal DM (García et al., 2002). In the current study, a stepwise multiple linear regression analysis to examine the relationship between caecal $\mathrm{pH}$ and other caecal traits revealed VFA concentration as the only variable retained in the model $[\mathrm{pH}=6.31( \pm 0.03$, $P<0.001)-0.0058( \pm 0.0004, P<0.001) \times$ VFA $(\mathrm{mmol} / \mathrm{L}), \mathrm{RSD}=0.13, \mathrm{R}^{2}=0.51$, $\mathrm{n}=187]$; in this line, as observed in Figure 1, minimum $\mathrm{pH}$ value was recorded with diets which NDSF and ADF contents increased concurrently at the expense of starch and in which VFA concentration was maximum.

\section{Reduction of CP content}

The reduction of CP content from 175 to $145 \mathrm{~g} / \mathrm{kg}$ impaired CIAD of this fraction. The contribution of fibrous raw materials (beet pulp, oat hulls, defatted grape seed, grape pomace, soybean hulls and treated wheat straw) to $C P$ supply was larger in low than in high CP diets (0.37 vs. 0.19$)$ and lower CIAD of CP has been reported for fibrous raw materials than for concentrates (Carabaño et al., 2009); higher proportion of ileal endogenous nitrogen in low $\mathrm{CP}$ diets should be also taken into account. The $\mathrm{CP}$ reduction also led to an impairment of CIAD of NDSF, in spite of higher contribution of beet pulp to this fraction in low than in high $\mathrm{CP}$ diets $(0.55$ vs. 0.36); lower pre-caecal microbial activity because of insufficient $\mathrm{N}$ availability could be hypothesized; in fact, as commented below, caecal microbial activity seemed to be depressed when reducing the $\mathrm{CP}$ content. It is remarkable that the combined effect of CP reduction on CIAD of both CP and NDSF would explain a major part of the impairment of CIAD of DM as a result of this dietary change. 
In the current study, the reduction of dietary CP content from 175 to 145 $\mathrm{g} / \mathrm{kg}$ DM led to a fall of VFA concentration in caecal digesta, which indicates lower microbial activity; similarly, Xiccato et al. (2011) also found lower VFA concentration when reducing CP content from 182 to $169 \mathrm{~g} / \mathrm{kg} \mathrm{DM}$. Calculated ileal flow of CP was lower as a consequence of this dietary change (8.5 vs. 7.5 $\mathrm{g} /$ day) and $\mathrm{N}$ availability could have become limiting for microbial activity. In fact, lower ammonia concentration was recorded with low CP diets (12.1 $\mathrm{mmol} / \mathrm{L}$ ); however, this value is in the upper part of the range reported in the literature and Villamide et al. (2010) point out that an ammonia concentration of $4.5-6 \mathrm{mmol} / \mathrm{L}$ seems adequate for appropriate protein microbial synthesis.

\section{Conclusion}

The partial replacement of starch with ADF or with NDSF or the reduction of CP content from 175 to $145 \mathrm{~g} / \mathrm{kg}$ DM in diets for young rabbits around weaning led to changes in caecal environment which can be considered as favourable for digestive health. In this way, a stepwise multiple linear regression analysis to examine the relationship between the mortality rate reported in a context of Epizootic Rabbit Enteropathy in 4-7 week-old rabbits fed the diets used in the current study (Martínez-Vallespín et al., 2011) and the caecal traits resulted in the following equation: Mortality rate $=0.595( \pm 0.164$, $P<0.05)-0.00270( \pm 0.00080, P<0.05) \times \mathrm{DM}(\mathrm{g} / \mathrm{kg})-0.00821( \pm 0.00135$, $P<0.01) \times$ VFA $(\mathrm{mmol} / \mathrm{L})+0.0803( \pm 0.0060, P<0.001) \times$ Ammonia $(\mathrm{mmol} / \mathrm{L})$, $\mathrm{RSD}=0.028, \mathrm{R}^{2}=0.98, \mathrm{n}=8$.

Acknowledgements: Financial support was provided by the Spanish Ministerio de Educación y Ciencia (Proyecto AGL2006-07596). Authors thank Dr. J. García from the Universidad Politécnica de Madrid (Spain) for the analyses of ytterbium.

\section{References}

AOAC, 2000. Official methods of analysis of the AOAC International, $17^{\text {th }}$ ed., AOAC International, Gaithersburg, MD (USA). 
Batey, I.L., 1982. Starch analysis using thermostable alpha-amylases. Starch/Stärke 34, 125-128.

Blas, E., Gidenne, T., 2010. Digestion of sugars and starch. In: De Blas, C., Wiseman, J. (Eds.), Nutrition of the Rabbit, $2^{\text {nd }}$ ed., CAB International, Wallingford (UK), pp. 19-38.

Boletín Oficial del Estado, 2005. Real Decreto 1201/2005 sobre protección de los animales utilizados para experimentación y otros fines científicos. BOE 242, 34367-34391.

Candau, M., Delpon, G., Fioramonti, J., 1978. Influence de la nature des glucides membranaires sur le développement anatomo-fonctionnel du tractus digestif du lapin. Proc. $2^{\text {èmes }}$ Journées Recherche Cunicole. Toulouse (France), comm. 1, 4 pp.

Carabaño, R., Motta-Ferreira, W., De Blas, J.C., Fraga, M.J., 1997. Substitution of sugarbeet pulp for alfalfa hay in diets for growing rabbits. Anim. Feed Sci. Technol. 65, 249-256.

Carabaño, R., García, J., De Blas, J.C., 2001. Effect of fibre source on ileal apparent digestibility of non-starch polysaccharides in rabbits. Anim. Sci. 72, 343-350.

Carabaño, R., Villamide, M.J., García, J., Nicodemus, N., Llorente, A., Chamorro, S., Menoyo, D., García-Rebollar, P., García-Ruiz, A.ı, De Blas, J.C., 2009. New concepts and objectives for protein-amino acid nutrition in rabbits: a review. World Rabbit Sci. 17, 1-14.

Chamorro, S., Gómez-Conde, M.S., Pérez de Rozas, A.M., Badiola, I., Carabaño, R., De Blas, J.C., 2007. Effect on digestion and performance of dietary protein content and of increased substitution of lucerne hay with soyabean protein concentrate in starter diets for young rabbits. Animal 1 , 651-659. 
Chamorro, S., De Blas, J.C., Grant G., Badiola, I., Menoyo, D., Carabaño, R., 2010. Effect of dietary supplementation with glutamine and a combination of glutamine-arginine on intestinal health in twenty-five-day-old weaned rabbits. J. Anim. Sci. 88, 170-180.

De Blas, J.C., García, J., Carabaño, R., 1999. Role of fibre in rabbit diets. A review. Ann. Zootech. 48, 3-13.

Falcão-e-Cunha, L., Peres, H., Freire, J.P.B., Castro-Solla, L., 2004. Effects of alfalfa, wheat bran or beet pulp, with or without sunflower oil, on caecal fermentation and on digestibility in the rabbit. Anim. Feed Sci. Tech. 117, 131-149.

Fernández-Carmona, J., Blas, E., Pascual, J.J., Maertens, L., Gidenne, T., Xiccato, G., García, J., 2005. Recommendations and guidelines for applied nutrition experiments in rabbits. World Rabbit Sci. 13, 209-228.

Fraga, M.J., Pérez de Ayala, P., Carabaño, R., De Blas, J.C., 1991. Effect of type of fiber on the rate of passage and on the contribution of soft feces to nutrient intake of finishing rabbits. J. Anim. Sci. 69, 1566-1574.

García, G., Gálvez, J.F., De Blas, J.C., 1993. Effect of substitution of sugarbeet pulp for barley in diets for finishing rabbits on growth performance and on energy and nitrogen efficiency. J. Anim. Sci. 71, 1823-1830.

García, J., Carabaño, R., De Blas, J.C., 1999. Effect of fiber source on cell wall digestibility and rate of passage in rabbits. J. Anim. Sci. 77, 898-905.

García, J., Gidenne, T., Falcão-e-Cunha, L., De Blas, J.C., 2002. Identification of the main factors that influence caecal fermentation traits in growing rabbits. Anim. Res. 51, 165-173.

Gidenne, T., 1992. Effect of fibre level, particle size and adaptation period on digestibility and rate of passage as measured at the ileum and in the faeces in the adult rabbit. Br. J. Nutr. 67, 133-146. 
Gidenne, T., Bellier, R., 2000. Use of digestible fibre in replacement to available carbohydrates. Effect on digestion, rate of passage and caecal fermentation pattern during the growth of the rabbit. Livest. Prod. Sci. 63, 141-152.

Gidenne, T., García, J., 2006. Nutritional strategies improving the digestive health of the weaned rabbit. In: Maertens, L., Coudert, P. (Eds.). Recent Advances in Rabbit Sciences, ILVO, Melle (Belgium), pp. 229-238.

Gidenne, T., Jehl, N., 1996. Replacement of starch by digestible fibre in the feed for the growing rabbit. 1 . Consequences for digestibility and rate of passage. Anim. Feed Sci. Technol. 61, 183-192.

Gidenne, T., Perez, J.M., 1994. Apports de lignines et alimentation du lapin en croissance. I. Conséquences sur la digestion et le transit. Ann. Zootech. $43,313-322$.

Gidenne, T., Perez, J.M., 2000. Replacement of digestible fibre by starch in the diet of the growing rabbit. I. Effects on digestion, rate of passage and retention of nutrients. Ann. Zootech. 49, 357-368.

Gidenne, T., Pinheiro, V., Falcão-e-Cunha, L., 2000. A comprehensive approach of the rabbit digestion: consequences of a reduction in dietary fibre supply. Livest. Prod. Sci. 64, 225-237.

Gidenne, T., Carabaño, R., García, J., De Blas, J.C., 2010a. Fibre digestion. In: De Blas, C., Wiseman, J. (Eds.), Nutrition of the Rabbit, $2^{\text {nd }}$ ed. $C A B$ International, Wallingford (UK), pp. 66-82.

Gidenne, T., García, J., Lebas, F., Licois, D., 2010b. Nutrition and feeding strategy: interactions with pathology. In: De Blas, C., Wiseman, J. (Eds.), Nutrition of the Rabbit, $2^{\text {nd }}$ ed. CAB International, Wallingford (UK), pp. 179-199. 
Gómez-Conde, M.S., García J., Chamorro, S., Eiras, P., Rebollar, P.G., Pérez de Rozas, A., Badiola, I., De Blas, J.C., Carabaño, R., 2007. Neutral detergentsoluble fiber improves gut barrier function in twenty-five-day-old weaned rabbits. J. Anim. Sci. 85, 3313-3321.

Gómez-Conde, M.S., Pérez de Rozas, A., Badiola, I., Pérez-Alba, L., De Blas, J.C., Carabaño, R., García, J., 2009. Effect of neutral detergent soluble fibre on digestion, intestinal microbiota and performance in twenty five day old weaned rabbits. Livest. Sci. 125, 192-198.

Gutiérrez, I., Espinosa, A., García, J., Carabaño, R., De Blas, J.C., 2003. Effect of protein source on digestion and growth performance of early-weaned rabbits. Anim. Res. 52, 461-471.

Hall, M.B., Lewis, B.A., Van Soest, P.J., Chase, L.E., 1997. A simple method for estimation of neutral detergent-soluble fibre. J. Sci. Food Agric. 74, 441449.

Jehl, N., Gidenne, T., 1996. Replacement of starch by digestible fibre in feed for the growing rabbit. 2. Consequences for microbial activity in the caecum and on incidence of digestive disorders. Anim. Feed Sci. Tech. 61, 193204.

Marounek, M., Vook, S.J., Skrivanová, V., 1995. Distribution of activity of hydrolytic enzymes in the digestive tract of rabbits. Br. J. Nutr. 73, 463469.

Martínez-Vallespín, B., Martínez-Paredes, E., Ródenas, L., Cervera, C., Pascual, J.J., Blas, E., 2011. Combined feeding of rabbit female and young: partial replacement of starch with acid detergent fibre or/and neutral detergent soluble fibre at two protein levels. Livest. Sci. 141, 155-165.

Soler, M.D., Blas, E., Biglia, S., Casado, C., Moya, J., Cervera, C., 2006. Digestibilidad ileal de piensos con distinto contenido en fibra digestible, almidón y grasa animal en gazapos en postdestete. Proc. XXXI Symposium Cunicultura (ASESCU), Lorca (Spain), 73-77. 
Statistical Analysis Systems Institute, 2002. User's guide, Release 9.1. SAS Institute Inc, Cary, NC (USA).

Trocino, A., Fragkiadakis, M., Radaelli, G., Xiccato, G., 2010. Effect of dietary soluble fibre level and protein source on growth, digestion, caecal activity and health of fattening rabbits. World Rabbit Sci. 18, 199-210.

Trocino, A., Fragkiadakis, M., Majolini, D., Carabaño, R., Xiccato, G., 2011. Effect of the increase of dietary starch and soluble fibre on digestive efficiency and growth performance of meat rabbits. Anim. Feed Sci. Technol. 165, 265-277.

Van Soest, P.J., Robertson, J.R., Lewis, B.A., 1991. Methods for dietary fiber, neutral detergent fiber and nonstarch polysaccharides in relation to animal nutrition. J. Dairy Sci. 74, 3583-3597.

Villamide, M.J., Nicodemus, N., Fraga, M.J., Carabaño, R., 2010. Protein digestion. In: De Blas, C., Wiseman, J. (Eds.), Nutrition of the Rabbit, $2^{\text {nd }}$ ed., CAB International, Wallingford (UK), pp. 39-55.

Volek, Z., Marounek, M., Skrivanova, V., 2005. Replacing starch by pectin and inulin in diet of early-weaned rabbits: effect on performance, health and nutrient digestibility. J. Anim. Feed Sci. 14, 327-337.

Xiccato, G., Trocino, A., Majolini, D., Fragkiadakis, M., Tazzoli, M., 2011. Effect of decreasing dietary protein level and replacing starch with soluble fibre on digestive physiology and performance of growing rabbits. Animal 5, 1179-1187. 



\title{
Use of a weaning diet in combined feeding of females and young rabbits under two reproductive systems
}

\author{
B. Martínez-Vallespín, E. Martínez-Paredes, L. Ródenas, C. Cervera, J.J. Pascual, \\ E. Blas
}

Institute of Animal Science and Technology. Universidad Politécnica de Valencia, Camino de Vera s/n. 46022 Valencia, Spain.

\begin{abstract}
The effects of using a less concentrated weaning diet in combined feeding and of delaying the insemination and the weaning age on the performance and body condition of females and on the mortality of young rabbits were studied during five productive cycles. A total of 188 rabbit does and their litters were involved in the experiment; they were distributed in 4 groups in a factorial design, with 2 feeding systems (FS) and 2 reproductive systems (RS). Groups C28 and C42 were kept on a conventional FS, females receiving a commercial reproduction diet (diet R) during the whole experiment and young rabbits receiving this diet until weaning and a commercial growing diet (diet $\mathrm{G}$ ) until $60^{\text {th }}$ day of age; groups E28 and E42 were kept on an experimental FS, females receiving a less concentrated weaning diet (diet E) from $18^{\text {th }}$ day post-partum (dpp) until weaning and young rabbits receiving this diet from $18^{\text {th }}$ to $49^{\text {th }}$ day of age, when they were switched to diet $G$ until $60^{\text {th }}$ day of age. Groups C28 and E28 were managed in a semi-intensive RS: insemination at $11^{\text {th }} \mathrm{dpp}$ and weaning at $28^{\text {th }} \mathrm{dpp}$; groups C42 and E42 were managed in an extensive RS: insemination at $25^{\text {th }} \mathrm{dpp}$ and weaning at $42^{\text {nd }} d p p$. In primiparous pregnant rabbit does, both milk yield during the $4^{\text {th }}$ week of lactation and perirenal fat thickness (PFT) change from
\end{abstract}


insemination to weaning impaired in E28 in comparison with C28 $(-20 \pm 10$ $\mathrm{g} / \mathrm{d}, \quad P=0.057 ; \quad-0.487 \pm 0.153 \mathrm{~mm}, \quad P<0.01) ; \quad$ in primiparous rabbit does becoming pregnant at $25^{\text {th }} \mathrm{dpp}$, feed intake during the $4^{\text {th }}$ week was higher in E42 than in C42 $(+52 \pm 8 \mathrm{~g}$ dry matter, DM/d, $P<0.01)$; PFT loss from $1^{\text {st }}$ to $2^{\text {nd }}$ parturition was higher in E42 than in the rest of groups $(-0.229 \pm 0.110$, $P<0.05)$. In multiparous rabbit does, milk yield was lower in E28 than in C28 during the $4^{\text {th }}$ and $5^{\text {th }}$ lactations $\left(-27 \pm 8 \mathrm{~g} / \mathrm{d}, P<0.01\right.$, from parturition to $18^{\text {th }}$ $\mathrm{dpp} ;-28 \pm 12 \mathrm{~g} / \mathrm{d}, P<0.05$, during the $4^{\text {th }}$ week) and in E42 than in C42 during the $3^{\text {rd }}$ and $4^{\text {th }}$ lactations $\left(-17 \pm 7 \mathrm{~g} / \mathrm{d}, P<0.05\right.$, from parturition to $18^{\text {th }} \mathrm{dpp}$; $-24 \pm 11 \mathrm{~g} / \mathrm{d}, P<0.05$, during the $4^{\text {th }}$ week); no differences were found in PFT changes from parturition to weaning, from weaning to next parturition and between consecutive parturitions depending on FS; litter size at birth was lower in E42 than in C42 $(-1.15 \pm 0.49, P<0.05)$; in comparison with the semiintensive RS, the extensive RS reduced feed intake in the $4^{\text {th }}$ and $5^{\text {th }}$ cycles $\left(-45 \pm 9 \mathrm{~g} \mathrm{DM} / \mathrm{d}, P<0.001\right.$, from parturition to $18^{\text {th }} \mathrm{dpp} ;-38 \pm 13 \mathrm{~g} \mathrm{DM} / \mathrm{d}$, $P<0.01$, in the $4^{\text {th }}$ week of lactation; $-20 \pm 7 \mathrm{~g} \mathrm{DM} / \mathrm{d}, P<0.01$, in pregnancy); no differences were found in PFT change from parturition to weaning, from weaning to next parturition and between consecutive parturitions depending on RS but increases of live weight of rabbit does between consecutive parturitions in the $4^{\text {th }}$ and $5^{\text {th }}$ cycles were lower in the extensive than in the semi-intensive RS $(-123 \pm 37 \mathrm{~g}, P<0.001)$; at the $4^{\text {th }}, 5^{\text {th }}$ and $6^{\text {th }}$ parturitions, litter weight at birth was lower in the extensive than in the semi-intensive RS $(-61 \pm 19 \mathrm{~g}, P<0.01)$; the individual live weight of kits at birth was lower in the extensive than in the semi-intensive RS $(-3.0 \pm 1.2 \mathrm{~g}, P<0.05)$ and mortality of kits at birth was lower in the extensive than in the semi-intensive RS (7.5 vs. $9.6 \%, P<0.001)$. In a context of Epizootic Rabbit Enteropathy, mortality rate of growing rabbits from 28 to 42 days was lower in the extensive than in the semi-intensive RS $(-26.1 \%, P<0.001)$; from 42 to 60 days, lower mortality rate was recorded with the experimental FS $(-11.4 \%, P<0.001)$ and in the semiintensive RS $(-9.3 \%, P<0.001)$; the accumulated mortality from 28 to 60 days was reduced with both experimental FS and extensive RS $(-8.7 \%$ and $-12.8 \%$, 
respectively, $P<0.001)$. The negative effects of the experimental FS and of the extensive RS on performance of rabbit does could illustrate an adaptation process to limited availability of resources and to greater physiological effort because of longer lactations; on the other hand, both strategies were beneficial for digestive health of growing rabbits.

Keywords: rabbit, combined feeding, weaning diet, reproductive system 


\section{Introduction}

The high incidence of digestive disorders, especially of Epizootic Rabbit Enteropathy (ERE) in commercial farms (Le Bouquin et al., 2009; Rosell et al., 2009) have led to propose new feeding strategies to promote digestive health of young rabbits, as mainly the development of specific diets for the period around weaning or feed restriction after weaning (Gidenne and FortunLamothe, 2002; Gidenne et al., 2010). As a practical approach, it has been suggested the possible supply of these weaning diets in combined feeding of females and young rabbits in late lactation and also in the initial phase of growing period. In that respect, Martínez-Vallespín et al. (2011) observed -in an ERE context- that less concentrated weaning diets reduced the mortality rate of growing rabbits but impaired milk yield and body condition of females at weaning, since high nutritive requirements of rabbits does selected for high performance requires the use of concentrated diets (Pascual et al., 2003).

On the other hand, a clear trend to change the usual reproductive management delaying both insemination and weaning has been observed in field conditions in the last years, because of an empiric decrease in mortality rate of young rabbits during the growth period, which could be explained by the protective role of rabbit milk against some pathogens (Gallois et al., 2007). However, longer lactations could compromise the productive career of rabbit does by exacerbating their negative energy balance (Xiccato et al., 2004).

No information is available about the long term effects of the use of less concentrated weaning diets in combined feeding and of the delay of insemination and weaning on the performance and body condition of females and on the mortality of young rabbits. Consequently, the aim of this work is to study, in a factorial design, the effects of both strategies during five productive cycles. 


\section{Material and Methods}

\section{Experimental design}

A total of 188 primiparous rabbit does (crossbred from the maternal lines $A$ and $V$, Universidad Politécnica de Valencia) and their litters during 5 consecutive cycles (until $6^{\text {th }}$ parturition) were involved in the experiment. They were distributed in 4 groups in a factorial design, with 2 feeding systems (FS) and 2 reproductive systems (RS). Groups C28 and C42 were kept on a conventional FS, females receiving a commercial reproduction diet (diet $\mathrm{R}$ ) during the whole experiment and young rabbits receiving this diet until weaning and a commercial growing diet (diet $\mathrm{G}$ ) until $60^{\text {th }}$ day of age; groups E28 and E42 were kept on an experimental FS, females receiving a less concentrated weaning diet (diet E) from $18^{\text {th }}$ day post-partum (dpp) until weaning and young rabbits receiving this diet from $18^{\text {th }}$ to $49^{\text {th }}$ day of age, when they were switched to diet $G$ until $60^{\text {th }}$ day of age. Groups C28 and E28 were managed in a semi-intensive RS: insemination at $11^{\text {th }} \mathrm{dpp}$ and weaning at $28^{\text {th }} \mathrm{dpp}$; groups $\mathrm{C} 42$ and E42 were managed in an extensive RS: insemination at $25^{\text {th }} \mathrm{dpp}$ and weaning at $42^{\text {nd }} \mathrm{dpp}$. The rabbit does were inseminated in weekly batches with pooled semen (growth line R, Universidad Politécnica de Valencia) at mentioned dates and each 21 days afterwards if needed. Figure 1 illustrates the scheme of the experimental design.

Tables 1 and 2 show the ingredients and chemical composition of the diets. Diet $\mathrm{E}$ was a less concentrated diet, rich in acid detergent fibre (ADF) and neutral detergent soluble fibre (NDSF), low in starch and with a crude protein (CP) content lower than the diet $R$ and similar to the diet $G$, formulated to promote digestive health of young rabbits according to the results obtained in a previous work (Martínez-Vallespín et al., 2011). All diets included zinc bacitracin (100 ppm) and robenidine (66 ppm). 


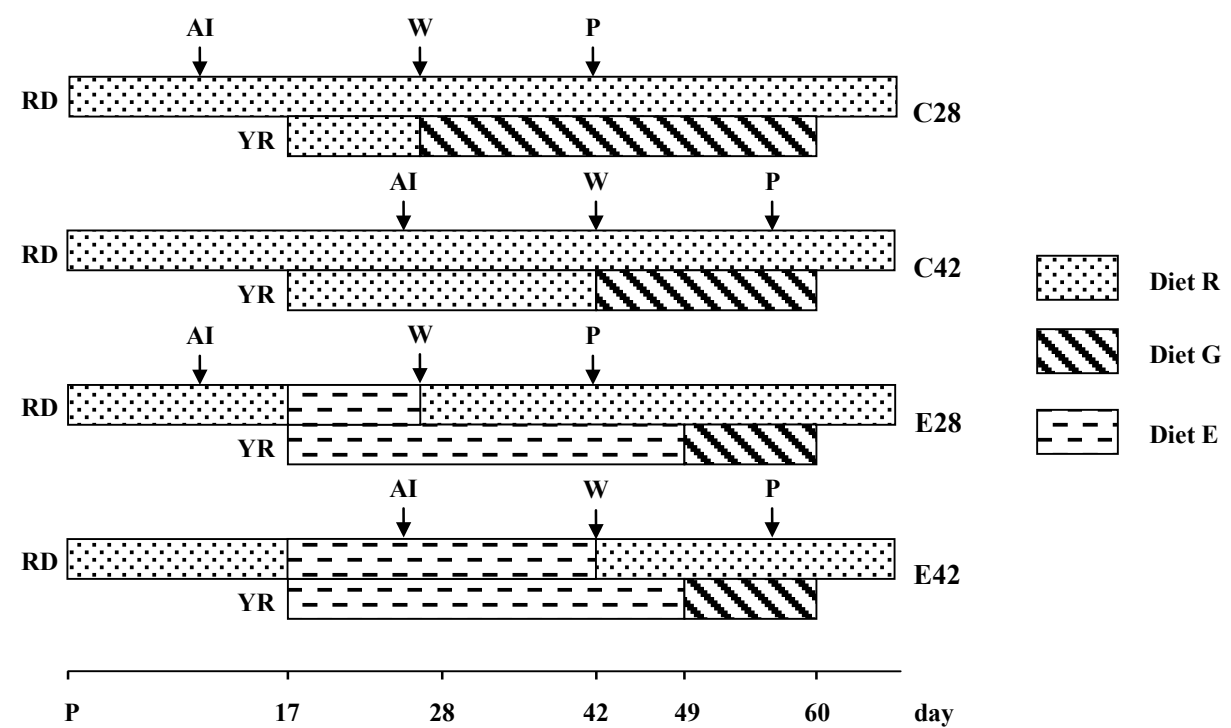

Figure 1. Management of experimental groups. RD: rabbit does; YR: young rabbits; P: parturition; Al: artificial insemination; W: weaning; C28: conventional feeding system and semi-intensive reproductive system; C42: conventional feeding system and extensive reproductive system; E28: experimental feeding system and semi-intensive reproductive system; E42: experimental feeding system and extensive reproductive system; diet R: commercial reproduction diet; diet G: commercial growing diet; diet E: weaning diet.

Table 1. Ingredient composition of the diets ( $\mathrm{g} / \mathrm{kg}$ dry matter)

\begin{tabular}{lccc}
\hline Diets & Diet R & Diet G & Diet E \\
\hline Barley & 96 & 103 & - \\
Wheat bran & 300 & 352.5 & - \\
Sunflower meal 28 & 201 & 125 & 177.5 \\
Soybean protein concentrate 61 & - & - & 37.5 \\
Fish meal 70 & - & - & 23.75 \\
Lucerne & 300 & 300 & - \\
Beet pulp & - & - & 240 \\
Oat hulls & - & - & 150 \\
Defatted grape seed & - & - & 180 \\
Grape pomace & - & - & 10 \\
Treated wheat straw & 30 & 59 & 63.75 \\
Soybean oil & - & - & 50 \\
Animal fat & 19 & 7.5 & - \\
Sugarcane molasses & 41 & 40 & 10 \\
Corn starch & - & - & 10 \\
L-Lysine HCl & 2.3 & 1.8 & 4.75 \\
DL-Methionine & 0.5 & - & 2.75 \\
L-Threonine & 1 & 1 & 2.5 \\
L-Tryptophan & - & - & 1.875 \\
Calcium carbonate & 2.2 & 2.2 & 3.875 \\
Dicalcium phosphate & - & - & 22.75 \\
Sodium chloride & 3 & 4 & 5 \\
Vitamin/trace element premix & 4 & 4 & 4 \\
\hline
\end{tabular}

${ }^{1}$ Diet R: commercial reproduction diet (囚Cunilactal-UPV); Diet G: commercial growing diet ( $($ Cunimed-UPV); Diet E: weaning diet. Both commercial diets had ingredient composition constant for the experimental period and were provided by NANTA, Camino del Machistre, Meliana, Spain

${ }^{2}$ Supplied per kg of feed: Vitamin A: 8.375 IU; Vitamin D3: 750 IU; Vitamin E: 20 mg; Vitamin K3: 1 mg; Vitamin $\mathrm{B}_{1}: 1 \mathrm{mg}$; Vitamin $\mathrm{B}_{2}: 2 \mathrm{mg}$; Vitamin $\mathrm{B}_{6}: 1 \mathrm{mg}$; Nicotinic acid: $20 \mathrm{mg}$; Choline chloride: $250 \mathrm{mg}$; Magnesium: 290 mg; Manganese: 20 mg; Zinc: 60 mg; lodine: 1.25 mg; Iron: 26 mg; Copper: 10 mg; Cobalt: $0.7 \mathrm{mg}$; Butyl hydroxylanysole and ethoxiquin mixture: $4 \mathrm{mg}$. 
Chemical analyses were performed according to the methods of the AOAC (2000): 934.01 for dry matter (DM), 942.05 for ash, 976.06 for CP and 920.39 for ether extract, with acid-hydrolysis of samples prior to the extraction. Starch content was determined according to Batey (1982), by a two-step enzymatic procedure with solubilisation and hydrolysis to maltodextrins with thermo-stable $\alpha$-amylase followed by complete hydrolysis with amyloglucosidase (both enzymes from Sigma-Aldrich, Steinheim, Germany), and the resulting glucose being measured by the hexokinase/glucose-6 phosphate dehydrogenase/NADP system (R-Biopharm, Darmstadt, Germany). Neutral detergent fibre (NDF), ADF and acid detergent lignin (ADL) fractions were analysed sequentially (Van Soest et al., 1991) with a thermo-stable $\alpha$-amylase pre-treatment and expressed exclusive of residual ash, using a nylon filter bag system (Ankom, Macedon, NY, USA). NDSF content was determined according to Hall et al. (1997), adapting the method to the nylon filter bag system and with the following modifications: a Soxhlet extraction of the samples with petroleum ether (6 hours) was performed prior to the ethanol-water extraction and the NDF fraction was determined from the ether-ethanol insoluble residue instead of from the raw sample.

Table 2. Chemical composition of the diets ( $\mathrm{g} / \mathrm{kg}$ dry matter)

\begin{tabular}{lccc}
\hline Diets $^{1}$ & Diet R & Diet G & Diet E \\
\hline Organic matter & 912 & 908 & 924 \\
Crude protein & 170 & 162 & 162 \\
Ether extract & 36 & 34 & 78 \\
Starch & 135 & 143 & 31 \\
Neutral detergent fibre, NDF & 391 & 401 & 498 \\
Acid detergent fibre, ADF & 191 & 196 & 300 \\
Acid detergent lignin, ADL & 35 & 36 & 112 \\
Insoluble hemicelluloses, NDF-ADF & 200 & 205 & 198 \\
Cellulose, ADF-ADL & 156 & 160 & 188 \\
Neutral detergent soluble fibre & 112 & 121 & 174 \\
Digestible energy $^{2}$ (MJ/kg dry matter) & 10.9 & 10.5 & 10.0 \\
\hline
\end{tabular}

${ }^{1}$ Diet R: commercial reproduction diet ( $($ Cunilactal-UPV); Diet G: commercial growing diet (®Cunimed-UPV); Diet E: weaning diet.

${ }^{2}$ Calculated according to Villamide et al. (2010) and Fundación Española para el Desarrollo de la Nutrición Animal (2010). 


\section{Animal housing and management}

The experimental protocols followed both the Spanish Royal Decree 1201/2005 on the protection of animals used for scientific purposes (Boletín Oficial del Estado, 2005) and the recommendations for applied nutrition research in rabbits described by the European Group on Rabbit Nutrition (Fernández-Carmona et al., 2005), having been approved by the Committee of Ethics and Animal Welfare of the Universidad Politécnica de Valencia.

Animals were housed in an experimental farm having a history of ERE. The building was equipped with a forced ventilation and cooling system to maintain the temperature within the range of 12 to $25^{\circ} \mathrm{C}$ throughout the experimental period (May to July of the following year). A photoperiod of 16 hours of light and 8 hours of darkness was established using artificial lights just in the months in which was needed. A lactation trial was carried out in the breeding unit, equipped with cages which dimensions were $50 \times 70 \times 32 \mathrm{~cm}$ and provided with nesting boxes, and a growing trial was conducted in the fattening unit using collective cages $(50 \times 80 \times 32 \mathrm{~cm})$.

Litters were standardized at birth to 8-9 kits or 10-12 kits in primiparous and multiparous rabbit does, respectively. Nesting boxes were closed from birth to $21^{\text {th }} \mathrm{dpp}$, except for the weekends, and once daily in the morning rabbit does were allowed to go into them to suckle and control the milk production by weighing the doe immediately before and after suckling. At $21^{\text {th }}$ $\mathrm{dpp}$, the nesting boxes were opened and females were lodged separate from their litters and taken to the litter cage once daily in the morning to continue with the milk production control until weaning as described above.

Perirenal fat thickness (PFT) of females was measured at parturition, insemination and weaning by echography (Pascual et al., 2000), using an ultrasound unit (JustVision 200, Toshiba Medical Systems, Tokyo, Japan) equipped with image analyser software to determine distances. Feed intake of females was controlled at $7^{\text {th }}, 14^{\text {th }}, 18^{\text {th }}$ and $25^{\text {th }}$ dpp in groups C28 and E28 
and also at $32^{\text {nd }}$ and $39^{\text {th }} \mathrm{dpp}$ in groups C42 and E42. Litter size and weight were registered at birth and weekly until weaning and solid feed intake during lactation was monitored from $18^{\text {th }} \mathrm{dpp}$ to weaning at the same days as indicated for females. Finally, mortality of young rabbits from weaning to 60 days of age was daily registered.

\section{Statistical analysis}

Data were analysed with the SAS software (Statistical Analysis Systems Institute, 2002), separately for primiparous and multiparous rabbit does. A GLM procedure was used in primiparous rabbit does, the model including the FS (conventional or experimental), the RS (semi-intensive or extensive), the concurrence of lactation and pregnancy (yes or not) and the interactions between these factors; live weight and PFT of rabbit does at parturition were included as covariates, as well as size and weight of standardized litters. A MIXED procedure was used in multiparous rabbit does in a repeated measure design that took into account the variation between animals and covariation within them. An autoregressive structure with animals combined with a random effect between animals was used to model the covariance structure of the data (Littell et al., 1998). The model included the FS, the RS, the parity order (PO, from 2 to 6) as repeated measure factor, the concurrence of lactation and pregnancy in both the previous and the current productive cycle, the interactions between these factors, with a permanent effect of each rabbit doe (nested to FS $\times$ RS) and the error as random factors. Size and weight of standardized litters were included as covariates. Different mean contrasts were computed to test the significance of the differences between FS $[(\mathrm{E} 28+\mathrm{E} 42) / 2-(\mathrm{C} 28+\mathrm{C} 42) / 2]$ and RS [(C42+E42)/2-(C28+E28)/2]. A GENMOD procedure was used to analyse fertility and culling rates of rabbit does, as well as mortality rate of young rabbits. For fertility in primiparous does and culling rate the model included the FS, the RS and their interaction, while for fertility of multiparous does and mortality of young rabbits the model also included a permanent effect of the rabbit doe as random effect. 


\section{Results}

\section{Primiparous rabbit does and suckling rabbits}

Tables 3 and 4 show the performance of primiparous rabbit does and their litters until weaning, respectively.

No significant differences were found in the feed intake of rabbit does during the $4^{\text {th }}$ week of lactation in function of the FS or RS; however, in rabbit does becoming pregnant at $25^{\text {th }} \mathrm{dpp}$, feed intake was higher in those from E42 than from C42 $(+52 \pm 8 \mathrm{~g} \mathrm{DM} / \mathrm{d}, P=0.004)$, whereas no differences were observed between them when insemination was not effective. Feed intake of rabbit does was higher in E42 than in C42 during the two last weeks of lactation (+15\%). Feed intake in the $2^{\text {nd }}$ pregnancy was higher for rabbit does of E42 than in the rest $(+19 \pm 6 \mathrm{~g} \mathrm{DM} / \mathrm{d}, P<0.001)$. Milk yield during the $4^{\text {th }}$ week of lactation was lower in concurrent pregnant rabbit does from E28 than from C28 $(-20 \pm 10 \mathrm{~g} / \mathrm{d}, P=0.057)$, whereas no difference was found between them when non-pregnant. No difference was found in milk yield between $\mathrm{C} 42$ and E42 during the last two weeks of lactation.

A lower live weight increase of rabbit does from parturition to weaning was observed for E42 than for C42 $(-155 \pm 53 \mathrm{~g}, P=0.004)$; on the other hand, this trait was lower in rabbit does under extensive than under semi-intensive RS. Increase in live weight from weaning to next parturition was higher in E42 than in C42 $(+106 \pm 51 \mathrm{~g}, P=0.041)$; on the other hand, this trait was higher in rabbit does under extensive than under semi-intensive RS. Increase in live weight from $1^{\text {st }}$ to $2^{\text {nd }}$ parturition was unaffected by the FS and the RS. PFT change of rabbit does from parturition to weaning was impaired with the introduction of the $\mathrm{E}$ diet, being the difference close to significance $(P=0.060)$. Variation in PFT between weaning and next parturition was not affected by FS or RS. PFT loss from $1^{\text {st }}$ to $2^{\text {nd }}$ parturition was higher in E42 than in the rest $(-0.229 \pm 0.110 \mathrm{~mm}, P=0.039)$. 
Table 3. Effect of the feeding system (FS) and the reproductive system (RS) on performance of primiparous rabbit does

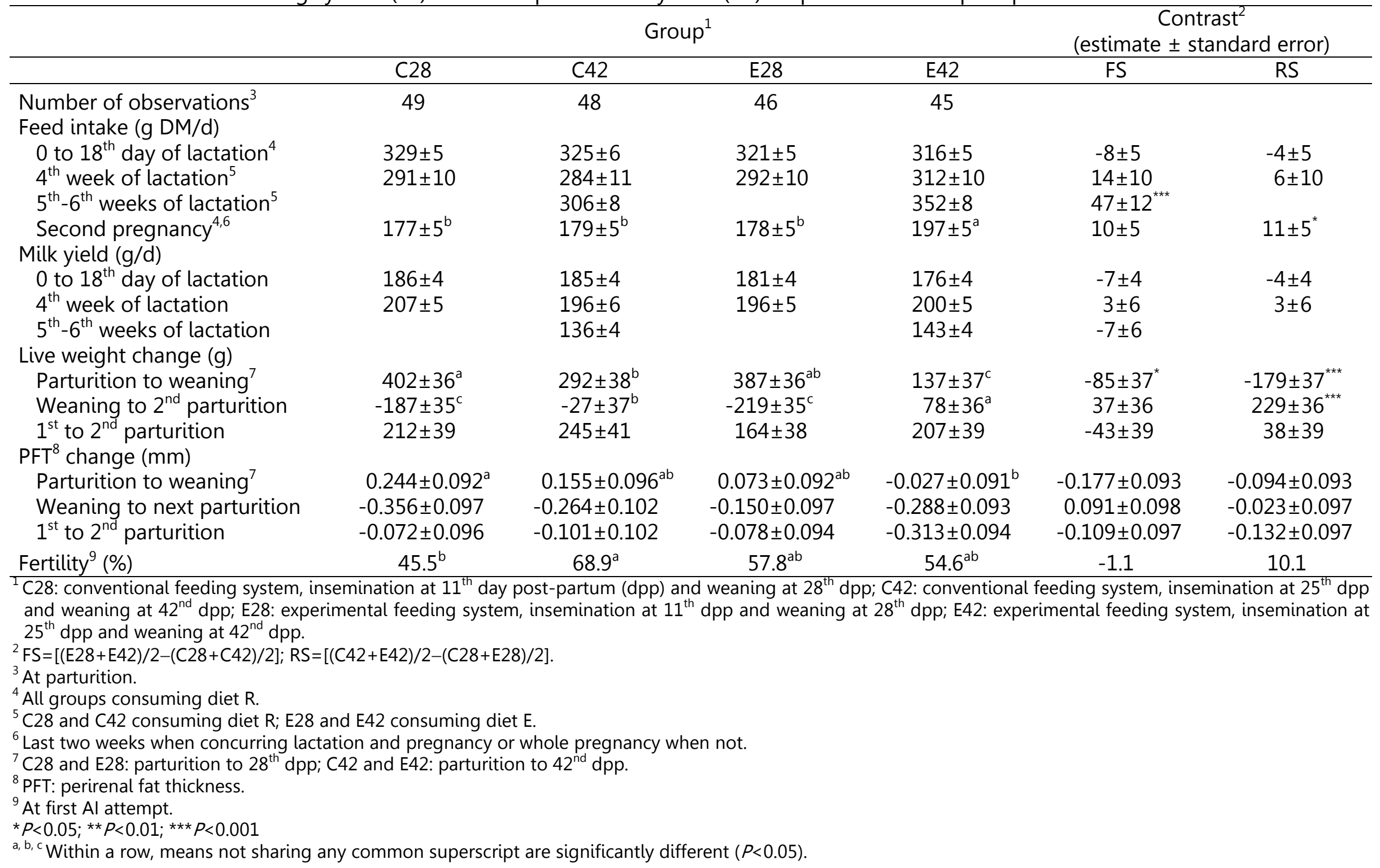


Table 4. Effect of the feeding system (FS) and the reproductive system (RS) on litters of primiparous rabbit does

\begin{tabular}{|c|c|c|c|c|c|c|}
\hline & \multicolumn{4}{|c|}{ Group $^{1}$} & \multicolumn{2}{|c|}{$\begin{array}{c}\text { Contrast }^{2} \\
\text { (estimate } \pm \text { standard error) }\end{array}$} \\
\hline & C28 & C42 & E28 & E42 & FS & RS \\
\hline Number of observations ${ }^{3}$ & 49 & 48 & 46 & 45 & & \\
\hline \multicolumn{7}{|l|}{ At birth } \\
\hline Total litter size & $9.44 \pm 0.45$ & $8.92 \pm 0.48$ & $9.59 \pm 0.44$ & $9.20 \pm 0.46$ & $0.22 \pm 0.46$ & $-0.45 \pm 0.45$ \\
\hline Total litter weight (g) & $482 \pm 15$ & $458 \pm 16$ & $483 \pm 14$ & $470 \pm 15$ & $7 \pm 15$ & $-19 \pm 15$ \\
\hline \multicolumn{7}{|l|}{ At $28^{\text {th }}$ day of lactation ${ }^{4}$} \\
\hline Litter size & $8.58 \pm 0.12$ & $8.66 \pm 0.13$ & $8.54 \pm 0.12$ & $8.56 \pm 0.12$ & $-0.07 \pm 0.12$ & $0.05 \pm 0.12$ \\
\hline Individual live weight (g) & $515 \pm 8^{a}$ & $515 \pm 9^{a}$ & $454 \pm 8^{b}$ & $455 \pm 9^{b}$ & $-61 \pm 9^{* * *}$ & $1 \pm 9$ \\
\hline Individual feed intake (g DM/d) ${ }^{5}$ & $7.8 \pm 0.4^{a}$ & $7.2 \pm 0.4^{\mathrm{a}}$ & $4.1 \pm 0.4^{b}$ & $3.4 \pm 0.4^{b}$ & $-3.7 \pm 0.4^{\star \star \star}$ & $-0.6 \pm 0.4$ \\
\hline \multicolumn{7}{|l|}{ At $42^{\text {nd }}$ day of lactation ${ }^{4}$} \\
\hline Litter size & & $8.53 \pm 0.14$ & & $8.34 \pm 0.14$ & $-0.19 \pm 0.20$ & \\
\hline Individual live weight (g) & & $1100 \pm 16$ & & $1003 \pm 15$ & $-97 \pm 22^{\star * *}$ & \\
\hline Individual feed intake (g DM/d) ${ }^{5}$ & & $72.6 \pm 2.2$ & & $67.3 \pm 2.1$ & $-5.3 \pm 3.1$ & \\
\hline \multicolumn{7}{|c|}{ 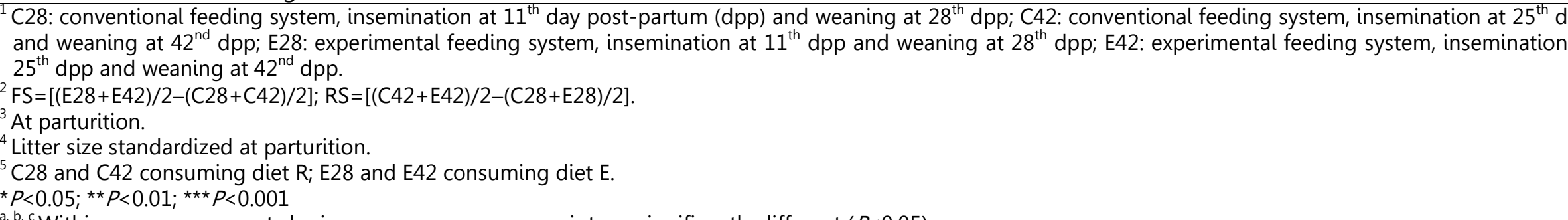 } \\
\hline
\end{tabular}


Fertility rate was not significantly different between E28 and E42; however, it was higher for C42 than for C28 $(P=0.027)$.

Although no differences were observed in litter size, live weight of young rabbits at $28^{\text {th }}$ day of lactation was reduced in the experimental FS $(-12 \%)$, as well as their feed intake during the $4^{\text {th }}$ week of lactation $(-49 \%)$. No significant effect of RS on feed intake of litters was observed. No significant differences were found in litter size at $42^{\text {nd }}$ day of lactation between C42 and E42, but live weight of young rabbits was lower in E42 than in C42 (-8.8\%). Feed intake of litters during the two last weeks of lactation was lower in E42 than in C42 the difference being close to significance $(P=0.086)$.

\section{Multiparous rabbit does and suckling rabbits}

Tables 5 and 6 show performance of multiparous rabbit does and their litters until weaning respectively.

From parturition to $18^{\text {th }} \mathrm{dpp}$, female feed intake was unaffected by the FS whereas it was lower in the extensive than in the semi-intensive RS (-5.2\%); moreover, an interaction was detected between RS and PO, as shown in Figure $2 a$, in such a way that differences were only observed in the $4^{\text {th }}$ and $5^{\text {th }}$ lactations $(-45 \pm 9 \mathrm{~g} \mathrm{DM} / \mathrm{d}, P<0.001)$. During the $4^{\text {th }}$ week of lactation, rabbit does under experimental FS showed higher feed intake (+6.7\%), the differences being significant only between E42 and C42 $(+36 \pm 13 \mathrm{~g} \mathrm{DM} / \mathrm{d}$, $P=0.008)$; similarly to the previous period, an interaction was detected between RS and PO, in such a way that differences were only observed in the $4^{\text {th }}$ and $5^{\text {th }}$ lactations $(-38 \pm 13 \mathrm{~g} \mathrm{DM} / \mathrm{d}, P=0.004)$. Feed intake during the two last weeks of lactation was higher in E42 than in C42 (+8.5\%). Figure 2b shows feed intake in pregnancy (two last weeks of pregnancy for concurrent lactating-pregnant does and whole pregnancy for those non-concurrent), illustrating the same pattern described for lactation -lower feed intake in the extensive than in the semi-intensive RS in $5^{\text {th }}$ and $6^{\text {th }}$ pregnancies $(-20 \pm 7 \mathrm{~g}$ $\mathrm{DM} / \mathrm{d}, P=0.003)-$. 
Table 5. Effect of the feeding system (FS) and the reproductive system (RS) on performance of multiparous rabbit does

\begin{tabular}{|c|c|c|c|c|c|c|c|}
\hline & \multicolumn{4}{|c|}{ Group $^{1}$} & \multicolumn{2}{|c|}{$\begin{array}{c}\text { Contrast }^{2} \\
\text { (estimate } \pm \text { standard error) }\end{array}$} & \multirow[t]{2}{*}{ Interactions ${ }^{3}$} \\
\hline & $\mathrm{C} 28$ & C42 & E28 & E42 & FS & RS & \\
\hline Number of observations ${ }^{4}$ & $196(46)$ & $198(45)$ & $194(43)$ & $174(45)$ & & & \\
\hline \multicolumn{8}{|l|}{ Feed intake (g DM/d) } \\
\hline 0 to $18^{\text {th }}$ day of lactation ${ }^{5}$ & $419 \pm 7^{a}$ & $391 \pm 7^{b}$ & $411 \pm 7^{\mathrm{ab}}$ & $395 \pm 7^{b}$ & $-2 \pm 7$ & $-22 \pm 7^{\star *}$ & $\mathrm{RS} \times \mathrm{PO} \mathrm{O}^{\star \star \star}$ \\
\hline $4^{\text {th }}$ week of lactation 6 & $381 \pm 9^{a b}$ & $361 \pm 9^{b}$ & $395 \pm 9^{a}$ & $397 \pm 10^{a}$ & $25 \pm 9^{* *}$ & $-9 \pm 9$ & $\mathrm{RS} \times \mathrm{PO}^{\star * \star}$ \\
\hline $5^{\text {th }}-6^{\text {th }}$ week of lactation ${ }^{6}$ & & $369 \pm 9$ & & $400 \pm 10$ & $31 \pm 14^{*}$ & & \\
\hline Next pregnancy ${ }^{5,7}$ & $200 \pm 5^{a b}$ & $187 \pm 5^{b}$ & $205 \pm 5^{a}$ & $198 \pm 5^{a b}$ & $8 \pm 5$ & $-10 \pm 5$ & $\mathrm{RS} \times \mathrm{PO}^{*}$ \\
\hline \multicolumn{8}{|l|}{ Milk yield $(\mathrm{g} / \mathrm{d})$} \\
\hline 0 to $18^{\text {th }}$ day of lactation & $252 \pm 4^{a}$ & $243 \pm 4^{a b}$ & $235 \pm 4^{b}$ & $236 \pm 4^{b}$ & $-12 \pm 4^{\star *}$ & $-4 \pm 4$ & $\mathrm{FS} \times \mathrm{RS} \times \mathrm{PO}^{*}$ \\
\hline $4^{\text {th }}$ week of lactation & $261 \pm 6$ & $256 \pm 5$ & $246 \pm 6$ & $246 \pm 7$ & $-12 \pm 6^{*}$ & $-3 \pm 6$ & \\
\hline $5^{\text {th }}-6^{\text {th }}$ week of lactation & & $165 \pm 5$ & & $176 \pm 5$ & $10 \pm 8$ & & \\
\hline \multicolumn{8}{|l|}{ Live weight change (g) } \\
\hline Parturition to weaning ${ }^{8}$ & $332 \pm 30^{b}$ & $101 \pm 30^{c}$ & $422 \pm 29^{a}$ & $59 \pm 34^{c}$ & $24 \pm 31$ & $-297 \pm 31^{\star \star \star}$ & \\
\hline Weaning to next parturition & $-222 \pm 32^{b}$ & $-44 \pm 30^{a}$ & $-270 \pm 29^{b}$ & $17 \pm 35^{a}$ & $7 \pm 31$ & $233 \pm 32^{\star \star \star}$ & \\
\hline Parturition to next parturition & $117 \pm 23^{a b}$ & $66 \pm 24^{b}$ & $147 \pm 21^{\mathrm{a}}$ & $70 \pm 25^{b}$ & $17 \pm 23$ & $-64 \pm 23^{* \star *}$ & $\mathrm{RS} \times \mathrm{PO}^{*}$ \\
\hline \multicolumn{8}{|l|}{$\mathrm{PFT}^{9}$ change $(\mathrm{mm})$} \\
\hline Parturition to weaning ${ }^{8}$ & $-0.140 \pm 0.061$ & $-0.168 \pm 0.065$ & $-0.136 \pm 0.061$ & $-0.015 \pm 0.066$ & $0.079 \pm 0.064$ & $0.046 \pm 0.064$ & \\
\hline Weaning to next parturition & $0.037 \pm 0.067$ & $0.079 \pm 0.068$ & $0.054 \pm 0.064$ & $-0.028 \pm 0.072$ & $-0.045 \pm 0.068$ & $-0.020 \pm 0.069$ & \\
\hline Parturition to next parturition & $-0.074 \pm 0.046$ & $-0.053 \pm 0.048$ & $-0.091 \pm 0.042$ & $-0.037 \pm 0.049$ & $-0.001 \pm 0.046$ & $0.038 \pm 0.047$ & \\
\hline Fertility $^{10}(\%)$ & 72.6 & 78.3 & 74.1 & 74.3 & -0.6 & 3.0 & \\
\hline \multicolumn{8}{|c|}{$\begin{array}{l}{ }^{1} \text { C28: conventional feeding system, insemination at } 11^{\text {th }} \text { day post-partum (dpp) and weaning at } 28^{\text {th }} \text { dpp; C42: conventional feeding system, insemination at } 25^{\text {th }} \text { dpp } \\
\text { and weaning at } 42^{\text {nd }} \text { dpp; E28: experimental feeding system, insemination at } 11^{\text {th }} d p p \text { and weaning at } 28^{\text {th }} \text { dpp; E42: experimental feeding system, insemination at } \\
25^{\text {th }} \text { dpp and weaning at } 42^{\text {nd }} \text { dpp. }\end{array}$} \\
\hline \multicolumn{8}{|c|}{${ }^{2} \mathrm{FS}=[(\mathrm{E} 28+\mathrm{E} 42) / 2-(\mathrm{C} 28+\mathrm{C} 42) / 2] ; \mathrm{RS}=[(\mathrm{C} 42+\mathrm{E} 42) / 2-(\mathrm{C} 28+\mathrm{E} 28) / 2]$} \\
\hline \multicolumn{8}{|c|}{$\begin{array}{l}{ }^{3} \text { PO: parity order. } \\
{ }^{4} \text { At parturition. }\end{array}$} \\
\hline${ }_{5}^{4}$ At parturition. & & & & & & & \\
\hline \multicolumn{8}{|l|}{${ }^{5}$ All groups consuming diet R. } \\
\hline \multicolumn{8}{|c|}{${ }^{6} \mathrm{C} 28$ and $\mathrm{C} 42$ consuming diet $\mathrm{R} ; \mathrm{E} 28$ and E42 consuming diet $\mathrm{E}$. } \\
\hline \multicolumn{8}{|c|}{$\begin{array}{l}{ }^{7} \text { Last two weeks when concurring lactation and pregnancy or whole pregnancy when not. } \\
{ }^{8} \mathrm{C} 28 \text { and E28: parturition to } 28^{\text {th }} \mathrm{dpp}: \mathrm{C} 42 \text { and E42: parturition to } 42^{\text {nd }} \mathrm{dpp} \text {. }\end{array}$} \\
\hline \multicolumn{8}{|c|}{$\begin{array}{l}{ }^{9} \mathrm{CFT} \text { : perirenal fat thickness. } \\
\end{array}$} \\
\hline \multicolumn{8}{|l|}{${ }^{10}$ At first Al attempt. } \\
\hline \multicolumn{8}{|l|}{${ }^{*} P<0.05 ;{ }^{* *} P<0.01 ;{ }^{* * *} P<0.001$} \\
\hline
\end{tabular}



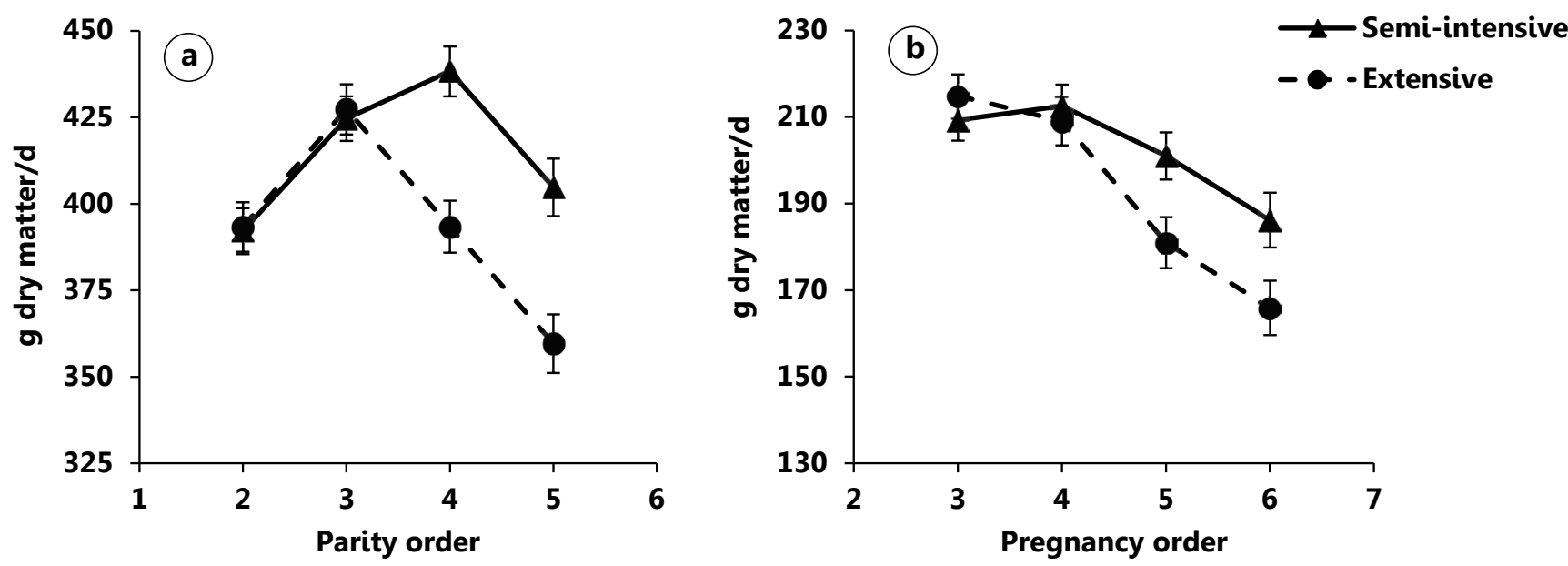

Figure 2. Feed intake in multiparous rabbit does from parturition to $18^{\text {th }}$ day post-partum (a) and during pregnancy (b) in the successive cycles. Semi-intensive reproductive system: insemination at $11^{\text {th }}$ day post-partum ( $d p p$ ) and weaning at $28^{\text {th }} \mathrm{dpp}$; extensive reproductive system: insemination at $25^{\text {th }} \mathrm{dpp}$ and weaning at $42^{\text {nd }} \mathrm{dpp}$.

As indicated in Figure 3, the previous lactation-pregnancy concurrence affected feed intake during the next lactation in a different way depending on the RS. Thus, rabbit does under semi-intensive RS presented higher feed intake during the three first weeks of lactation if they were pregnant at previous weaning $(+22 \pm 6 \mathrm{~g} \mathrm{DM} / \mathrm{d}$, $P<0.001)$ but differences disappeared in the $4^{\text {th }}$ week of lactation; in rabbit does under extensive RS, differences during the three first weeks were larger $(+39 \pm 6 \mathrm{~g}$ $\mathrm{DM} / \mathrm{d}, P<0.001)$ and persisted during the rest of lactation $(+33 \pm 10 \mathrm{~g} \mathrm{DM} / \mathrm{d}, P<0.001$, and $+25 \pm 10 \mathrm{~g} \mathrm{DM} / \mathrm{d}, P=0.009$, respectively for the $4^{\text {th }}$ and $5^{\text {th }}-6^{\text {th }}$ weeks) in favour of those pregnant at previous weaning.

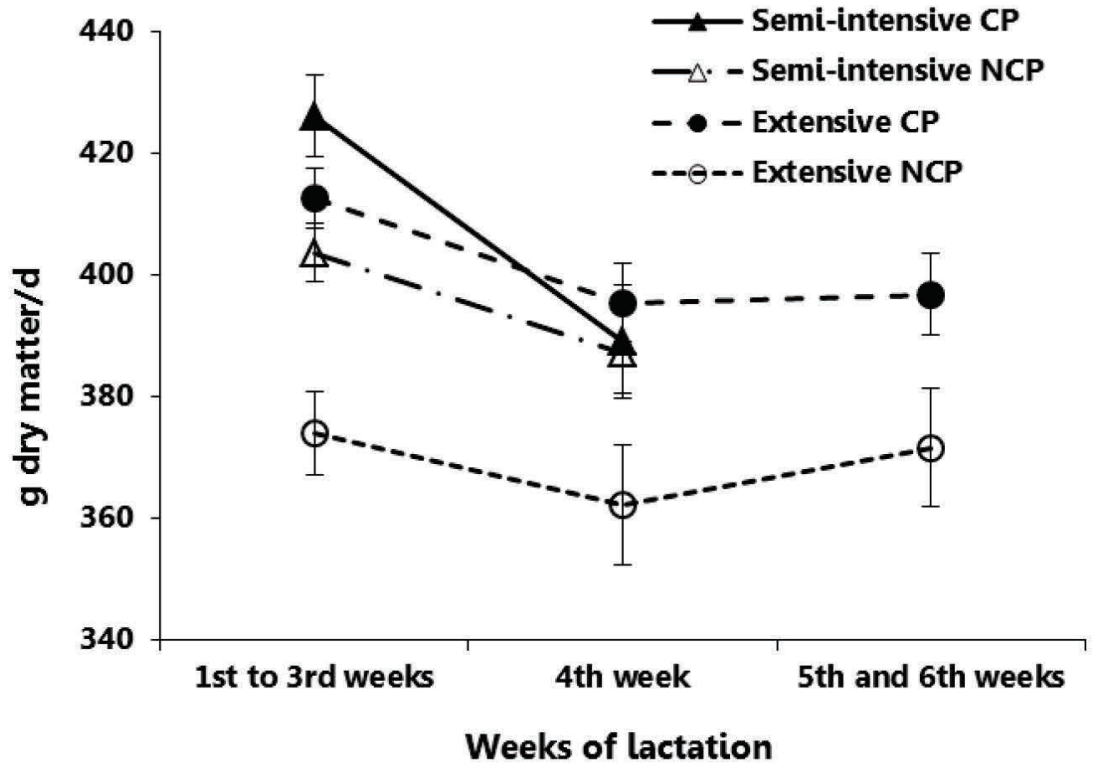

Figure 3. Feed intake of lactating multiparous rabbit does according to the concurrence of pregnancy and previous lactation. Semiintensive reproductive system: insemination at $11^{\text {th }}$ day postpartum (dpp) and weaning at $28^{\text {th }} \mathrm{dpp}$; extensive reproductive system: insemination at $25^{\text {th }}$ dpp and weaning at $42^{\text {nd }} d p p$. $\mathrm{CP}$ : concurrence of pregnancy and previous lactation; NCP: no concurrence of pregnancy and previous lactation. 
Table 6. Effect of the feeding system (FS) and the reproductive system (RS) on litters of multiparous rabbit does

\begin{tabular}{|c|c|c|c|c|c|c|c|}
\hline & \multicolumn{4}{|c|}{ Group $^{1}$} & \multicolumn{2}{|c|}{$\begin{array}{c}\text { Contrast }^{2} \\
\text { (estimate } \pm \text { standard error) }\end{array}$} & \multirow[t]{2}{*}{ Interactions $^{3}$} \\
\hline & $\mathrm{C} 28$ & C42 & E28 & E42 & FS & RS & \\
\hline Number of observations $s^{4}$ & $196(46)$ & $198(45)$ & $194(43)$ & $174(45)$ & & & \\
\hline \multicolumn{8}{|l|}{ At birth } \\
\hline Total litter size & $11.89 \pm 0.34^{\mathrm{ab}}$ & $12.45 \pm 0.34^{\mathrm{a}}$ & $11.78 \pm 0.33^{\mathrm{ab}}$ & $11.30 \pm 0.36^{\mathrm{b}}$ & $-0.63 \pm 0.34$ & $0.04 \pm 0.34$ & \\
\hline Total litter weight $(\mathrm{g})$ & $700 \pm 15^{\mathrm{a}}$ & $691 \pm 15^{\mathrm{ab}}$ & $698 \pm 14^{\mathrm{ab}}$ & $658 \pm 15^{\mathrm{b}}$ & $-18 \pm 15$ & $-25 \pm 15$ & $\mathrm{RS} \times \mathrm{PO}^{* *}$ \\
\hline \multicolumn{8}{|l|}{ At $28^{\text {th }}$ day of lactation 5} \\
\hline Litter size & $9.84 \pm 0.10$ & $9.90 \pm 0.10$ & $9.63 \pm 0.10$ & $9.91 \pm 0.10$ & $-0.11 \pm 0.10$ & $0.17 \pm 0.10$ & \\
\hline Individual live weight (g) & $589 \pm 8^{a}$ & $564 \pm 8^{b}$ & $515 \pm 8^{c}$ & $506 \pm 8^{c}$ & $-66 \pm 8^{* \star \star}$ & $-16 \pm 8^{*}$ & $\mathrm{RS} \times \mathrm{PO}^{* *}$ \\
\hline Individual feed intake (g DM/d) ${ }^{6}$ & $7.0 \pm 0.3^{a}$ & $6.6 \pm 0.3^{a}$ & $4.7 \pm 0.3^{b}$ & $4.6 \pm 0.3^{b}$ & $-2.1 \pm 0.3^{\star \star \star}$ & $-0.2 \pm 0.3$ & \\
\hline \multicolumn{8}{|l|}{ At $42^{\text {th }}$ day of lactation ${ }^{5}$} \\
\hline Litter size & & $9.60 \pm 0.15$ & & $9.12 \pm 0.16$ & $-0.48 \pm 0.21^{*}$ & & \\
\hline Individual live weight (g) & & $1150 \pm 12$ & & $1086 \pm 12$ & $-64 \pm 17^{\star \star \star}$ & & \\
\hline Individual feed intake (g DM/d) ${ }^{6}$ & & $79.0 \pm 1.8$ & & $73.6 \pm 1.9$ & $-5.3 \pm 2.6^{*}$ & & \\
\hline 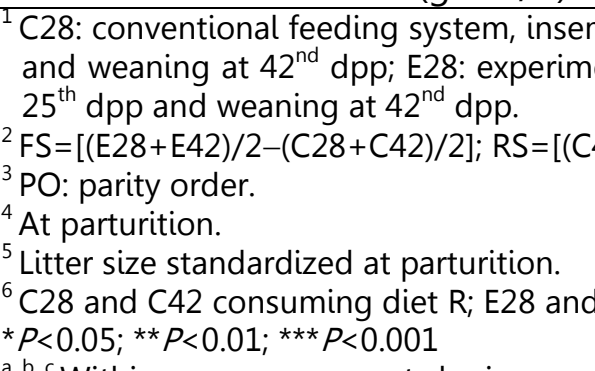 & $\begin{array}{l}\text { ination at } 11^{\text {th }} \text { da) } \\
\text { tal feeding syste } \\
2+E 42) / 2-(C 28+E\end{array}$ & $\begin{array}{l}\text { post-partum (d } \\
\text { n, insemination } \\
8) / 2] \text {. }\end{array}$ & $\begin{array}{l}\text { p) and weaning a } \\
\text { t } 11^{\text {th }} d p p \text { and } w\end{array}$ & $\begin{array}{l}28^{\text {th }} \text { dpp; } C 42: c \\
\text { aning at } 28^{\text {th }} \text { dp }\end{array}$ & $\begin{array}{l}\text { onventional feed } \\
\text { p; E42: experime }\end{array}$ & $\begin{array}{l}\text { system, insemi } \\
\text { feeding systen }\end{array}$ & $\begin{array}{l}\text { ation at } 25^{\text {th }} \mathrm{dpp} \\
\text { insemination at }\end{array}$ \\
\hline
\end{tabular}


Milk yield from parturition to $18^{\text {th }}$ dpp was lower in rabbit does under the experimental FS (-5.1\%), mainly because of differences between E28 and C28 $(-17 \pm 6 \mathrm{~g} / \mathrm{d}, P=0.006)$. Moreover, an interaction $\mathrm{FS} \times \mathrm{RS} \times \mathrm{PO}$ was detected, as shown in Figure 4 ( $a$ and $b$ ). In rabbit does under semi-intensive RS, milk yield was very similar with both FS in the $2^{\text {nd }}$ and $3^{\text {rd }}$ lactations and afterwards it increased with the conventional FS and not with the experimental FS, resulting significantly lower for this latter in the $4^{\text {th }}$ and $5^{\text {th }}$ lactations $(-27 \pm 8 \mathrm{~g} / \mathrm{d}$, $P=0.001$ ); in rabbit does under extensive RS, milk yield increased in the $3^{\text {rd }}$ and $4^{\text {th }}$ lactations with the conventional FS whereas it was similar from $2^{\text {nd }}$ to $5^{\text {th }}$ lactations with the experimental FS, resulting significantly lower for this latter in the $3^{\text {rd }}$ and $4^{\text {th }}$ lactations $(-17 \pm 7 \mathrm{~g} / \mathrm{d}, P=0.018)$. Previous lactationpregnancy concurrence increased milk yield from parturition to $18^{\text {th }} \mathrm{dpp}$ in rabbit does under extensive RS $(+13 \pm 4 \mathrm{~g} / \mathrm{d}, P<0.001)$ but not in those under semi-intensive RS. During the $4^{\text {th }}$ week of lactation, milk yield varied as described for the previous period, being lower with experimental FS (-4.7\%) and with differences between C28 and E28 being close to significance ( $P=0.069)$; the evolution through the successive cycles followed the pattern above illustrated, milk yield being lower in E28 than in C28 for the $4^{\text {th }}$ and $5^{\text {th }}$ lactations $(-28 \pm 12 \mathrm{~g} / \mathrm{d}, P=0.018)$ and in E42 than in C42 for the $3^{\text {rd }}$ and $4^{\text {th }}$ lactations $(-24 \pm 11 \mathrm{~g} / \mathrm{d}, P=0.027)$. No differences were observed in milk yield during the two last weeks of lactation between C42 and E42.

The effect of FS on live weight change of rabbit does from parturition to weaning depended on the RS; thus, E28 showed a higher live weight increase than C28 (+90 $\pm 41 \mathrm{~g}, P=0.031)$, whereas no significant difference was observed between C42 and E42. Live weight increase from weaning to next parturition was higher in the extensive than in the semi-intensive RS. Figure 5 shows the effect of RS on live weight change of rabbit does between consecutive parturitions in the successive cycles. No differences were found at the $2^{\text {nd }}$ and $3^{\text {rd }}$ cycles, whereas lower increases were observed in rabbit does under extensive RS in the $4^{\text {th }}$ and $5^{\text {th }}$ cycles $(-123 \pm 37 \mathrm{~g}, P<0.001)$. 

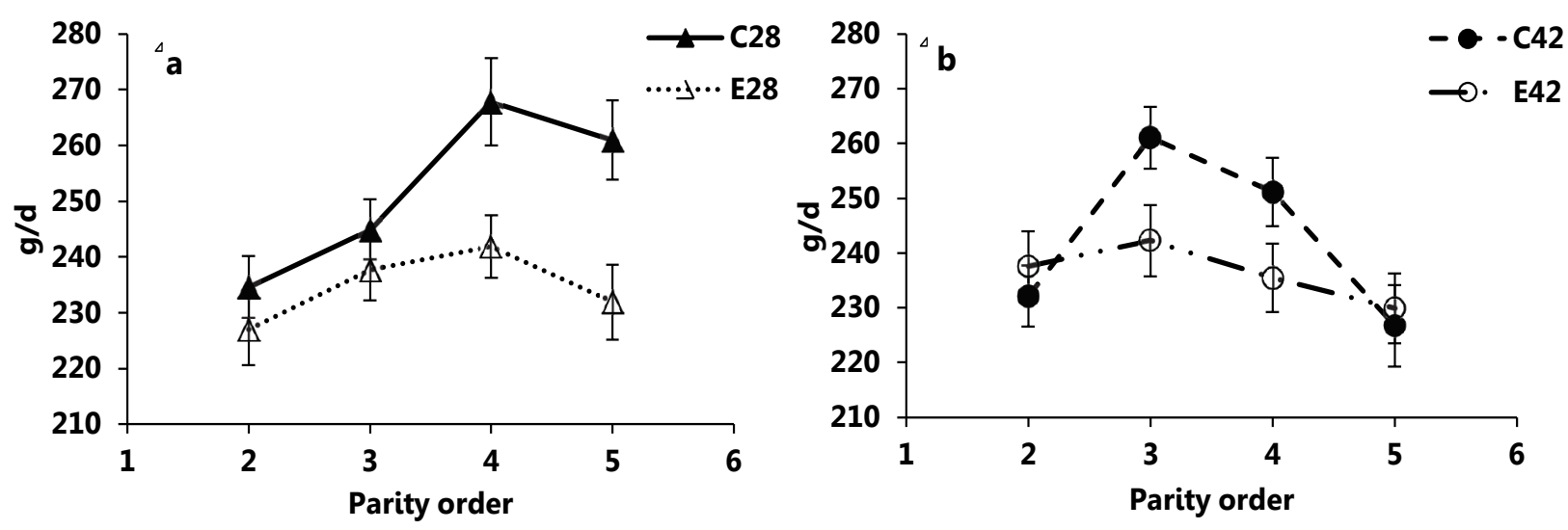

Figure 4. Milk yield from parturition to $18^{\text {th }}$ day post-partum (dpp) in successive cycles in multiparous rabbit does under semi-intensive (a) or extensive (b) reproductive system. C28: conventional feeding system (FS), insemination at $11^{\text {th }} \mathrm{dpp}$ and weaning at $28^{\text {th }} \mathrm{dpp}$; E28: experimental FS, insemination at $11^{\text {th }} \mathrm{dpp}$ and weaning at $28^{\text {th }}$ dpp; C42: conventional FS, insemination at $25^{\text {th }} \mathrm{dpp}$ and weaning at $42^{\text {nd }} \mathrm{dpp}$; E42: experimental FS, insemination at $25^{\text {th }} d p p$ and weaning at $42^{\text {nd }} d p p$.

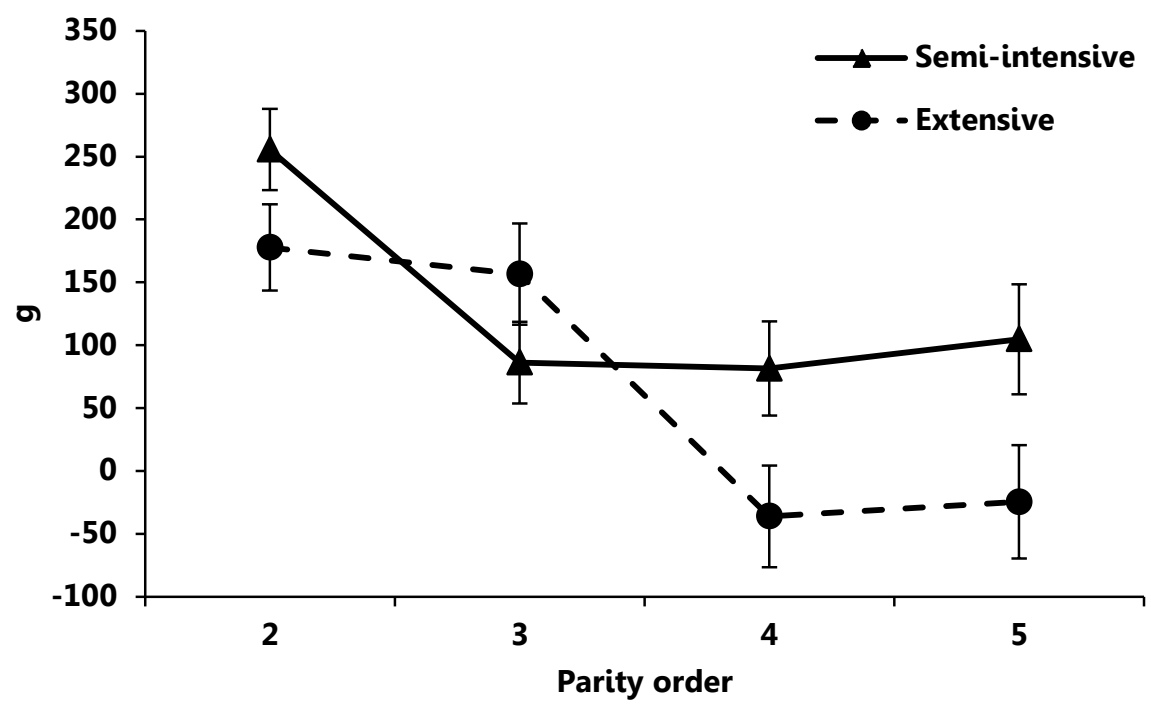

Figure 5. Live weight change of multiparous rabbit does from parturition to next parturition in the successive cycles. Semi-intensive reproductive system: insemination at $11^{\text {th }}$ day post-partum (dpp) and weaning at $28^{\text {th }} \mathrm{dpp}$; extensive reproductive system: insemination at $25^{\text {th }} \mathrm{dpp}$ and weaning at $42^{\text {nd }} \mathrm{dpp}$.

Litter size at birth was lower in E42 than in C42 $(-1.15 \pm 0.49, P=0.022)$. The effect of RS on litter weight at birth was close to significance $(P=0.096)$ and an interaction between RS and PO was detected (Figure 6a). Litter weight at birth was very similar for both $\mathrm{RS}$ at the $2^{\text {nd }}$ and $3^{\text {rd }}$ parturitions and 
afterwards it decreased in the extensive RS, resulting significantly lower at the $4^{\text {th }}, 5^{\text {th }}$ and $6^{\text {th }}$ parturitions $(-61 \pm 19 \mathrm{~g}, P=0.001)$. No differences in mortality of kits at birth were observed depending on FS but it was lower in the extensive than in the semi-intensive RS ( $7.5 \mathrm{vs} .9 .6 \%, P<0.001)$; the individual live weight of kits at birth was lower in the extensive than in the semi-intensive RS $(-3.0 \pm 1.2 \mathrm{~g}, P=0.013)$.
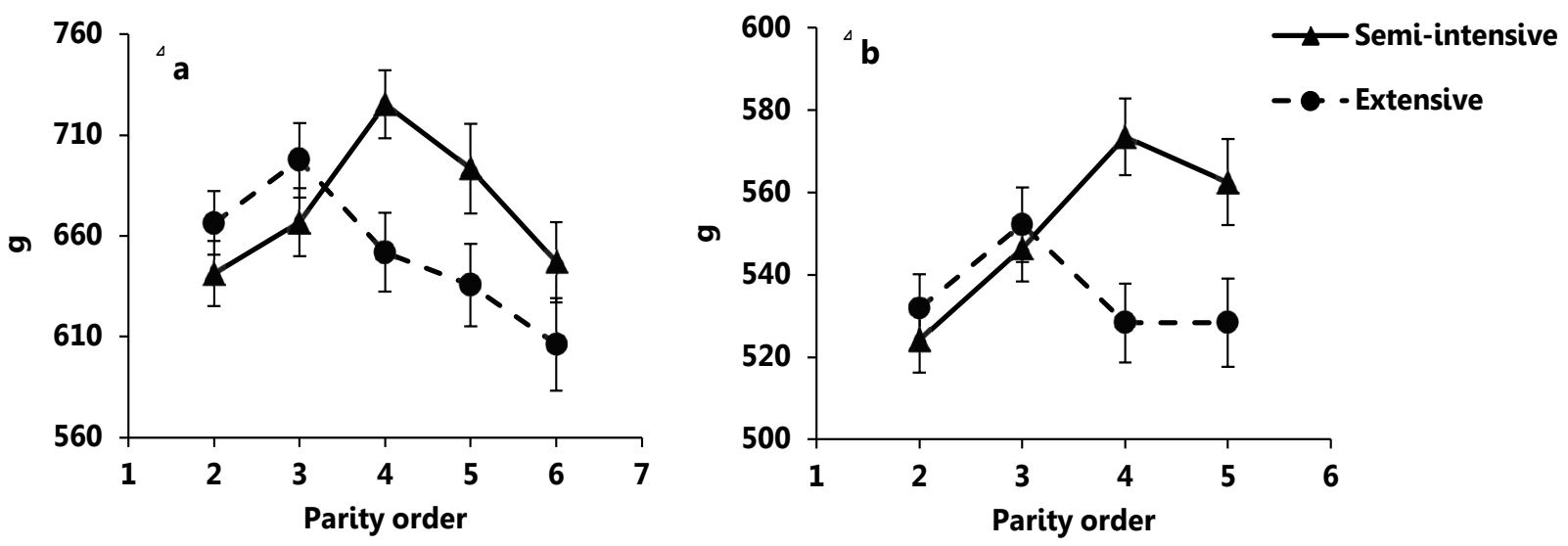

Figure 6. Total litter weight at birth (a) and individual live weight of young rabbits at 28 days of age (b) in the successive cycles. Semi-intensive reproductive system: insemination at $11^{\text {th }}$ day post-partum (dpp) and weaning at $28^{\text {th }} \mathrm{dpp}$; extensive reproductive system: insemination at $25^{\text {th }} \mathrm{dpp}$ and weaning at $42^{\text {nd }} \mathrm{dpp}$.

Mortality rate until $28^{\text {th }} \mathrm{dpp}$ averaged $6.4 \%$ with no differences depending on FS or RS and, consequently, litter size at $28^{\text {th }}$ dpp was similar in all groups. However, live weight of young rabbits was lower with the experimental FS $(-11 \%)$. On the other hand, live weight of young rabbits was lower in C42 than in C28 $(-25 \pm 12 \mathrm{~g}, P=0.036)$. Moreover, the effect of RS varied depending on the PO (Figure $6 b$ ), since live weight of young rabbits was similar for both RS at the $2^{\text {nd }}$ and $3^{\text {rd }}$ cycles but lower in the extensive RS for the $4^{\text {th }}$ and $5^{\text {th }}$ lactations $(-40 \pm 11, P<0.001)$. Feed intake of litters was reduced in the experimental FS (-31\%). Litter size, live weight of young rabbits and feed intake at $42^{\text {nd }}$ dpp were lower in E42 than in C42 $(-5.0,-5.3$ and $-6.7 \%$, respectively). 
Table 7. Effect of the feeding system (FS) and the reproductive system (RS) on mortality rate of growing rabbits

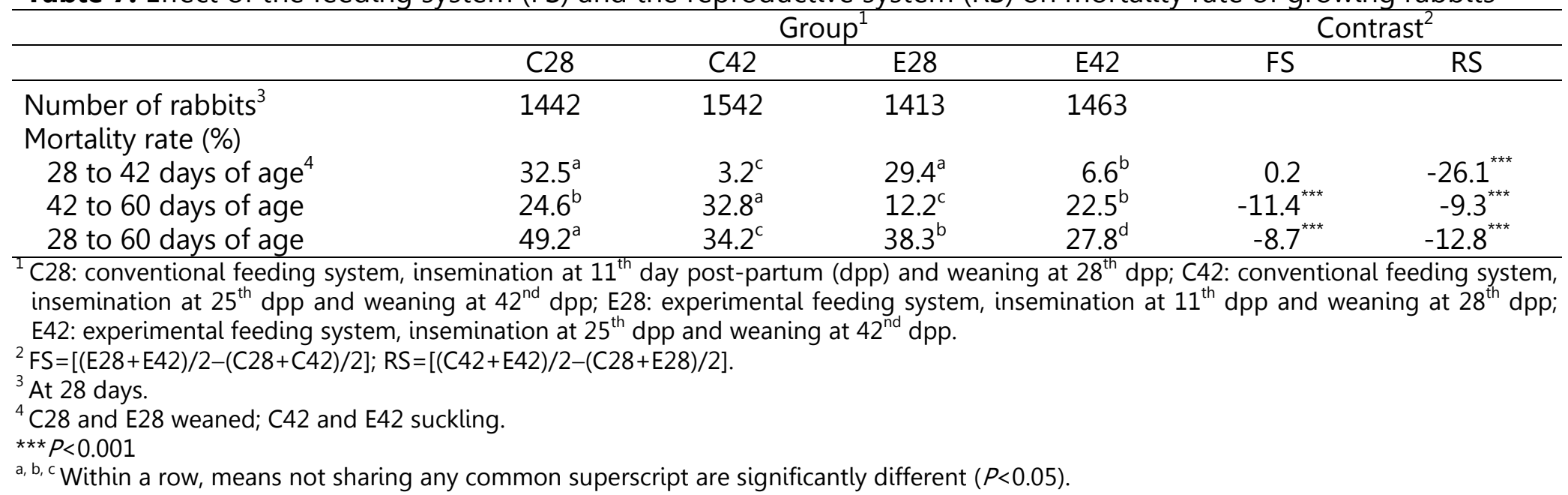


Culling rate of females and mortality of young rabbits from 28 to 60 days

Culling rate (by death, disease or reproductive failure) of rabbit does was higher in E42 than in the rest of groups (47.8 vs. 30.1\%, $P=0.029)$.

Mortality rate of young rabbits is presented in Table 7 and Figure 7. There was a reduction in mortality rate from 28 to 42 days of age in the extensive RS (-26.1\%); moreover, it was lower in C42 than in E42 $(-3.4 \%$, $P<0.001)$; on the contrary, mortality rate during the same period was lower in E28 than in C28 $(-3.1 \%, P=0.077)$. From 42 to 60 days of age, lower mortality rate was recorded with experimental FS $(-11.4 \%)$ and the semi-intensive RS $(-9.3 \%)$. The accumulated mortality at 60 days of age was reduced with both experimental FS and extensive RS ( $-8.7 \%$ and $-12.8 \%$, respectively). On the other hand, Figure 8 shows the evolution of accumulated mortality at 60 days of age through the successive cycles depending on the FS; with the experimental FS, mortality rate was similar for the five cycles (averaging $33.0 \%)$ whereas in the conventional FS it was very high in the two first cycles and decreased progressively until the last cycle (from 50.5 to $25.4 \%, P<0.001$ ).

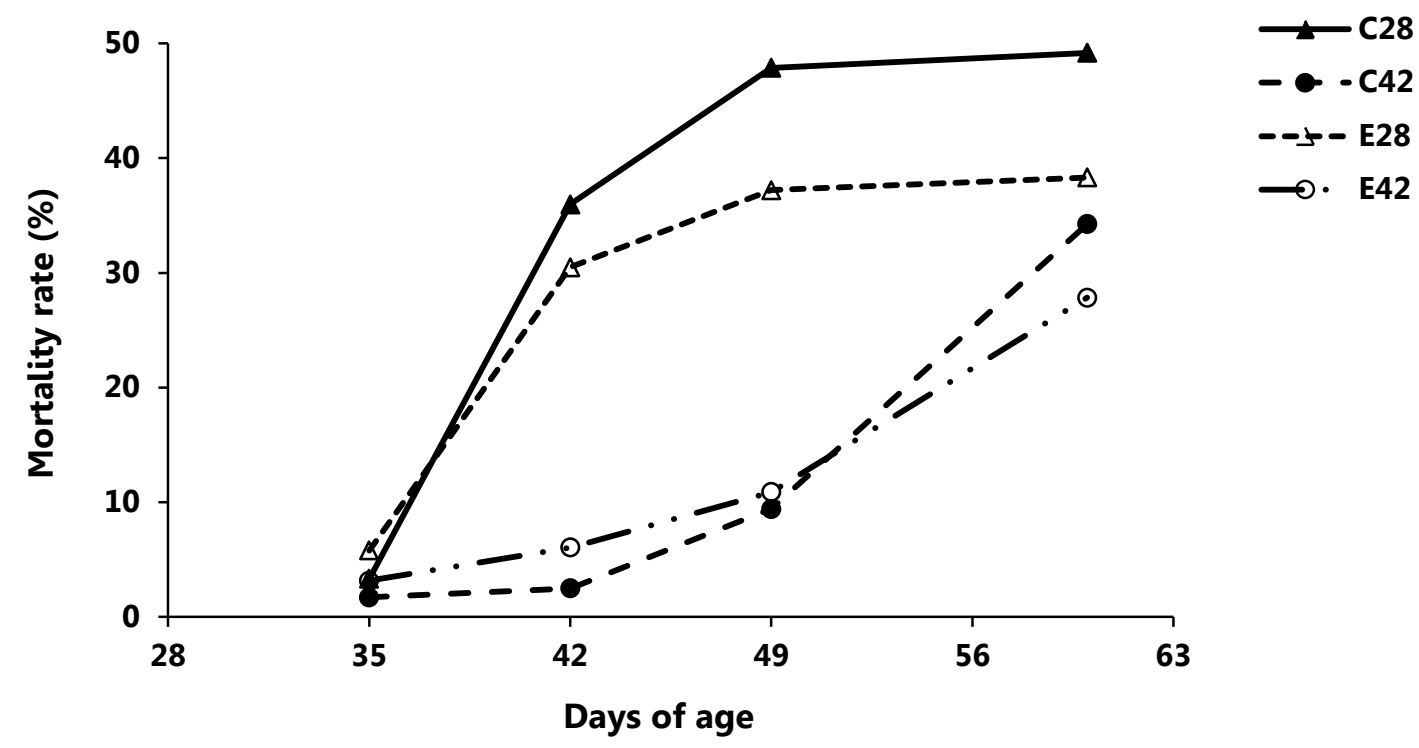

Figure 7. Accumulated mortality rate since 28 to 60 days of age of growing rabbits in the four experimental groups. C28: conventional feeding system (FS) and weaning at $28^{\text {th }}$ dpp; E28: experimental FS weaning at $28^{\text {th }} \mathrm{dpp}$; C42: conventional FS and weaning at $42^{\text {nd }}$ dpp; E42: experimental FS and weaning at $42^{\text {nd }} \mathrm{dpp}$. 


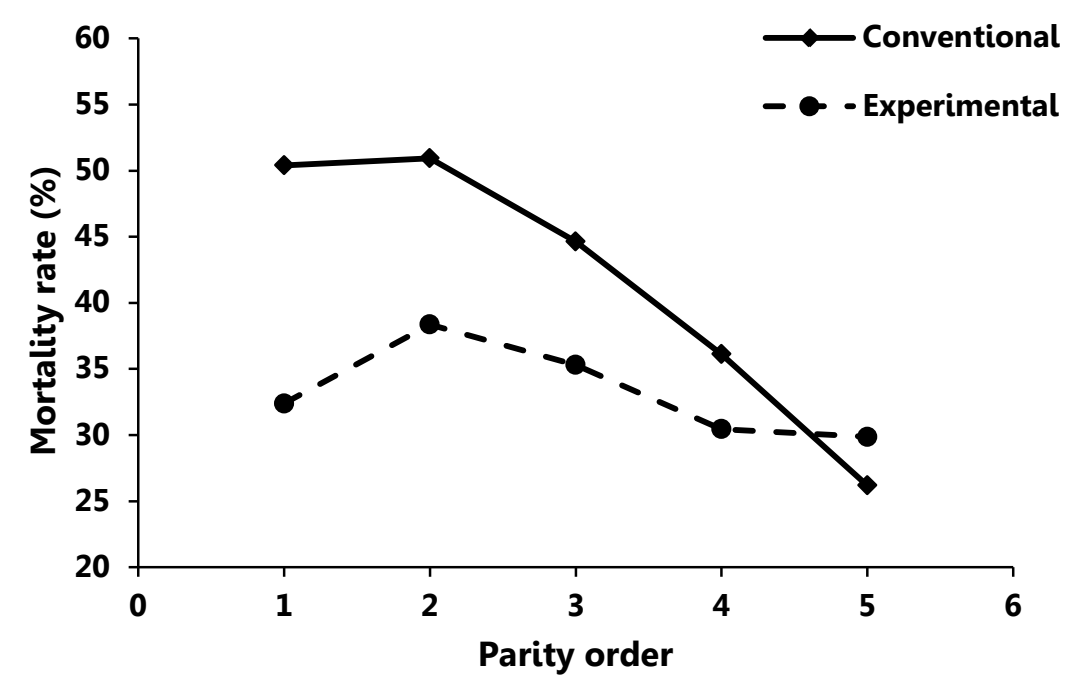

Figure 8. Mortality rate of growing rabbits since 28 to 60 days of age in the successive cycles in the two feeding systems.

\section{Discussion}

\section{Effects on rabbit does}

Previous exposure and training seem to determine the response of animals when confronting an environmental challenge, such as a less nutrient availability than required (Roche et al., 2009; Savietto et al., 2011). In the current study, the consumption of a less concentrated diet by rabbit does from the $18^{\text {th }} \mathrm{dpp}$ until weaning through five successive cycles did not affect feed intake during the first part of lactation (when consuming a concentrated reproduction diet) but led to lower milk yield during this period. However, the evolution of differences in milk yield through the successive cycles were diverse depending on RS; the impairment of milk yield appeared in the $4^{\text {th }}$ lactation in rabbit does under semi-intensive RS, whereas it was earlier $\left(3^{\text {rd }}\right.$ lactation) in those under extensive RS. This fact could be explained by an adaptation of the animals when resources availability was limited in order to preserve body condition (PFT change from parturition to insemination was similar in experimental than in conventional FS independently of the reproductive rhythm: $+0.059 \pm 0.085 \mathrm{~mm}$ and $+0.041 \pm 0.085 \mathrm{~mm}, N S$, respectively for insemination at $11^{\text {th }}$ or $25^{\text {th }} \mathrm{dpp}$ ) and prioritize the 
reproductive career of females (Pascual, 2010); this adaptation would be faster when more intense or longer was the restriction of resources, as occurred when the differentiated feeding lasted 24 days instead of only 10 days.

Feed intake increased when rabbit does received the less concentrated diet, which allowed them to reach similar milk yield than those continuously receiving the concentrated reproduction diet in $5^{\text {th }}$ and $6^{\text {th }}$ weeks of lactation, when milk yield is at lower level, as reported by Fernández-Carmona et al. (1995) for the two last weeks of lactation when weaning at $35^{\text {th }}$ dpp. However, this fact was not so clear in the $4^{\text {th }}$ week of lactation, probably because of the possible negative effect of the dietary switching on feed intake, especially if taking into account that animals showed very lower preference for diet $\mathrm{E}$ respect to diet $\mathrm{R}$ in a choice test (Cervera et al., 2010). Moreover, in this week primiparous and multiparous does behaved differently. In primiparous does inseminated at $11^{\text {th }} \mathrm{dpp}$, feed intake was similar for both diets, which implies lower energy availability for the animals fed with diet $E$, explaining the reduction of milk yield and the negative effect on body condition in pregnant rabbit does (PFT change from insemination to weaning impaired with the less concentrated diet: $-0.487 \pm 0.153 \mathrm{~mm}, P=0.002$ ). In primiparous does inseminated at $25^{\text {th }} \mathrm{dpp}$, milk yield during the $4^{\text {th }}$ week of lactation was unaffected by the FS, but the degree of adaptation to the dietary switching seemed to determine the reproductive response, since those animals being able to increase feed intake when receiving the less concentrated diet became pregnant at the end of this week, overcoming the nutritional challenge and ensuring the next litter (Friggens, 2003; Savietto et al., 2011). This fact would explain why the delay of the insemination failed in improving fertility in primiparous rabbit does when supplying the less concentrated diet, contrary to what occurred when using the more concentrated commercial reproduction diet, as usually reported (Feugier and Fortun-Lamothe, 2006). In multiparous rabbit does milk yield during this $4^{\text {th }}$ week of lactation followed the pattern above described for the first part of lactation; however, those under semiintensive RS showed similar feed intake for both diets whereas those under 
extensive RS were able to anticipate the increase of the consumption of the less concentrated diet, showing similar body condition change from parturition to weaning than those receiving the more concentrated diet. This fact would be also related with the above mentioned longer exposure to nutritional challenge; this hypothesis would be also supported by concurrence of pregnancy and lactation in the previous cycle increasing feed intake during lactation in greater and longer extent in rabbit does under extensive RS, when the differentiated feeding lasted 24 days instead of only 10 days in those under semi-intensive RS.

Martínez-Vallespín et al. (2011) reported that multiparous rabbit does fed on high fibre-low starch diets from $18^{\text {th }}$ to $28^{\text {th }} \mathrm{dpp}$ (weaning), increased feed intake and reduced milk yield as in the current study but impaired their body condition at weaning, probably because in this case rabbit does were not allocated to the same experimental treatment in the successive cycles and behaved similarly to the primiparous does of the current study. In fact, primiparous lactating does receiving the less concentrated diet for longer time (i.e. submitted to the most adverse conditions with no previous training) showed worse body condition at the $2^{\text {nd }}$ parturition than the rest of primiparous does despite their higher feed intake during the $2^{\text {nd }}$ pregnancy. On the contrary, multiparous rabbit does exposed to the most adverse conditions were able to add a new adaptive response as reducing the pregnancy load $(-38 \pm 17 \mathrm{~g}, P=0.030)$.

The delay of the weaning implies more physiological effort for rabbit does; it did not affect negatively feed intake, milk yield, live weight and body condition during the first 3 cycles. However, a process of adaptation seems to occur in the following cycles, involving a clear reduction of feed intake, milk yield and live weight increase (live weight at the $6^{\text {th }}$ parturition was lower in rabbit does under extensive than under semi-intensive RS: $-178 \pm 61 \mathrm{~g}$, $P=0.004)$ but preserving body condition. In fact, PFT sharply decreased from $1^{\text {st }}$ to $3^{\text {rd }}$ parturition $(-0.381 \pm 0.058 \mathrm{~mm}, P<0.001)$ and remained similar 
between $4^{\text {th }}$ and $6^{\text {th }}$ parturition $(+0.042 \pm 0.067 \mathrm{~mm}, N S)$, regardless of the RS. Nevertheless, rabbit does under the most adverse conditions (experimental FS and extensive RS) registered the highest culling rate which could mean that the ability to confront simultaneously a nutritional challenge and higher physiological effort is limited and could lead them to physiological exhaustion.

On the other hand, the extensive RS reduced the mortality of kits at birth, despite their lower individual live weight $(-3.0 \pm 1.2 \mathrm{~g}, P=0.013)$; lower incidence of hypoglycaemia in pre-partum can be hypothesized to explain this finding.

\section{Effects on young rabbits}

Growth rate of suckling rabbits reflects the negative effects of experimental FS on both milk yield and feed intake of young rabbits, also observed by Martínez-Vallespín et al. (2011) when using high fibre-low starch diets in combined feeding of females and young rabbits. On the other hand, mortality rate of young rabbits until $28^{\text {th }} \mathrm{dpp}$ was unaffected by FS or RS; however, both factors had clear effect onwards. Thus, low mortality rate was recorded in suckling rabbits from 28 to 42 days of age, whereas very high mortality rate was recorded during this period in weaned rabbits. This fact would confirm the protective role of rabbit milk (Gallois et al. 2007); under this protection, a less concentrated weaning diet would have a negative effect on health of young rabbits, by lower nutrient supply via both milk and feed. However, this protection was transitory and without it, a less concentrated weaning diet revealed as more favourable for digestive health in a context of ERE, in agreement with results obtained by Martínez-Vallespín et al. (2011). This effect seems to be related to beneficial changes in caecal environment (Martínez-Vallespín et al., see Experiment $\|$ in the present thesis) and, consequently, would be independent of the PO. Under the conventional FS, mortality rate sharply decreased with the $\mathrm{PO}$; taking into account that Quevedo et al. (2003) found that $50 \%$ of mortality rate observed during the 
growing period came from $22 \%$ of the females, it could be an indicator of an improvement of the general health status of the females related with the culling of more vulnerable animals, which would point out an additional interest of the robustness and productive longevity in females (Pascual, 2010).

\section{Conclusion}

The negative effects of using a less concentrated weaning diet in combined feeding of females and young rabbits and of delaying both insemination (from $11^{\text {th }}$ to $25^{\text {th }} \mathrm{dpp}$ ) and weaning (from $28^{\text {th }}$ to $42^{\text {nd }} \mathrm{dpp}$ ) on performance of rabbit does could illustrate an adaptation process to limited availability of resources and to greater physiological effort because of longer lactations; on the contrary, both strategies were beneficial for digestive health of growing rabbits.

Acknowledgements: Financial support was provided by the Spanish Ministerio de Educación y Ciencia (ProyectoAGL2006-07596).

\section{References}

AOAC, 2000. Official methods of analysis of the AOAC International, $17^{\text {th }}$ ed., AOAC International, Gaithersburg, MD (USA).

Batey, I.L., 1982. Starch analysis using thermostable alpha-amylases. Starch/Stärke 34, 125-128.

Boletín Oficial del Estado, 2005. Real Decreto 1201/2005 sobre protección de los animales utilizados para experimentación y otros fines científicos. BOE 242, 34367-34391.

Cervera, C., Soler, C., Ródenas, L., Martínez-Paredes, E., Fernández, C., Pascual, J.J., Blas, E. 2010. Feeding preferences of rabbit does and young rabbits. Proc. $4^{\circ}$ Congreso Cunicultura de las Américas, Córdoba (Argentina).

Fernández-Carmona, J., Cervera, C., Sabater, C., Blas, E., 1995. Effect of diet composition on the production of rabbit breeding does housed in a traditional building and at $30^{\circ} \mathrm{C}$. Anim. Feed Sci. Technol. 52, 289-297. 
Fernández-Carmona, J., Blas, E., Pascual, J.J., Maertens, L., Gidenne, T., Xiccato, G., García, J., 2005. Recommendations and guidelines for applied nutrition experiments in rabbits. World Rabbit Sci. 13, 209-228.

Feugier, A., Fortun-Lamothe, L., 2006. Extensive reproductive rhythm and early weaning improve body condition and fertility of rabbit does. Anim. Res. $55,459-470$.

Friggens, N.C., 2003. Body lipid reserves and the reproductive cycle: towards a better understanding. Livest. Prod. Sci. 83, 219-236.

Fundación Española para el Desarrollo de la Nutrición Animal, 2010. Tablas FEDNA de composición y valor nutritivo de alimentos para la fabricación de piensos compuestos, $3^{a}$ ed., De Blas, C., Mateos, G.G., García-Rebollar, P. (coord.). FEDNA, Madrid (Spain).

Gallois, M., Gidenne, G., Tasca, C., Caubert, C., Coudert, C., Milon, A., Boullier, S., 2007. Maternal milk contains antimicrobial factors thath protect young rabbits from enteropathogenic Escherichia coli infection. Clin. Vaccine Immunol. 14, 585-592.

Gidenne, T., Fortun-Lamothe, L., 2002. Feeding strategy for young rabbit around weaning: a review of digestive capacity and nutritional needs. Anim. Sci. 75, 169-184.

Gidenne, T., García, J., Lebas, F., Licois, D., 2010. Nutrition and feeding strategy: interactions with pathology. In: De Blas, C., Wiseman, J. (Eds.), Nutrition of the Rabbit, $2^{\text {nd }}$ ed., CAB International, Wallingford (UK), pp. 179-199.

Hall, M.B., Lewis, B.A., Van Soest, P.J., Chase, L.E., 1997. A simple method for estimation of neutral detergent-soluble fibre. J. Sci. Food Agric. 74, 441449.

Le Bouquin, S., Jobert, J.L., Larour, G., Balaine, L., Eono, F., Boucher, S., Huneau, A., Michel, V., 2009. Risk factors for an acute expression of Epizootic Rabbit Enteropathy syndrome in rabbits after weaning in French kindling-to-finish farms. Livest. Sci. 125, 283-290. 
Littell, R.C., Henry, P.R., Ammerman, C.B., 1998. Statistical analysis of repeated measures data using SAS procedures. J. Anim. Sci. 76, 1216-1231.

Martínez-Vallespín, B., Martínez-Paredes, E., Ródenas, L., Cervera, C., Pascual, J.J., Blas, E., 2011. Combined feeding of rabbit female and young: partial replacement of starch with acid detergent fibre or/and neutral detergent soluble fibre at two protein levels. Livest. Sci. 141, 155-165.

Pascual, J.J., 2010. The role of body condition on new feeding and breeding programmes for reproductive rabbits does. Proc. $22^{\text {nd }}$ Hungary Conference on Rabbit Production, Kaposvar (Hungary), 25 pp.

Pascual, J.J., Castella, F., Cervera, C., Blas, E., Fernández-Carmona, J., 2000. The use of ultrasound measurements of perirenal fat thickness to estimate changes in body condition of young female rabbits. Anim. Sci. 70, 435442.

Pascual, J.J., Cervera, C., Blas, E., Fernández-Carmona, J., 2003. High energy diets for reproductive rabbit does: effect of energy source. Nutr. Abstr. Rev. Series B: Livestock Feeds and Feeding 73 (5), 27R-39R.

Quevedo, F., Pascual, J.J., Blas, E., Cervera, C., 2003. Influencia de la madre sobre el crecimiento y la mortalidad de los gazapos en cebo. Proc. XXVIII Symposium de Cunicultura (ASESCU), Alcañiz (Spain), 115-122.

Roche, J.R., Friggens, N.C., Kay, J.K., Fisher, M.W., Stafford, K.J., Berry, D.P., 2009. Invited review: Body condition score and its association with dairy cow productivity, health, and welfare. J. Dairy Sci. 92, 5769-5801.

Rosell, J.M., de la Fuente, L.F., Badiola, J.I., Fernández de Luco, D., Casal, J., Saco, M., 2009. Study of urgent visits to commercial rabbit farms in Spain and Portugal during 1997-2007. World Rabbit Sci. 17, 127-136.

Savietto, D., Cervera, C., Blas, E., Baselga, M., Larsen, T., Friggens, N.C., Pascual, J.J., 2011. Are selection for reproduction or foundation for longevity affecting rabbit females robustness? 1. Nutritional challenge. Animal (submitted). 
Statistical Analysis Systems Institute, 2002. User's guide, Release 9.1. SAS Institute Inc, Cary, NC (USA).

Van Soest, P.J., Robertson, J.R., Lewis, B.A., 1991. Methods for dietary fiber, neutral detergent fiber and nonstarch polysaccharides in relation to animal nutrition. J. Dairy Sci. 74, 3583-3597.

Villamide, M.J., Maertens, L., De Blas C., 2010. Feed evaluation. In: De Blas, C., Wiseman, J. (Eds.), Nutrition of the Rabbit, $2^{\text {nd }}$ ed., CAB International, Wallingford (UK), pp. 151-162.

Xiccato, G., Trocino, A., Sartori, A., Queaque, P.I., 2004. Effect of parity order and litter weaning age on the performance and body energy balance of rabbit does. Livest. Prod. Sci. 85, 239-251. 



\section{GENERAL CONCLUSION}

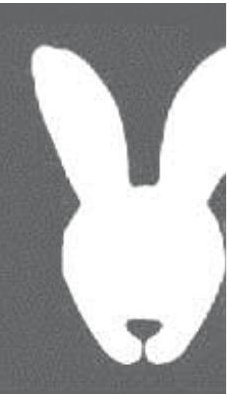



The combined feeding by using a weaning diet for rabbit females in late lactation and young rabbits around weaning has been hypothesized as an approach to promote suitable development of hindgut and digestive health during the growing period, particularly in a context of Epizootic Rabbit Enteropathy (ERE), but its effects on performance and body condition of females must be also taken into account.

In the first study of the current thesis eight weaning diets were tested, the results showing that partial replacement of starch with ADF or/and with NDSF or/and the reduction of CP content from 175 to $145 \mathrm{~g} / \mathrm{kg}$ DM impaired milk yield and body condition of rabbit does at weaning, as well as the litter weight at weaning and the growth rate during the post-weaning period; however, in an ERE context, mortality rate during this period was reduced by these three dietary changes, which effects seemed additive.

The impact of the above mentioned dietary changes on the caecal environment of growing rabbit was evaluated in the second study, which revealed them promoting a caecal environment more favourable for digestive health, mainly by higher VFA concentration and lower ammonia concentration.

Finally, the third study dealt with the long term effects of using a less concentrated weaning diet and of delaying both insemination and weaning on the performance and body condition of females and on the mortality of young rabbits. The negative effects of the less concentrated diet and of delaying both insemination and weaning on performance of rabbit does could illustrate an adaptation process to limited availability of resources and to greater physiological effort because of longer lactations; on the other hand, both strategies reduced mortality rate of growing rabbits in an ERE context. 



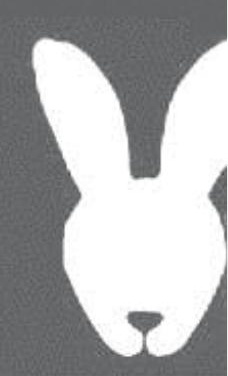



The Epizootic Rabbit Enteropathy (ERE) has high prevalence and incidence in the field conditions, compromising severely the efficiency and competitiveness of rabbit production. Its aetiology remains unknown and no specific prophylaxis and treatment are available, although antibiotics are usually effective in reducing morbidity and mortality rates. Besides, much research work has been performed in the last decade to limit ERE with nutritional approaches.

The results of this thesis show that both the use of less concentrated weaning diets and the delay of weaning age reduce mortality rate of growing rabbits in a context of ERE. Nevertheless, even considering this reduction and despite using zinc bacitracin, the registered mortality rates were clearly higher to the acceptable ones in a rational and viable rabbit production system, which means that those strategies should be considered as a way of reducing the risk of ERE and not of fighting it effectively.

On the other hand, the advantage of using a less concentrated weaning diet for reducing mortality rate seems disappear when growing rabbits are under the transitory protective effect of the maternal milk, since in this case lower mortality rate was observed when they consumed the more concentrated standard diet for rabbit does; this fact illustrates how ERE could be interfering with the progress in knowledge on nutrition for optimising growth and health of young rabbits. Moreover, both the consumption of less concentrated weaning diets and the delay of weaning impaired performance of rabbit does.

Consequently, it seems advisable to intensify the research work on differentiated feeding systems of females and young rabbits, including the development of weaning diets that can emulate the protective effect of the maternal milk. 
